\title{
DIVERSITY AND FUNCTION OF ROOT-ASSOCIATED FUNGAL COMMUNITIES IN RELATION TO NITROGEN NUTRITION IN TEMPERATE FORESTS
}

\author{
Dissertation
}

In Partial Fulfillment of the Requirements for the Degree of Doctor of Philosophy (PhD) of the Faculty of Forest Sciences and Forest Ecology, Georg-August-University of Göttingen, Germany

\author{
Submitted by \\ Quang Dung Nguyen \\ Born in Hanoi, Vietnam
}

Göttingen, 2018 
Referee: $\quad$ Prof. Dr. Andrea Polle

Co-referee: Prof. Dr. Konstantin V. Krutovsky

Date of examination: 18 July 2018 


\section{Table of Contents}

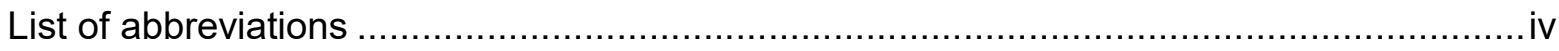

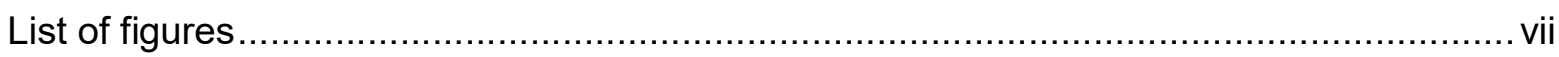

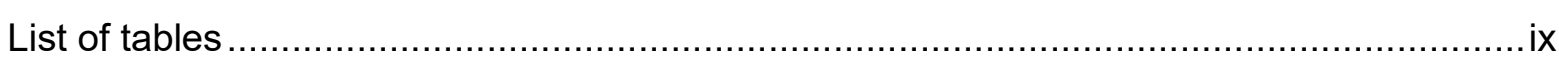

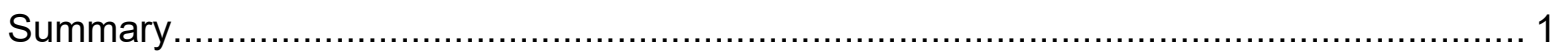

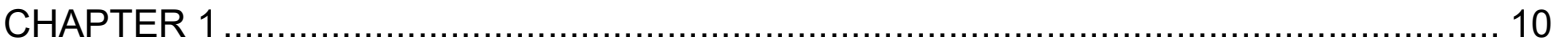

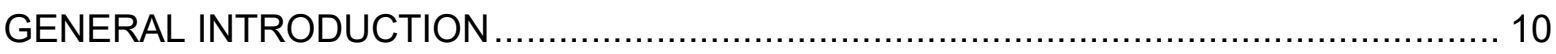

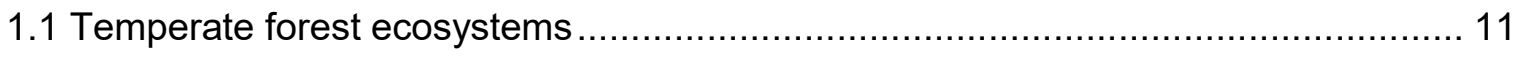

1.2 Climate change and its effects on temperate forests ..................................... 12

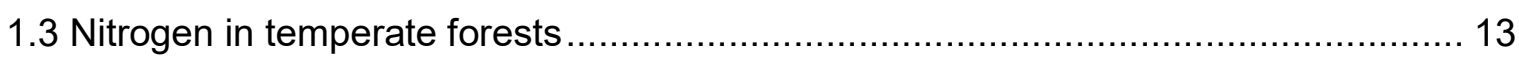

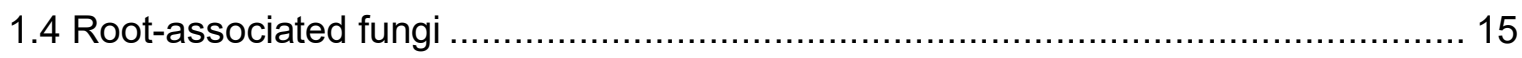

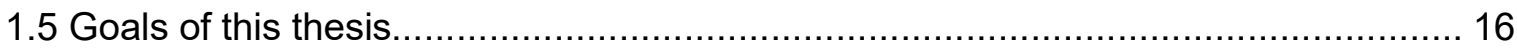

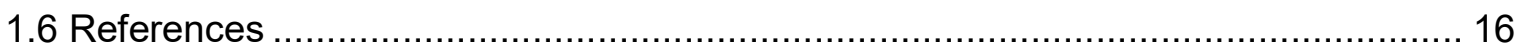

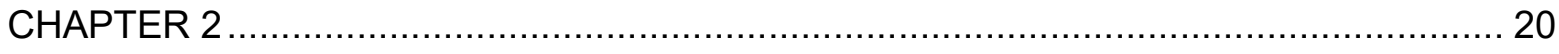

IMPACT OF ECTOMYCORRHIZAL COMMUNITY COMPOSITION AND SOIL

TREATMENT ON INORGANIC NITROGEN NUTRITION AND PERFORMANCE OF

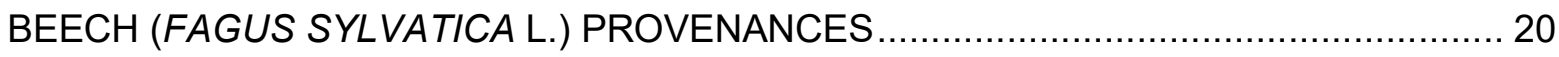

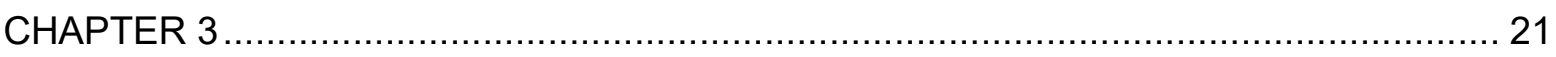

BEECH AND FUNGAL TRANSCRIPTOMES IN RESPONSE ............................... 21

TO DIFFERENT BIOGEOGRAPHICAL ENVIRONMENTS IN TEMPERATE FORESTS ... 21

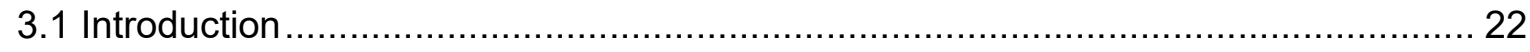

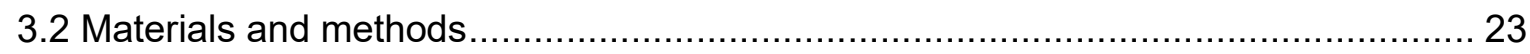

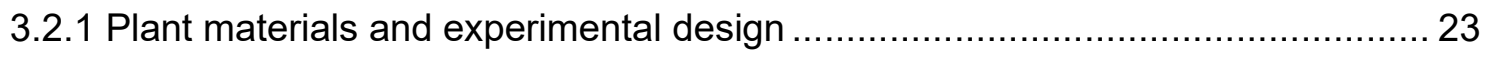

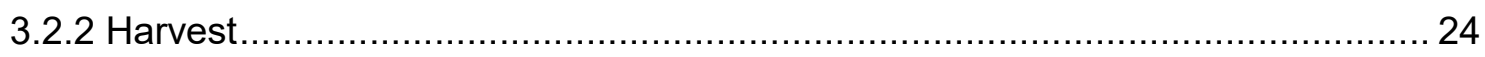

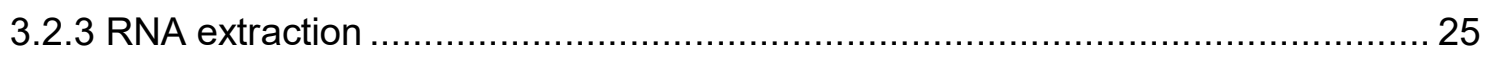

3.2.4 Library preparation and RNA sequencing .......................................... 27

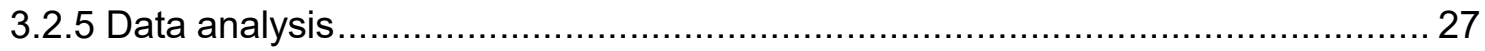

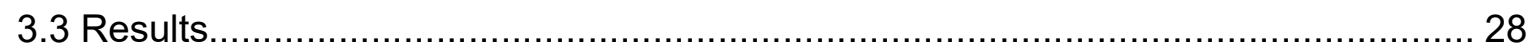

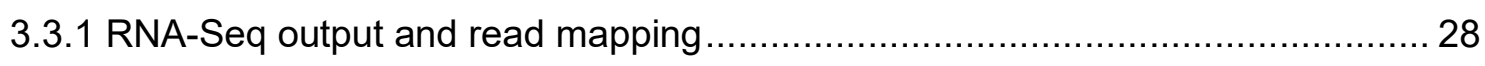

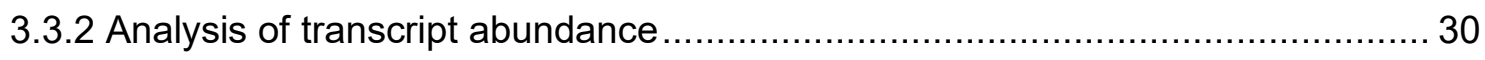

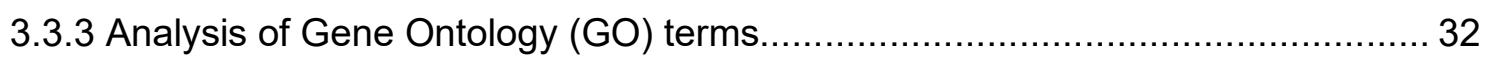

3.3.4 Beech and fungal genes related to nitrogen uptake and assimilation................ 34

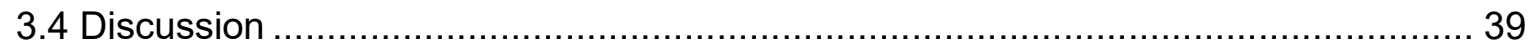

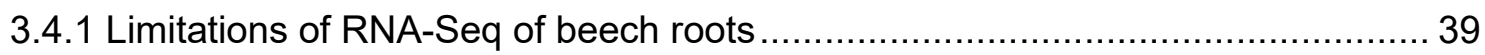

3.4.2 Differentially expressed genes of beech in three biogeographical regions ......... 40 
3.4.3 N-related genes of beech and fungi

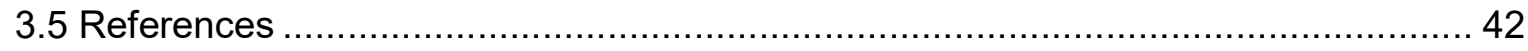

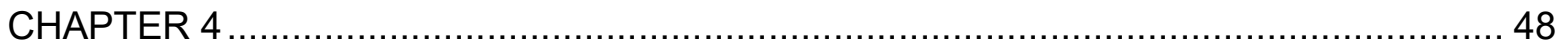

ROOT-ASSOCIATED FUNGAL COMMUNITIES AND THEIR RELATIONSHIPS WITH

SOIL AND ROOT NITROGEN AND CARBON AVAILABILITY IN TEMPERATE FORESTS

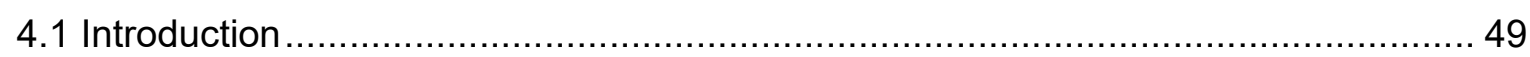

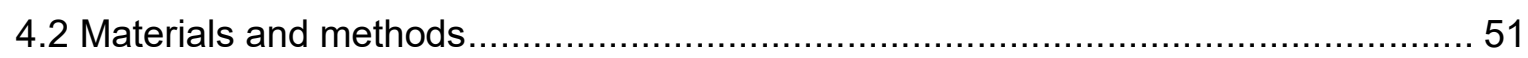

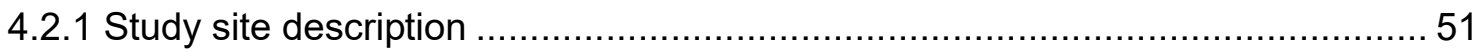

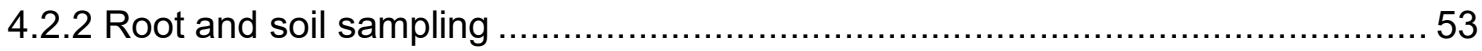

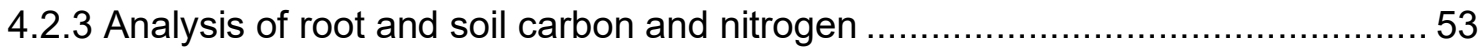

4.2.4 Analysis of non-structural carbohydrates ..................................................... 53

4.2.5 Analysis of soil and root ammonium and nitrate......................................... 54

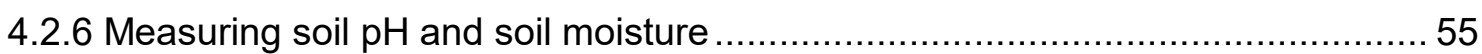

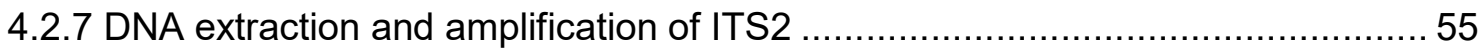

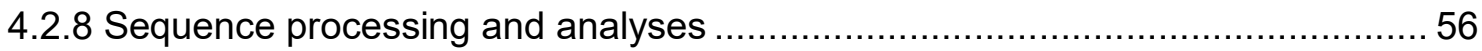

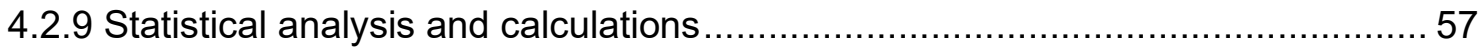

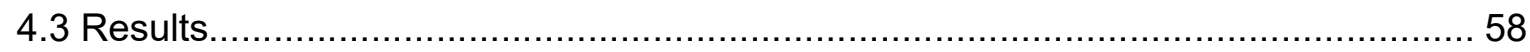

4.3.1 Soil and root chemistry varies among biogeographic regions ......................... 58

4.3.2 Characterization of the abundance and richness of root-associated fungi ......... 60

4.3.3 Taxonomic and trophic community structures of root-associated fungi ...............62 62

4.3.4 Drivers for the changes in root-associated fungal communities in three

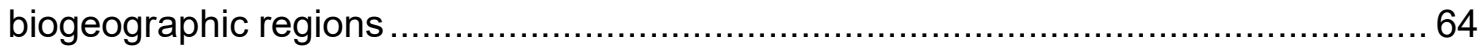

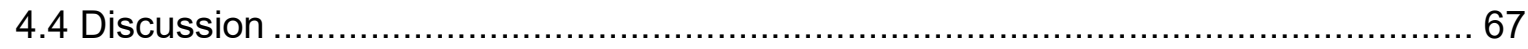

4.4.1 Differentiation in taxonomic and trophic communities of root-associated

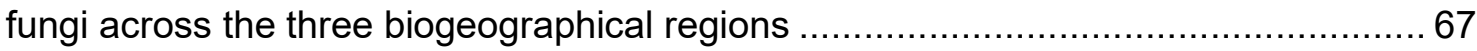

4.4.2 Root and soil factors correlated with trophic and taxonomic groups of root-

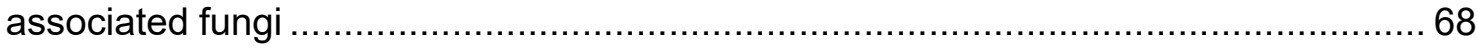

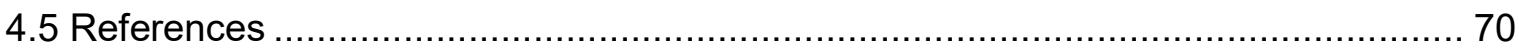

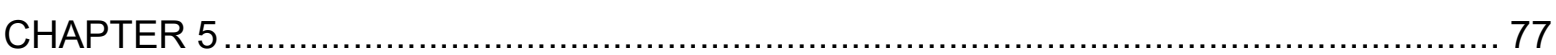

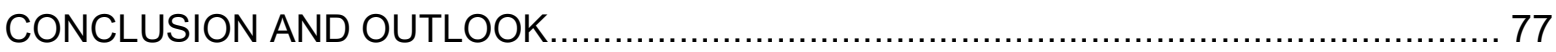

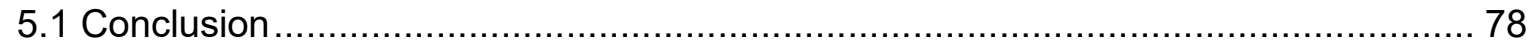

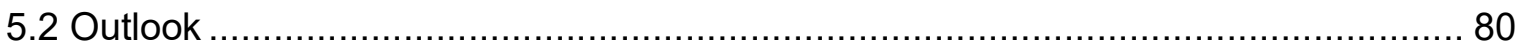

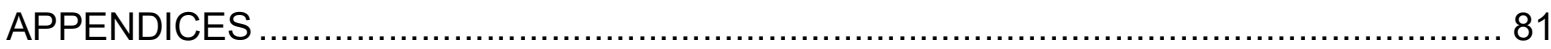

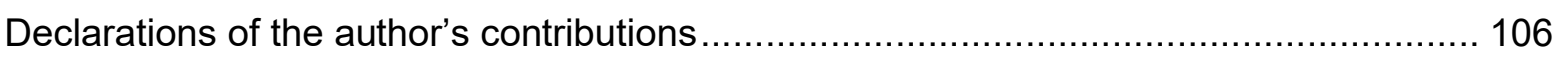

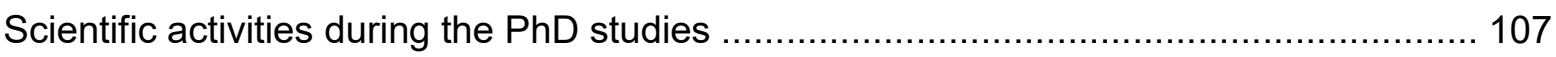

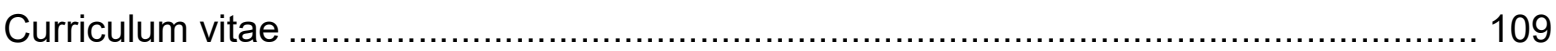


Declaration of originality and certificate of authorship 


\section{List of abbreviations}

15Am

15Am_R_S

$15 \mathrm{Ni}$

15Ni_R_S

A

AGI

AIC

ANOSIM

ANOVA

BM

BTE

C

Cege

DEG

DFG

DNA

dNTPs

EC

EEA

$\mathrm{E}_{H}$

EM

EMF

et al.

Fasyl

g

g

GLM

GO

$\mathrm{H}$

$\mathrm{H}^{\prime}$

Hein

IPCC whole plant ${ }^{15} \mathrm{~N}$ content after labeling with ${ }^{15} \mathrm{NH}_{4}^{+}$

relative aboveground allocation of plant ${ }^{15} \mathrm{~N}$ after labeling with

ammonium

whole plant ${ }^{15} \mathrm{~N}$ content after labeling with ${ }^{15} \mathrm{NO}_{3}{ }^{-}$

relative aboveground allocation of plant ${ }^{15} \mathrm{~N}$ after lableling with nitrate

Schwäbische Alb

arabidopsis genome initiative

Akaike's information criterion

Analyses of similarity

analysis of variance

whole plant biomass

beech transplantation experiment

carbon

Cenococcum geophilum

differentially expressed genes

German Research Foundation

deoxyribonucleic acid

deoxynucleotide

enzyme commission

European Environment Agency

species evenness

ectomycorrhiza

ectomycorrhizal fungi

and others (et alii)

Fagus sylvatica L.

gram

relative centrifugal force

general linear model

gene ontology

Hainich-Dün

Shannon diversity index

Hebeloma incarnatulum

Intergovernmental Panel on Climate Change 
ITS

KEGG

KOG

I

m

M

$\min$

MMN

n

$\mathrm{N}$

NMDS

NoMy

O

${ }^{\circ} \mathrm{C}$

OD

OTU

$\mathrm{p}$

PAT

PCA

PCR

$\mathrm{pH}$

PPFD

PS

R_S

RAF

RIN

RNA

RNA Seq

RT

$S$

SAP

sec

SEM

SYM

$\mathrm{T}$ internal transcribed spacer

Kyoto Encyclopedia of Genes and Genomes

eucaryotic orthologous groups of protein

litre

metre

molar

minute

modified Melin-Norkrans

number of replicates

whole plant nitrogen

non-metric multidimentaional scaling

non-mycorrhizal root tips

original Hanich-Dün forest soil

degree Celsius

optical density

operational taxonomic unit

probability of error

pathotroph

principal component analysis

polymerase chain reaction

negative log of the activity of the hydrogen ion

photosynthetic photon flux density

photosynthesis

root-to-shoot ratio

root-associated fungal or fungi

RNA integrity number

ribonucleic acid

ribonucleic acid sequencing

root tip

Schorfheide-Chorin

saprotroph

second

standard error of means

symbiotroph

the original Hainich-Dün forest soil which was sterilized and amended 
with soil bacteria

Tosu

Tomentella sublilacima

Turu

Tuber rufum

VIF

variance inflation factor 


\section{List of figures}

Fig. 1.1 Global distribution of temperate forests. Green colour indicates the temperate forests. Source: http://www.ducksters.com .

Fig. 1.2 Global spatial patterns of total inorganic nitrogen deposition .......................14

Fig. 3.1 Beech Transplantation Experiment...................................................... 24

Fig. 3.2 Assessment of RNA intensity isolated from roots of beech seedlings by electrophoretic analysis

Fig. 3.3 Principal component analysis (PCA) for transcript abundance from three different biogeographical regions.

Fig. 3.4 Numbers of differently expressed genes (DEGs) of beech (a) and Venn diagrams for beech DEGs in pairwise comparison (b) among the three biogeographic regions

Fig. 3.5 Hierarchy of enriched GO terms of DEGs in relation to biological processes between $\mathrm{H}$ and $\mathrm{S}$ regions

Fig. 3.6 Nitrogen metabolism of beech. Red colours indicate beech genes involved in nitrogen metabolism

Fig. 3.7 Nitrogen metabolism of fungi. Red colour indicates fungal genes involved in nitrogen metabolism

Fig. 4.1 NMDS plots by OTU taxonomic (a) and trophic (b) composition of root associated fungal communities of 150 forest plots in three regions based on Bray-Curtis dissimilarity matrix

Fig. 4.2 Relative abundance of root-associated fungal communities in three study regions. The abundance of trophic groups (a), blue=symbiotroph, red=saprotroph, green=pathotroph, purple=unknown. The OTU taxonomic orders (b), fungal orders with a relative abundance

Fig. 4.3 Significant relationships between the abundance of trophic groups and soil or root chemistry (a) and relative importance of abiotic variables to trophic fungal groups (b) in the three biogeographical regions.

Fig. 4.4 Significant relationships between the abundance of root-associated fungal orders and soil and root chemistry (a) and relative importance of abiotic variables to taxonomic fungal orders (b) in the three study regions

Appendix Fig. 3.1 Hierarchy of enriched GO terms of DEGs between $\mathrm{H}$ and $\mathrm{S}$ regions. Enriched GO terms were coded green, while white color indicate GO terms which were not enriched.

Appendix Fig. 3.2 Nitrogen metabolism of beech. Red colours indicate beech genes involved in nitrogen metabolism

Appendix Fig. 3.3 Nitrogen metabolism of Laccaria bicolor. Red colour indicates fungal genes involved in nitrogen metabolism

Appendix Fig. 4.1 Correlation between soil moisture and annual mean temperature in forest plots across Germany in 2014 
Appendix Fig. 4.2 Rarefaction curves depicting the fungal operational taxonomic unit (OTU) richness in 50 forest plots for each study region

Appendix Fig. 4.3 Significant relationships between soil and root chemistry and the read abundance of root-associated trophic groups in the three study regions .....102

Appendix Fig. 4.4 Mean abundance of dead root tips per plot $(n=30)$ in the three biogeographical regions 


\section{List of tables}

Table 3.1 Summary of numbers of reads after RNA sequencing of twelve samples from three biogeographical regions

Table 3.2 Summary of results of mapping transcriptomic data of 12 samples against transcriptomes of Fagus sylvatica and 27 ectomycorrhizal fungi .....

Table 3.3 N-related genes in the beech transcriptome. These genes obtained from mapping the beech transcriptome against $\mathrm{N}$ metabolism and from doing keyword search for nitratre and ammonium transporters using the beech transcriptome

Table 3.4 N-related genes in the fungal transcriptome. These genes obtained from mapping the fungal transcriptome against $\mathrm{N}$ metabolism and from doing keyword search for nitratre and ammonium transporters using the fungal transcriptome

Table 4.1 Key biogeographic characteristics of three study regions.....

Table 4.2 Characterization of soil and root carbon and nitrogen, soil $\mathrm{pH}$ and soil moisture in three biogeographical regions.

Table 4.3 Operational taxonomic unit (OTU) richness and diversity estimates of root-associated fungi in three biogeographical regions

Table 4.4 Similarity of root-associated fungal communities according to OTU taxonomic and trophic composition, symbiotroph (SYM), saprotroph (SAP) and pathotroph (PAT) among the three biogeographical regions.

Appendix Table 3.1 Field experimental plots where beech nuts were collected, the seedlings were planted out, harvested and used for RNA Seq

Appendix Table 3.2 A list of ectomycorrjizal fungi which is associated with beech and commonly observed in temperate forests for mapping fungal transcriptomic data.

Appendix Table 3.3 N-related beech "genes" which belong to GO:0010243 and GO:0051171.

Appendix Table 3.4 N-related genes in the beech transcriptome. These genes obtained from mapping the transcriptome against $\mathrm{N}$ metabolism and from doing keyword search for nitrate and ammonium transporters using the beech transcriptome

Appendix Table 3.5 N-related genes in the fungal transcriptome. These genes obtained from mapping the fungal transcriptome against $\mathrm{N}$ metabolism and from doing keyword search for nitrate and ammonium transporters using the fungal transcriptome

Appendix Table 3.6 Common genes to $\mathrm{A}$ and $\mathrm{H}$ among differentially expressed genes

Appendix Table 4.1 Mean read abundance and OTU richness of rootassociated fungal trophic groups in three biogeographic regions.

Appendix Table 4.2 Characterization and statistical analyses of mean relative abundance of fungal orders per plot in three biogeographical regions.... 


\section{Summary}

Ectomycorrhizal fungi form symbiotic association with roots of a variety of plant species. They provide plants with nutrients in exchange of photosynthetic carbohydrates. In natural ecosystems, plants form associations not only with ectomycorrhizal fungi but also with a variety of other microbes. Interest in rootassociated fungal communities is increasing because they may play an important role in plant nutrition and fitness. Nitrogen $(\mathrm{N})$ is an essential nutrient for plant growth and development but often a limiting factor in forest ecosystems. To date, little is known on the relationship of root-associated fungi with their environmental conditions and their potential function for tree $\mathrm{N}$ nutrition. Therefore, this study was designed to investigate environmental drivers and functions of root-associated fungal communities in relation to N.

Here, beech (Fagus sylvatica L.) was selected as a host plant to investigate the contribution of ectomycorrhizal fungi to plant $\mathrm{N}$ supply. Furthermore, this study used the infrastructure of the Biodiversity Exploratories which includes 150 forest plots $(100 \times 100 \mathrm{~m})$ across three biogeographic regions of 422 to $1300 \mathrm{~km}^{2}$, Schwäbische Alb, Hainich-Dün and Schorfheide-Chorin located along a transect about $700 \mathrm{~km}$ across Germany. The Biodiversity Exploratories provide a well-organized platform for largescale and long-term research on functional biodiversity in response to land use and geographical regions. A beech transplantation experiment, where young beeches of provenances from different Exploratory plots were grown side-by-side in the three research regions, was also used.

The objectives of this study were (1) to assess the impact of ectomycorrhizal diversity and community composition on inorganic $\mathrm{N}$ nutrition and performance of beech provenances, (2) to obtain insights into molecular mechanisms of ectomycorrhizal fungi-beech interactions, (3) to investigate root-associated fungal communities and their relationships with soil and root $\mathrm{N}$ and carbon in temperate forests.

(1) To assess the impact of ectomycorrhizal community composition and soil treatment on inorganic $\mathrm{N}$ nutrition and beech performance, I hypothesized: (i) the performance and $\mathrm{N}$ nutrition of beech provenances differ in a common environment; (ii) the performance and $\mathrm{N}$ nutrition of beech provenances differ with different ectomycorrhizal community compositions; and (iii) beech provenances from the three biogeographical areas prefer the $\mathrm{N}$ form that is prevalent in their natural environment. To test these 
hypotheses, a greenhouse experiment was set up with three beech provenances grown from beech nuts. Diversity of ectomycorrhizal fungi was manipulated by planting beech seedlings in two soil types: original forest Hainich-Dün soil and Hainich-Dün soil which was sterilized and reinoculated with bacteria. After two years of exposure, I measured beech performance, identified EMF communities and investigated beech $\mathrm{N}$ nutrition by tracing ${ }^{15} \mathrm{~N}$ labelled $\mathrm{NH}_{4}{ }^{+}$and $\mathrm{NO}_{3}{ }^{-}$. The effects of soil and provenance and their interaction were analysed using general linear models. Analysis of similarity of ectomycorrhizal communities between soil treatments and among provenances were applied. Canonical correspondence analysis was conducted to explore the relationships among plant biomass, nitrogen and ectomycorrhizal communities. In contrast to my expectation, genetically determined effects on growth, nitrogen content and ${ }^{15} \mathrm{~N}$ uptake were not detected. Improved performance and long-term $\mathrm{N}$ nutrition were observed for the beech provenances grown in original soil colonized by higher ectomycorrhizal diversity than for those in treated soil. However, increased ectomycorrhizal fungi diversity did not affect beech ${ }^{15} \mathrm{~N}$ uptake. Different beech provenances preferred $\mathrm{NO}_{3}^{-}$over $\mathrm{NH}_{4}^{+}$. Overall, the results suggest that beech performance and $\mathrm{N}$ nutrition are controlled by soil microbes, in particular, by the ectomycorrhizal community composition.

(2) To obtain insights into molecular mechanisms of ectomycorrhizal fungi-beech interaction, beech and fungal transcriptomes were characterized, and the response of fungal and beech gene transcript levels to differences in environmental conditions were investigated. Young beech plants from the provenance "Schorfheide-Chorin" were planted in the three biogeographical regions of the Exploratories. After two years of growth under field conditions, beech roots were harvested and used to study transcriptomes. After quality filtering, cleaned sequences were mapped against transcriptomes of beech and ectomycorrhizal fungi. Transcripts with significantly decreased or increased abundance among the three regions were detected. The patterns of transcript abundance among the three regions were visualized by principal component analysis. Gene ontology term analysis was applied to detect possible functions of differentially expressed genes. The transcriptome of Schorfheide-Chorin was different from those from the other two regions. Most differentially expressed genes and enriched gene ontology terms were detected between Hainich-Dün and Schorfheide-Chorin. Beech genes (111) and ectomycorrhizal genes (374), which were related to $\mathrm{N}$ uptake and assimilation, were identified. The detected beech genes were 
involved in nitrate uptake and assimilation, whereas fungal genes contributed to ammonium uptake and assimilation.

(3) To investigate the diversity and community composition of root-associated fungal communities and their interrelationship with soil and root nitrogen and carbon availability in temperate forests, the following hypotheses were tested: (i) the taxonomic community compositions differ among different biogeographical regions, but the trophic community compositions are similar; (ii) Root-associated fungal communities are driven more strongly by root than by soil chemistry because of the tight interaction of fungal communities with host plants; and (iii) different ecological groups of the root-associated fungi (symbiotroph, saprotroph and pathotroph) respond differently to environmental variation in soil and root $\mathrm{N}$ and carbon. To test these hypotheses, fine roots were sampled from 150 forest plots in the three Exploratory regions and related to root and soil chemistry. Root-associated fungi were identified by Illumina sequencing (MiSeq) and related to root and soil chemistry. Root-associated fungal community composition was explored using non-metric multidimensional scaling and analysis of similarities. Relationships between the abundance of root-associated fungi and abiotic variables were investigated using linear mixed effects models. Taxonomic community composition differed significantly among the three regions which was expected, but the difference in the taxonomic community composition was stronger than that in the trophic community composition which differed moderately between Schorfheide-Chorin and the two other regions but did not differ between Schwäbische-Alb and HainichDün. Trophic fungal groups (symbiotroph, saprotroph and pathotroph) were driven by root $\mathrm{NH}_{4}^{+}$and $\mathrm{NO}_{3}^{-}$, and $\mathrm{N}$ and carbon in roots were more important than those elements in soil for changes in the fungal groups. The abundance of fungal orders present in our analysis was driven by root $\mathrm{NO}_{3}{ }^{-}$. In agreement with my expectation, different fungal orders exhibited distinct patterns with the abiotic variables. Overall, these results support that functional resilience might be achieved by taxonomic divergence between Schwäbische Alb and Hainich-Dün. Biogeographical region and $\mathrm{N}$ in roots $\left(\mathrm{NH}_{4}{ }^{+}\right.$and $\left.\mathrm{NO}_{3}{ }^{-}\right)$were drivers for changes in the abundance of root-associated fungal communities.

In conclusion, this study provides insights into the relationships between rootassociated fungi and nitrogen in temperate forests. In young beech trees, ectomycorrhizal diversity controls $\mathrm{N}$ nutrition. How this works at the molecular levels remained enigmatic because $\mathrm{NO}_{3}{ }^{-}$was the preferred $\mathrm{N}$ source for beech underpinned by beech gene expression, while fungal genes were related to $\mathrm{NH}_{4}^{+}$uptake and 
assimilation. Biogeographical regions and $\mathrm{N}$-related variables $\left(\mathrm{NO}_{3}{ }^{-}, \mathrm{NH}_{4}{ }^{+}\right)$in roots are drivers for changes in root-associated fungal community composition across temperate forests. Future research should address taxon-specific fungal $\mathrm{N}$ uptake and the temporal dynamics of root-associated fungal communities. Developing a reference genome for Fagus sylvatica would be an important basis for better understanding the molecular mechanisms for beech-fungal interactions. 


\section{Zusammenfassung}

Ektomykorrhizapilze bilden Symbiosen mit den Wurzeln vieler Pflanzenarten aus. Sie versorgen die Pflanzen mit Nährstoffen und werden im Gegenzug von den Pflanzen mit Kohlenhydraten aus der Photosynthese versorgt. In natürlichen Ökosystemen bilden Pflanzenwurzeln nicht nur mit Ektomykorrhizapilzen, sondern auch mit einer Vielzahl anderer Mikroben Interaktionen aus. Das Interesse an wurzelassoziierten Pilzgemeinschaften wächst, da diese eine wichtige Rolle bei der Nährstoffversorgung und Fitness der Pflanzen spielen könnten. Stickstoff $(N)$ ist ein essentieller Nährstoff für Pflanzenwachstum und -entwicklung, aber häufig ein limitierender Faktor in Waldökosystemen. Bis heute ist das Wissen über die Beziehungen zwischen wurzelassoziierten Pilzen mit ihren Umweltbedingungen und ihrer potentiellen Funktion bei der N-Ernährung der Bäume gering. Ziel dieser Dissertation war es, die Umweltbedingungen und Funktionen von wurzelassoziierten Pilzgemeinschaften im Zusammenhang mit $\mathrm{N}$ zu untersuchen.

Buchen (Fagus sylvatica) wurden als Wirtspflanzen ausgewählt, um die Beteiligung von Ektomykorrhizapilzen bei der N-Versorgung der Pflanzen zu untersuchen. Es wurde die Infrastruktur der Biodiversitäts-Exploratorien genutzt, welche 150 Waldplots (je $100 \times 100 \mathrm{~m}$ ) entlang drei biogeographischer Regionen mit einer Größe von 422 bis $1300 \mathrm{~km}^{2}$ (Schwäbische Alb, Hainich-Dün und Schorfheide-Chorin) umfasst, entlang eines 700 km langen Transektes durch Deutschland. Die Biodiversitäts-Exploratorien stellen eine gut organisierte Plattform für großräumige und langfristige Forschung zu funktioneller Biodiversität und den Auswirkungen von Landnutzung und geographischer Region zur Verfügung. In den drei Versuchsregionen wurde ein BuchenTransplantationsexperiment etabliert, bei dem junge Buchen, die aus verschiedenen Plots der drei Exploratorien stammten, in bestimmten Plots der Exploratorien nebeneinander angepflanzt wurden.

Die Ziele dieser Arbeit waren, (1) den Einfluß von ektomykorrhizaler Diversität und der Zusammensetzung ihrer Gemeinschaft auf die Ernährung mit anorganischem $\mathrm{N}$ und der Vitalität von Buchen verschiedener Herkunft zu beurteilen, (2) Erkenntnisse über die molekularen Mechanismen der Interaktionen zwischen Ektomykorrhizapilzen und Buchen zu bekommen, und (3) die wurzel-assoziierten Pilzgemeinschaften und ihre Beziehung zu Boden- und Wurzel-Stickstoff und -Kohlenstoff in temperaten Wäldern zu untersuchen. 
(1) Um den Einfluß der ektomykorrhizalen Pilzgemeinschaft und der Bodenbeschaffenheit auf die Ernährung mit anorganischem $\mathrm{N}$ und der Vitalität von Buchen zu untersuchen, wurden die Hypothesen aufgestellt, daß (i) die Leistungsfähigkeit und N-Ernährung von Buchen verschiedener Herkunft sich in derselben Umwelt unterscheiden, (ii) die Leistungsfähigkeit und N-Ernährung von Buchenherkünften sich aufgrund einer unterschiedlichen Zusammensetzung der Ektomykorrhizagemeinschaft unterscheidet, und (iii) die Buchenherkünfte der drei verschiedenen biogeographischen Gebiete die N-Form bevorzugen, die in ihrer ursprünglichen Umwelt vorherrscht. Um diese Hypothesen zu untersuchen, wurde ein Gewächshausexperiment durchgeführt, bei dem Buchen von drei verschiedenen Herkünften aus Bucheckern angezogen wurden. Die Diversität der Ektomykorrhizapilze wurde beeinflußt, indem die Buchensetzlinge in zwei verschiedene Bodenarten gepflanzt wurden: Beide Bodenarten stammten aus dem Gebiet Hainich-Dün. Einmal wurde der Boden so belassen, wie er dem Wald entnommen wurde; für den zweiten Ansatz wurde er zunächst sterilisiert und dann mit Bakterien reinokuliert. Nach zwei Jahren der Exposition wurden Biomasseentwicklung und Photosynthese als Vitalitätsindikatoren der Buchen gemessen, die Gemeinschaften der Ektomykorrhizapilze identifiziert und die N-Ernährung der Buchen durch die Nachverfolgung von zugeführtem, mit ${ }^{15} \mathrm{~N}$ markiertem $\mathrm{NH}_{4}{ }^{+}$und $\mathrm{NO}_{3}^{-}$untersucht. Die Effekte des Bodens und der Herkunft, sowie ihre Interaktion wurden mittels „allgemeiner linearer Modelle“ (general linear model) analysiert. Es wurden Ähnlichkeitsanalysen (analysis of similarity) der ektomykorrhizalen Gemeinschaften zwischen den verschiedenen Bodentypen und den unterschiedlichen Herkünften angewendet. Kanonische Korrespondenzanalysen (canonical correspondence analysis) wurden durchgeführt, um die Beziehungen zwischen pflanzlicher Biomasse, Stickstoff und ektomykorrhizalen Gemeinschaften zu erforschen. Entgegen der Erwartungen konnten keine genetisch bedingten Auswirkungen auf Wachstum, Stickstoffgehalt und ${ }^{15} \mathrm{~N}$-Aufnahme festgestellt werden. Eine Verbesserung der Leistungsfähigkeit und der Langzeit-N-Ernährung wurden an den Buchenherkünften festgestellt, die in unbehandelter Walderde kultiviert und von einer größeren ektomykorrhizalen Diversität kolonisiert waren, im Vergleich zu denen, die in sterilisierter Erde kultiviert wurden. Eine erhöhte Diversität von Ektomykorrhizapilzen hatte jedoch keinen Einfluß auf die ${ }^{15} \mathrm{~N}$-Aufnahme. Verschiedene Buchenherkünfte bevorzugten $\mathrm{NO}_{3}{ }^{-}$gegenüber $\mathrm{NH}_{4}{ }^{+}$.Insgesamt deuten die Ergebnisse darauf hin, daß die Leistungsfähigkeit von Buchen und deren N-Ernährung von Bodenmikroben 
kontrolliert werden, insbesondere von der Zusammensetzung der Ektomykorrhizagemeinschaft.

(2) Um Einblicke in die molekularen Mechanismen der Ektomykorrhizapilz-BuchenInteraktion zu erhalten, wurden die Transkriptome von Buchen und Pilzen charakterisiert und die Reaktionen von Pilz- und Buchen-Gentranskripten auf unterschiedliche Umweltbedingungen untersucht. Junge Buchen der Herkunft "Schorfheide-Chorin“ wurden in die drei biogeographisch unterschiedlichen Regionen der Biodiversitäts-Exploratorien gepflanzt. Nach zwei Jahren Wachstum unter Freilandbedingungen wurden die Buchenwurzeln geerntet und zur Untersuchung der Transkriptome verwendet. Nach einer Qualitätsfilterung wurden die bereinigten Sequenzen gegen Transkriptome von Buchen und Ektomykorrhizapilzen annotiert. Es wurden Transkripte mit signifikant verringerter oder erhöhter Häufigkeit in den drei Regionen nachgewiesen. Die Muster der Transkripthäufigkeit zwischen den drei Regionen wurden durch Hauptkomponentenanalyse (principal component analysis) sichtbar gemacht. Eine Gen-Ontologie-Analyse (gene ontology term analysis) wurde angewendet, um mögliche Funktionen von unterschiedlich exprimierten Genen zu erkennen. Das Transkriptom der Wurzeln aus Schorfheide-Chorin unterschied sich von denen in den anderen beiden Regionen. Die meisten unterschiedlich exprimierten und angereicherten Gen-Ontologie-Terme wurden zwischen Hainich-Dün und SchorfheideChorin nachgewiesen. Es wurden Buchengene (111) und Ektomykorrhizapilzgene (374) identifiziert, die mit der N-Aufnahme und -Assimilation in Verbindung gebracht wurden. Die nachgewiesenen Buchengene waren an der Nitrataufnahme und assimilation beteiligt, während die Pilzgene bei der Aufnahme und Assimilation von Ammonium beteiligt waren.

(3) Um die Diversität und Gemeinschaftszusammensetzung von wurzelassoziierten Pilzgemeinschaften und ihre Wechselbeziehungen mit der Stickstoff- und Kohlenstoffverfügbarkeit von Böden und Wurzeln in temperaten Wäldern zu erforschen, wurden die folgenden Hypothesen getestet: (i) die taxonomischen Gemeinschaftszusammensetzungen der wurzelassoziierten Pilze unterscheiden sich in verschiedenen biogeographischen Regionen, aber die trophischen Gemeinschaftszusammensetzungen sind ähnlich; (ii) wurzelassoziierte Pilzgemeinschaften werden aufgrund der engen Interaktionen der Ektomykorrhiza mit ihren Wirtspflanzen stärker durch die Wurzel- als die Bodenchemie gesteuert; und (iii) verschiedene ökologische Gruppen der wurzelassoziierten Pilze (symbiotroph, saprotroph und pathotroph) reagieren unterschiedlich auf umweltbedingte 
Veränderungen von Stickstoff und Kohlenstoff im Boden und in den Wurzeln. Um diese Hypothesen zu testen, wurden Feinwurzeln in 150 Waldplots der drei Exploratorien gesammelt und mit der Wurzel- und Bodenchemie korreliert. Dazu wurden die wurzelassoziierten Pilze durch Illumina-Sequenzierung (MiSeq) identifiziert. Die Zusammensetzung der wurzelassoziierten Pilzgemeinschaften wurde unter Verwendung von nichtmetrischer multidimensionaler Skalierung (non-metric multidimensional scaling) und Ähnlichkeitsanalysen (analysis of similarities) untersucht. Die Beziehungen zwischen der Häufigkeit von wurzelassoziierten Pilzen und abiotischen Variablen wurden mit linearen Mixed-Effekt-Modellen (linear mixed effects models) untersucht. Erwartungsgemäß unterschieden sich die Zusammensetzungen der taxonomischen Gemeinschaften in den drei Regionen signifikant, aber die Unterschiede der taxonomischen Gemeinschaftszusammensetzungen war größer, als die der trophischen, welche sich zwischen Schorfheide-Chorin und den anderen beiden Regionen nur geringfügig unterschied, zwischen der Schwäbischen Alb und HainichDün unterschieden sie sich nicht. Es wurde eine Korrelation zwischen den trophischen Pilzgruppen (symbiotroph, saprotroph und pathotroph) und $\mathrm{NH}_{4}{ }^{+}$und $\mathrm{NO}_{3}{ }^{-}$in den Wurzeln festgestellt, Stickstoff und Kohlenstoff in den Wurzeln hatten einen größeren Einfluß auf Veränderungen bei den Pilzgruppen, als diese Elemente im Boden. Die Abundanzen der in dieser Studie untersuchten Pilzbestände korrelierten mit dem $\mathrm{NO}_{3}{ }^{-}$ in den Wurzeln. Gemäß den Erwartungen wiesen verschiedene Pilzordnungen unterschiedliche Muster mit den abiotischen Variablen auf. Insgesamt stützen diese Ergebnisse die Annahme, daß funktionale Resilienz durch taxonomische Divergenz zwischen Schwäbischer Alb und Hainich-Dün erreicht werden kann. Biogeographische Region und $\mathrm{N}$ in den Wurzeln $\left(\mathrm{NH}_{4}{ }^{+}\right.$und $\left.\mathrm{NO}_{3}{ }^{-}\right)$waren vermutlich die treibende Kraft bei Veränderungen der Abundanz von wurzelassoziierten Pilzgemeinschaften in den Biodiversitäts-Exploratorien.

Zusammenfassend gibt diese Studie Einblicke in die Beziehungen zwischen wurzelassoziierten Pilzen und Stickstoff in temperaten Wäldern. Bei jungen Buchen wird die N-Ernährung durch die Ektomykorrhiza-Diversität kontrolliert. Wie das auf molekularer Ebene funktioniert, bleibt rätselhaft, da $\mathrm{NO}_{3}^{-}$, gestützt durch die BuchenGenexpression, die bevorzugte N-Quelle der Buchen war, während die Leistungsfähigkeit der Buchen auf molekularer Ebene durch die Mitwirkung von Pilzgenen erklärt werden könnte, die mit der Aufnahme und Assimilation von $\mathrm{NH}_{4}{ }^{+}$in Zusammenhang stehen. Biogeographische Region und $\mathrm{N}$-bezogene Variablen $\left(\mathrm{NH}_{4}{ }^{+}\right.$ und $\mathrm{NO}_{3}^{-}$) in Wurzeln waren die treibende Kraft für Veränderungen der 
Zusammensetzung wurzelassoziierter Pilzgemeinschaften in gemäßigten Wäldern. Die künftige Forschung sollte sich mit Taxon-spezifischer pilzlicher N-Aufnahme und der zeitlichen Dynamik wurzelassoziierter Pilzgemeinschaften befassen. Die Entwicklung eines Referenzgenoms für Fagus sylvatica wäre eine wichtige Grundlage für ein besseres Verständnis der molekularen Mechanismen von Buche-Pilz-Interaktionen. 
CHAPTER 1

\section{GENERAL INTRODUCTION}




\subsection{Temperate forest ecosystems}

Forest ecosystems have always been playing an important role in human existence and spiritual life: providing food, shelter and materials, maintaining the atmospheric balance and being a source of artistic inspiration (Gilliam 2016). Temperate forests are situated in regions where there is a mild climate, mainly found around the middle latitudes between the tropics and the Arctic and Antarctic polar regions (Fig. 1). In the Northern Hemisphere, temperate forests occur in eastern North America, northeastern Asia, and western and central Europe while in the Southern Hemisphere they are present in southern Chile, south-eastern Australia, Tasmania and parts of New Zealand (Gilliam 2016). Total area of temperate forests is about 10.4 million $\mathrm{km}^{2}$, accounting for six percent of all the Earth's ecosystems (Frelich et al. 2015). Distinct cyclic seasonal changes are among the noticeable features of temperate forest climate; however, temporal patterns of seasonal changes vary substantially depending on the different forest regions and latitudes (Gilliam 2016). Temperate forests at low latitudes, for example, have longer growing period than those at high latitudes (Gilliam 2016). Due to historic extensive use and conversion by human, temperate forest biodiversity has been extensively changed compared to the past (Franklin 1998). A number of natural temperate forests and their associated organisms have been overexploited or completely destroyed, and the remaining natural forest ecosystems are fragmented and highly altered (Franklin 1998). Therefore, most of the temperate forests nowadays are managed or secondary forests.

Forest ecosystems in Germany belong to Central Europe's temperate forest region. Key climatic features of the region are that summers are relatively warm without frost while winters are quite cold, with temperatures seldom being under $-20{ }^{\circ} \mathrm{C}$ in winter and over $30{ }^{\circ} \mathrm{C}$ in summer; the vegetation receives rainfall the year round (Leuschner and Ellenberg 2017). These climatic conditions are advantageous to the growth and development of deciduous broadleaved tree species which require relatively high precipitation of over $250 \mathrm{~mm}$ and mean temperatures in July over 15 ${ }^{\circ} \mathrm{C}$ (Frelich et al. 2015). The forested area of Germany is over 11.4 million hectares, accounting for around $32 \%$ of the total area of Germany. Despite an increasing demand on forest products, the 10-year period, from 2002 to 2012, witnessed an increase in the forested area, by 500,000 hectares (Friedrich et al. 2015). Over the past years, the federal governments in Germany have applied sustainable forest management practices (Häusler and Michael 2001). As a result, mixed forests have been established with a larger contribution of deciduous species such as beech and 
oak, and forests have been becoming more diversely structured (Friedrich et al. 2015). In fact, forest structure is diverse with $76 \%$ of mixed forests, and forests with two or multiple canopy layers accounting for $68 \%$ of the total forest area (Friedrich et al. 2015).

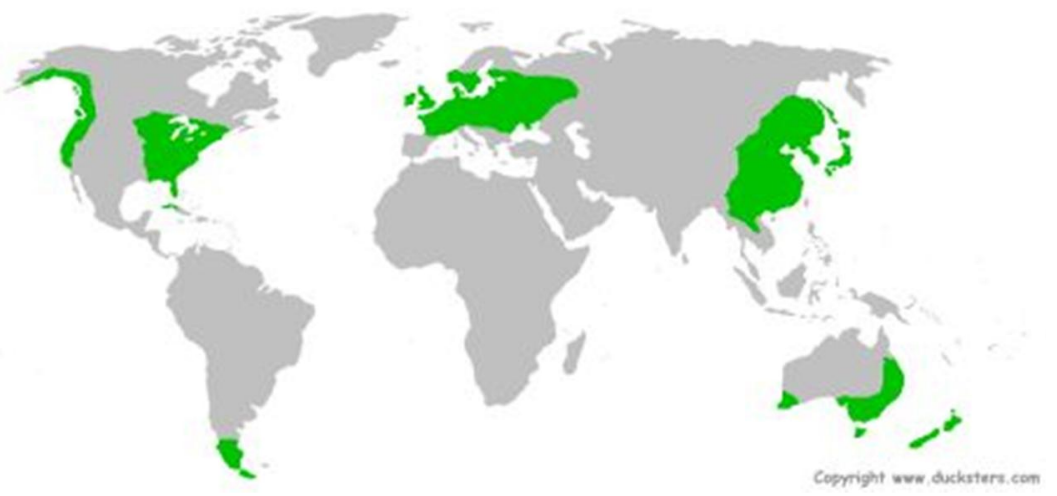

Fig. 1.1 Global distribution of temperate forests. Green colour indicates the temperate forests. Source: http://www.ducksters.com

European beech (Fagus sylvatica) forest area was 1,680,072 hectares in 2012, accounting for $21 \%$ of total forested areas in Germany (Friedrich et al. 2015). Beech is an economically and ecologically important tree species; it is the most abundant deciduous tree species in German forests. Beech occur throughout Germany, but mostly in the highlands of southern and central parts such as the SchwäbischeFränkische Alb, Plälzerwald, Eifel, Odenwald, Spessart and Solling (Friedrich et al. 2015). An increase of $12 \%$ or 151,000 hectares of the beech forest area was recorded between 1987 and 2002, followed by an increment of $6 \%$ or 102,000 hectares in 2012 (Friedrich et al. 2015). Beech is expected to be more popular in Germany in the coming years as a result of the sustainable forest management practices which aim to achieve increased mixed forest areas with deciduous species.

\subsection{Climate change and its effects on temperate forests}

An increase of up to around $1{ }^{\circ} \mathrm{C}$ in the Earth's surface temperature was recorded between 1850 and 2015; 2015 was the warmest year on record (EEA 2017). In the Northern Hemisphere, the 30-year period between 1983 and 2012 experienced the highest increase in surface temperature of the last 1400 years (IPCC 2014). By 2050 , the global temperature is estimated to surpass $2{ }^{\circ} \mathrm{C}$ compared to the preindustrial (between 1850 and 1900) level (EEA 2017). When the global surface temperature goes up, more frequent temperature extremes are to be expected in 
most regions (IPCC 2014). The long-term projection suggests for Germany an annual average temperature increase by 1.6 to $3.8^{\circ} \mathrm{C}$ until 2080 depending on the chosen climate scenarios (Schröter et al. 2005).

Increasing surface temperatures are also expected to result in changed precipitation patterns (Trenberth and Shea 2005). Globally, changes in precipitation will be not uniform among different parts of the Earth but depend on latitude and region (IPCC 2014). Change in average precipitation over land regions was low between 1901 and 1951, and medium afterwards (IPCC 2014). In the Northern Hemisphere, during the $20^{\text {th }}$ century precipitation went up by 0.5 to $1 \%$ per decade in the middle and high latitudes while it decreased in the subtropical latitudes (Zebisch et al. 2005). In the north-eastern and north-western Europe, an annual increase of $70 \mathrm{~mm}$ per decade has been recorded since 1960, while there was a decrease of up to $90 \mathrm{~mm}$ per decade in some parts of southern Europe (EEA 2017). Similarly, the projected precipitation is expected to change considerably across regions and seasons and will increase in northern Europe and decrease in southern Europe (EEA 2017). The frequency and severity of droughts tend to have gone up in Europe, in particular in southern Europe (EEA 2017). In Germany, a small change of less than $10 \%$ in annual precipitation is projected from 1990 to 2080, but with an increase in winter precipitation and a decrease in summer precipitation (Schröter et al. 2005).

A large scale meta-analysis of over 1700 species ranging from plants, birds, insects to fishes showed that climate change caused widespread changes in phenology and species distribution (Parmesan and Yohe 2003). Growing seasons of a number of plant species in the temperate areas has been changed due to climate change (Gilliam 2016). Habitats (14\%) and species (13\%) in Europe have already been considered as being under pressure due to climate change; these figures are projected to increase double in the near future (EEA 2017). Depending on the magnitude of global average temperature changes by the end of the $21^{\text {st }}$ century, forests in northern temperate regions are predicted to shift northward between 200 and $700 \mathrm{~km}$ (Frelich et al. 2015). Overall, it is clear that climate change will have profound effects on forests. However, many details especially with regard to the potential of temperate tree species to adapt to low precipitation are unclear.

\subsection{Nitrogen in temperate forests}

Many temperate forests are distributed on marginal soils with low $\mathrm{N}$ availability. $\mathrm{N}$ is essential for plant growth and development because it is an important component of genetic materials (DNA and RNA) and proteins (Ollivier et al. 2011). Under natural 
conditions, there is high abundance of $\mathrm{N}$ as atmospheric $\mathrm{N}_{2}$ as well as organic $\mathrm{N}$ compounds such as proteins or chitin in forests soils, but these $\mathrm{N}$ forms cannot be directly utilized by plants. To cope with low $\mathrm{N}$ nutrition, plants developed an association strategy with certain soil microorganisms such as $\mathrm{N}$-fixing bacteria and mycorrhizal fungi to turn inaccessible forms of $\mathrm{N}$ into simple and readily available $\mathrm{N}$ (Ollivier et al. 2011). However, atmospheric $\mathrm{N}$ deposition has been increasing all over the world due to anthropogenic impacts (Fig. 2). Increased $\mathrm{N}$ deposition was reported to influence negatively the ectomycorrhizal and plant communities in temperate forest ecosystems (Suz et al. 2014, de Witte et al. 2017). $\mathrm{NO}_{3}{ }^{-}$and $\mathrm{NH}_{4}{ }^{+}$ are the main forms that are be taken up by forest tree species. A preference of some tree species for one inorganic form of nitrogen over the other has been reported (McFee and Stone 1968, Schulz et al. 2011, Jacob and Leuschner 2014, Dannenmann et al. 2016). Most coniferous species have a preference for $\mathrm{NH}_{4}{ }^{+}$ whereas the preference of broadleaved tree species for the two $\mathrm{N}$ forms is less clear (Zhang and Bai 2003).
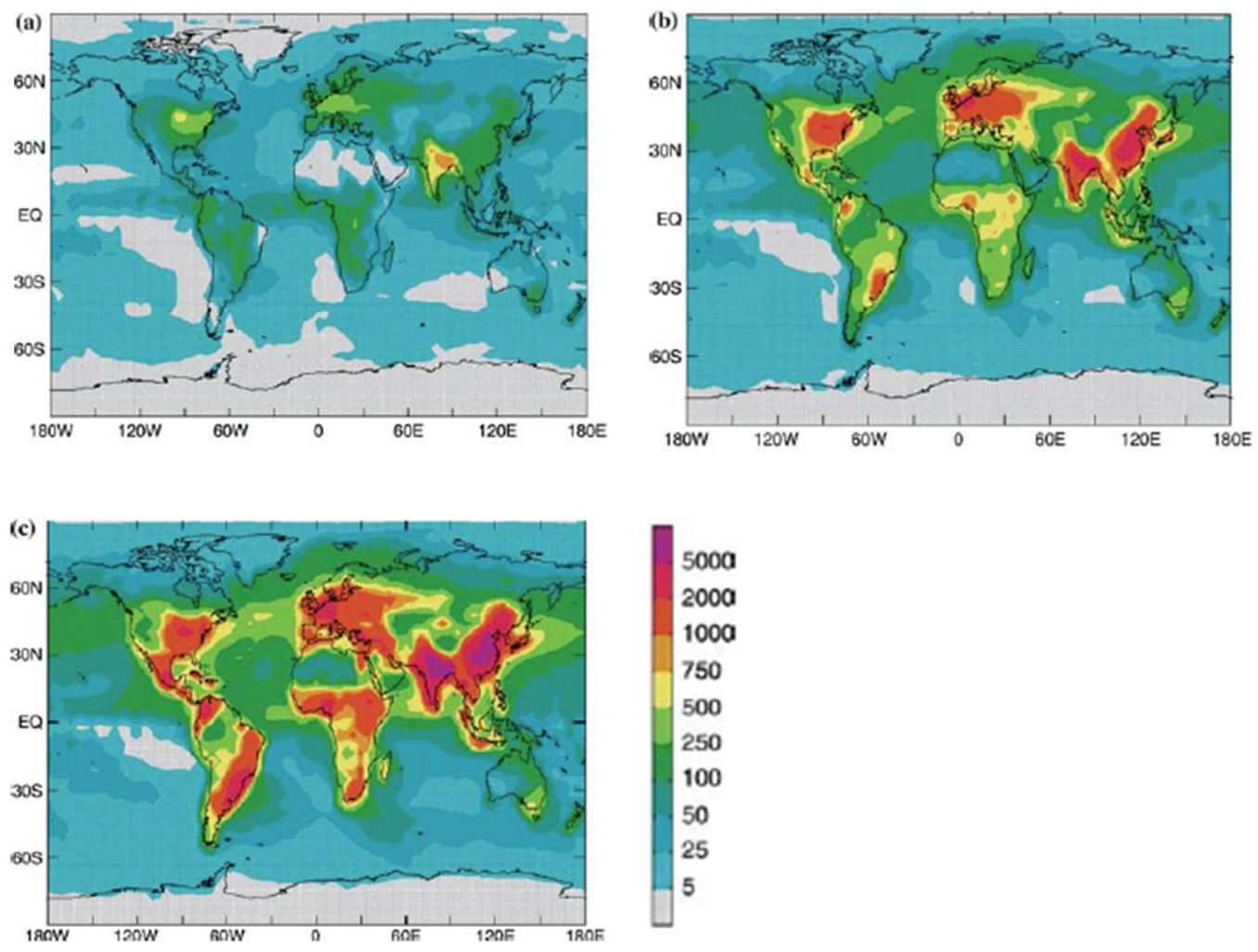

Fig. 1.2 Global spatial patterns of total inorganic nitrogen deposition in 1860 (a), 1990 (b) and 2050 (c). Unit scale is in $\mathrm{mg} \mathrm{N} \mathrm{m}^{-2}$ year $^{-1}$. Source: Galloway et al 2004 


\subsection{Root-associated fungi}

Ectomycorrhizal fungi (EMF) are of vital importance for tree nutrition in temperate forests, especially in areas with low nutrient availability (Smith and Read 2008) . EMF form a symbiotic association with a large number of tree species in temperate forests, and they benefit host trees by enhanced nutrient supply in exchange of photosynthetic carbon (Smith and Read 2008, Courty et al. 2010).

However, in their natural habitats, plants form association with not only with EMF, but with many different microbes, resulting in multi-species entities. In other words, a plant and its associated microbiota form a holobiont (Lundberg et al. 2012, Vandenkoornhuyse et al. 2015). Root-associated fungi (RAF) are important components of the plant microbiome (Porras-Alfaro and Bayman 2011). RAF are defined as any fungus residing within or on plant roots (Dean et al. 2014). RAF are highly diverse in taxonomy and perform multiple ecological functions (Dean et al. 2014, Peršoh 2015). Key trophic groups of RAF include symbiotrophs, saprotrophs and pathotrophs, endophytes and mycoparasites (Kernaghan 2013). Because simple, readily usable sugars are scarce in soil (Nehls et al. 2007), root exudates may be critical for root-associated fungal communities. Root saprotrophs, which live on plant roots, may further obtain carbon from dead root cells or dead ectomycorrhizal hyphae while pathogenic fungi achieve carbon from living root cells (Kernaghan 2013).

To date, we know little about the environmental drivers of RAF and their potential role for tree $\mathrm{N}$ nutrition. To investigate how the RAF communities are composed, analyses in temperate forest ecosystems are required. I conducted greenhouse and field studies to investigate EMF and RAF on forest tree roots. Here, the Biodiveristy Exploratories were the perfect platform for this research purpose.

The Biodiversity Exploratories (DFG Priority Programme 1374) are a research infrastructure which is funded by the German Research Foundation (www.biodiversity-exploratories.de). The Biodiversity Exploratories consist of 150 forest plots $(100 \mathrm{~m} \times 100 \mathrm{~m})$, which extend over various management types and landused intensity, in three different regions across Germany: Schwäbische Alb, Hainich-Dün and Schoefheide-Chorin. The project covers various aspects of research regarding the relationships among biodiversity, land-use changes and ecosystem processes through the application of a large number of monitoring, observational and experimental approaches. (Fischer et al. 2010). It provides thereby, a well-organized platform to conduct large-scale and long-term research on 
functional biodiversity under changing conditions of land use and geographical regions.

\subsection{Goals of this thesis}

The overarching aim of this study was to elucidate the diversity and function of rootassociated fungal communities in relation to nitrogen in temperate forests. The following aims were addressed:

(1) to assess the impact of ectomycorrhizal community composition on inorganic nitrogen nutrition and performance of beech provenances (Chapter 2). I set up a greenhouse experiment, in which I manipulated the diversity and composition of the EMF community of the host plants and studied $\mathrm{N}$ uptake of beech by ${ }^{15} \mathrm{~N}$ labeling;

(2) to obtain insights into molecular mechanisms of ectomycorrhizal fungibeech interaction (Chapter 3). Young beech plants from the provenance "Schorfheide-Chorin" were planted into Schwäbische Alb, Hainich-Dün and Schorfheide-Chorin and were used to study transcriptomes after two years of growth;

(3) to investigate the diversity and community composition of the rootassociated fungi and their relationships with soil and root nitrogen and carbon in three biogeographical regions (Chapter 4). Roots were sampled in 150 forest plots in the three biogeographical regions across Germany and used to identify fungal communities by Illumina sequencing. Soil and root nitrogen and carbon were determined.

\subsection{References}

Courty P-E, Buée M, Diedhiou AG, Frey-Klett P, Le Tacon F, Rineau F, Turpault MP, Uroz S, Garbaye J (2010) The role of ectomycorrhizal communities in forest ecosystem processes: New perspectives and emerging concepts. Soil Biol Biochem 42(5):679-698. doi:10.1016/j.soilbio.2009.12.006

Dannenmann M, Bimüller C, Gschwendtner S, Leberecht M, Tejedor J, Bilela S, Gasche R, Hanewinkel M, Baltensweiler A, Kögel-Knabner I, Polle A, Schloter M, Simon J, Rennenberg H (2016) Climate change impairs nitrogen cycling in european beech forests. PLoS One 11:e0158823. doi:10.1371/journal.pone.0158823

Dean S, Farrer E, Taylor DL, Porras-alfaro A (2014) Nitrogen deposition alters plant- 
fungal relationships: Linking belowground dynamics to aboveground vegetation change. Mol Ecol 23:1364-1378. doi: 10.1111/mec.12541

EEA (2017) Climate change, impacts and vulnerability in Europe 2016, EEA Report No 1/2017, European Environment Agency.

Fischer M, Bossdorf O, Gockel S, Hänsel F, Hemp A, Hessenmöller D, Korte G, Nieschulze J, Pfeiffer S, Prati D, Renner S, Schöning I, Schumacher U, Wells K, Buscot F, Kalko EKV, Linsenmair KE, Schulze E-D, Weisser WW (2010) Implementing large-scale and long-term functional biodiversity research: The

Biodiversity Exploratories. Basic Appl Ecol 11(6):473-485. doi:10.1016/j.baae.2010.07.009

Franklin JF (1998) Structural and temporal diveristy in temperate forests. In: Wilson, E.O. (Ed.), Biodiversity. National Academic Press, Washington DC, pp 166175.

Frelich LE, Montgomery RA, Oleksyn J (2015) Northern temperate forests. In: Northern Temperate Forest from: Routledge Handbook of Forest Ecology. doi: 10.4324/9781315818290.ch3

Friedrich S, Polley H, Hennig P, Kroiher F, Marks A, Riedel T, Schmidt U, Schwitzgebel F, Stauber T (2015) The Forests in Germany: Selected Results of the Third National Forest Inventory. Federal Ministry of Food and Agriculture.

Gilliam FS (2016) Forest ecosystems of temperate climatic regions: from ancient use to climate change. New Phytol 212:871-887. doi: 10.1111/nph.14255

Häusler A, Michael SL (2001) Sustainable Forest Management in Germany: The Ecosystem Approach of the Biodiversity Convention Reconsidered; Results of the R+D-project 80083001 , BfN-Skripten 51, German Federal Agency for Nature Conservation.

IPCC (2014) Climate Change 2014: Synthesis Report. Contribution of Working Groups I, II and III to the Fifth Assessment Report of the Intergovernmental Panel on Climate Change [Core Writing Team, R.K. Pachauri and L.A. Meyer (eds.)]. IPCC, Geneva, Switzerland, 151 pp.

Jacob A, Leuschner C (2014) Complementarity in the use of nitrogen forms in a temperate broad-leaved mixed forest. Plant Ecol Divers 8:243-258. doi:10.1080/17550874.2014.898166

Kernaghan G (2013) Functional diversity and resource partitioning in fungi associated with the fine feeder roots of forest trees. Symbiosis 61:113-123. 
doi: $10.1007 / \mathrm{s} 13199-013-0265-8$

Leuschner C, Ellenberg H (2017) Ecology of central Europe forests: Vegetation ecology of central Europe, Volumn I. Springer International Publishing.

Lundberg DS, Lebeis SL, Paredes SH, Yourstone S, Gehring J, Malfatti S, Tremblay J, Engelbrektson A, Kunin V, Rio TG del, Edgar RC, Eickhorst T, Ley RE, Hugenholtz P, Tringe SG, Dangl JL (2012) Defining the core Arabidopsis thaliana root microbiome. Nature 488:86-90.

McFee WW, Stone EL (1968) Ammonium and nitrate as nitrogen sources for Pinus radiata and Picea glauca. Soil Sci Soc Am J 32:879-884. doi:10.2136/sssaj1968.03615995003200060045x

Nehls U, Grunze N, Willmann M, Reich M, Kuester H (2007) Sugar for my honey: Carbohydrate partitioning in ectomycorrhizal symbiosis. Phytochemistry 68(1):82-91. doi:10.1016/j.phytochem.2006.09.024

Ollivier J, Töwe S, Bannert A, Hai B, Kastl EM, Meyer A, Su MX, Kleineidam K, Schloter M (2011) Nitrogen turnover in soil and global change. FEMS Microbiol Ecol 78:3-16. doi: 10.1111/j.1574-6941.2011.01165.x

Parmesan C, Yohe G (2003) A globally coherent fingerprint of climate change impacts across natural systems. Nature 421:37-42. doi: 10.1038/nature01286

Peršoh D (2015) Plant-associated fungal communities in the light of meta'omics. Fungal Divers 75:1-25. doi: 10.1007/s13225-015-0334-9

Porras-Alfaro A, Bayman P (2011) Hidden fungi, emergent properties: endophytes and microbiomes. Annu Rev Phytopathol 49:291-315. doi: 10.1146/annurevphyto-080508-081831

Schröter D, Zebisch M, Grothmann T (2005) Climate change in GermanyVulnerability and adaptation of climate-sensitive sectors. Klimastatusbericht des DWD 2005:44-56.

Schulz H, Härtling S, Stange CF (2011) Species-specific differences in nitrogen uptake and utilization by six European tree species. J Plant Nutr Soil Sci 174:28-37. doi:10.1002/jpln.201000004

Smith SE, Read DJ (2008) Mycorrhizal symbiosis, 3rd edn. Academic Press, London.

Suz LM, Barsoum N, Benham S, Dietrich H-P, Fetzer KD, Fischer R, García P, Gehrman J, Kristöfel F, Manninger M, Neagu S, Nicolas M, Oldenburger J, 
Raspe S, Sánchez G, Schröck HW, Schubert A, Verheyen K, Verstraeten A, Bidartondo MI (2014) Environmental drivers of ectomycorrhizal communities in Europe's temperate oak forests. Mol Ecol 23:5628-5644. http://doi.wiley.com/10.1111/mec.12947

Trenberth KE, Shea DJ (2005) Relationships between precipitation and surface temperature. Geophys Res Lett 32:1-4. doi: 10.1029/2005GL022760

Vandenkoornhuyse P, Quaiser A, Duhamel M, Le Van A, Dufresne A (2015) The importance of the microbiome of the plant holobiont. New Phytol 206:11961206. doi: $10.1111 / \mathrm{nph} .13312$

De Witte LC, Rosenstock NP, Van Der Linde S, Braun S (2017) Nitrogen deposition changes ectomycorrhizal communities in Swiss beech forests. Sci Total Environ 605-606:1083-1096. doi: 10.1016/j.scitotenv.2017.06.142

Zebisch M, Grothmann T, Schröter D, Haße C, Fritsch U, Cramer W (2005) Climate change in Germany. Vulnerability and adaptation of climate sensitive sectors. Potsdam Institute for Climate Impact Research.

Zhang Y, Bai S (2003) Effects of nitrogen forms on nutrient uptake and growth of trees. J Appl Ecol 14:2044-2048. 


\section{IMPACT OF ECTOMYCORRHIZAL COMMUNITY COMPOSITION AND SOIL TREATMENT ON INORGANIC NITROGEN NUTRITION AND PERFORMANCE OF BEECH} (FAGUS SYLVATICA L.) PROVENANCES

Published in Trees (2017) 31(6):1891-1904

Dung Quang Nguyen ${ }^{1,2}$, Rodica Pena ${ }^{1}$, Andrea Polle $^{1}$

1 Forest Botany and Tree Physiology, University of Goettingen, Büsgenweg 2, 37077, Göttingen, Germany

${ }^{2}$ Forest Protection Research Centre, Vietnamese Academy of Forest Sciences, Duc Thang ward, Bac Tu Liem district, Hanoi, Vietnam 
CHAPTER 3

BEECH AND FUNGAL TRANSCRIPTOMES IN RESPONSE TO DIFFERENT BIOGEOGRAPHICAL ENVIRONMENTS IN TEMPERATE FORESTS 


\subsection{Introduction}

Plants are not anymore known as individuals but as entities of multi-species, whereby their associated microorganisms are of importance for the growth and development of holobiont (Bordenstein and Theis 2015, Mitter et al. 2016). As a result, the fitness of plants is shaped by the hologenome which includes the genome of the plant as well as those of associated microbes (Mitter et al. 2016). Indeed, research on plant microbiome has considered microbes as a reservoir of extra genes for host plants (Vandenkoornhuyse et al. 2015). Plant microbiome are recruited mostly from the surrounding soil, and they can also be transmitted by seeds and the air (Sánchez-Cañizares et al. 2017).

Although microbes can reside on or within different parts of plants, root-associated microbial communities have received most of the attention for their interaction with the plant (Lareen et al. 2016). High microbial diversity on roots is driven by root exudates in the root environment, and thus the root is a hot spot of the interaction between plants and microorganisms which is especially crucial for plant nutrition and health (Mitter et al. 2016, Pérez-Jaramillo et al. 2016). Soil fungal communities were determined more strongly by geographical distance of habitats than those of the roots, and the root-associated fungal communities were recruited from soil fungal communities (Danielsen et al. 2012, Goldmann et al. 2016). The dominant groups of root-associated fungi were ectomycorrhizal fungi (EMF) (Danielsen et al. 2012, Goldmann et al. 2016), which are important for tree nutrition and stress tolerance (Luo et al. 2009, Danielsen and Polle 2014, Kaling et al. 2018).

Beech is a dominant deciduous tree species in Central Europe of economic and ecological importance (Leuschner and Ellenberg 2017). Beech forms ectomycorrhizas with a variety of soil fungi. Roots of European beech trees are extensively colonized by ectomycorrhizal fungi, accounting for $85 \%$ to almost $100 \%$ of root tips. In mature beech forests, the roots are colonized by up to 85-90 different EMF species (Pena et al. 2010, Lang and Polle 2011). Sixty-one EMF were found and characterized during year-round monitoring of ectomycorrhizal diversity and community composition in a mature beech forest (Buée et al. 2005).

Nitrogen can be translocated by EMF to their host plants through extraradical mycelium (Melin and Nilsson 1953, Finlay et al. 1989). Since $N$ is limited in many forest ecosystems, attention has been paid to the role of EMF in improving plant $\mathrm{N}$ supply (LeBauer and Treseder 2008). It was estimated that as much as $61-86 \%$ of $\mathrm{N}$ in arctic plants was supplied by mycorrhizal fungi (Hobbie and Hobbie 2006). $\mathrm{NH}_{4}{ }^{+}$ 
and $\mathrm{NO}_{3}{ }^{-}$are only forms of inorganic $\mathrm{N}$ which can be immediately accessed by plants, some plant species have a preference for one form over the other (Salsac et al. 1987, Forde and Clarkson 1999). Beech labeling study with ${ }^{15} \mathrm{NH}_{4}^{+}$showed that ${ }^{15} \mathrm{NH}_{4}^{+}$uptake by beech was correlated with ${ }^{15} \mathrm{NH}_{4}^{+}$enrichment in ectomycorrhizal tips (Pena and Polle 2014). When exposed to both $\mathrm{N}$ forms, mycorrhizal beech plants showed a preference for $\mathrm{NO}_{3}{ }^{+}$over $\mathrm{NH}_{4}{ }^{+}$(Dannenmann et al. 2016, Leberecht et al. 2016, Chapter 2). Tracer study with both $\mathrm{NH}_{4}{ }^{+}$and $\mathrm{NO}_{3}{ }^{-}$under field conditions showed that ${ }^{15} \mathrm{NH}_{4}{ }^{+}$uptake by EMF was higher than that of ${ }^{15} \mathrm{NO}_{3}^{-}$, but ${ }^{15} \mathrm{NH}_{4}^{+}$uptake by beech was lower than that of ${ }^{15} \mathrm{NO}_{3}{ }^{-}$(Leberecht et al. 2016).

However, our understanding of the role of EMF to beech $\mathrm{N}$ supply at a molecular level remains scarce. Molecular approaches based on RNA sequencing can be used to broaden our understanding about the mechanism and function of beechEMF interactions. The goals of the present study, therefore, were to characterize beech and fungal transcriptomes and to compare the functional contribution of fungal genes and those of beech genes to beech nitrogen nutrition. Young beech plants from the provenance "Schorfheide-Chorin" were planted in three biogeographical regions: Schwäbische Alb, Hainich-Dün and Schorfheide-Chorin. After two years of growth under field conditions, fine roots of beech seedlings were harvested and used to study transcriptomes.

\subsection{Materials and methods}

\subsubsection{Plant materials and experimental design}

A beech transplantation experiment (BTE) was established in three regions: Hainich-Dün $(H)$, Schorfheide-Chorin $(S)$ and Schwäbische Alb $(A)$ in the framework of the Biodiversity Exploratories by Kristina Schröter (Fig. 3.1, Appendix Table 3.1, Schröter 2015, Department of Forest Botany and Tree Physiology). Beech nuts of 12 provenances, four from each region, were collected in autumn 2011 (Appendix Table 3.1), treated and cultured under greenhouse conditions as characterized in the section of plant materials and growth conditions (Chapter 2). The only difference was that the substrate which was used for planting beech seedlings in this experiment was a sterilized mixture of soil and sand including four parts of soil (Fruhstorfer Erde Typ N, Hawite, Gruppe GmBH, Vechta, Germany), three parts of coarse sand (0.7-1.2 mm) and 1 part of fine sand (0.4-0.8 mm) (Melo Schwimmbadtechnik, Göttingen, Germany). In June 2012, the beech seedlings were acclimated to outdoor conditions under a shadowing net that removed $90 \%$ of incoming light. The seedlings were cultivated with Hakaphos Blau nutrient solution 
(Compo $\mathrm{GmbH}$, Münster, Germany) with only $40 \%$ of the amount recommended by the manufacturer until outplanting in forest plots.

In autumn 2012, beech seedlings were outplanted in the three regions. Key characteristics of the regions were presented in Table 2.1 (Chapter 2). The experiment was conducted in nine forest plots in each region (Appendix Table 3.1). In each plot, 120 beech seedlings were planted in two blocks (Fig. 3.1b). Sixty beech seedlings, five seedlings from each beech provenance, were planted in one block in a randomized design (Fig. 3.1b). The size of one block was $2 \mathrm{~m} \times 0.8 \mathrm{~m}$ with a distance of $20 \mathrm{~cm}$ between the beech seedlings (Fig. 3.1b). The distance between the two blocks was $60 \mathrm{~cm}$. An example of plot S35 was presented (Fig. 3.1c).

a)

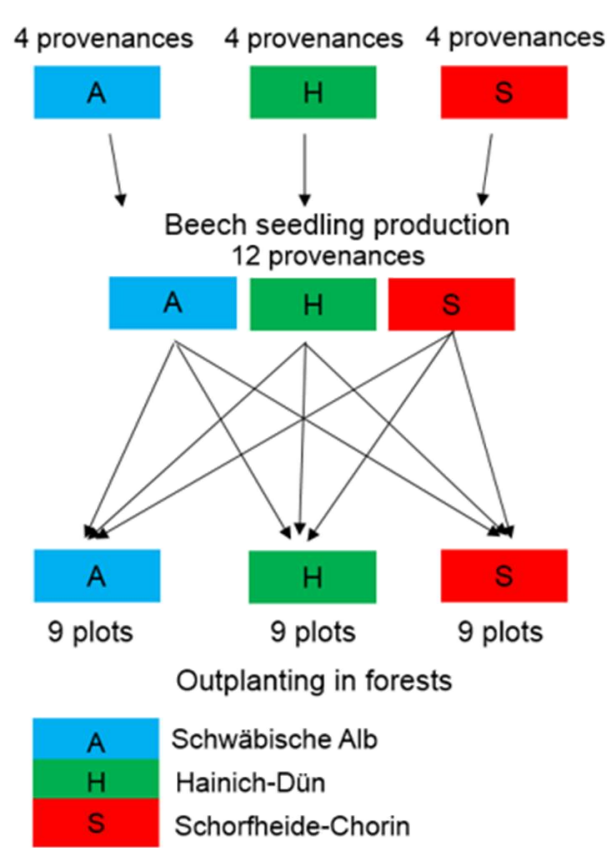

b)
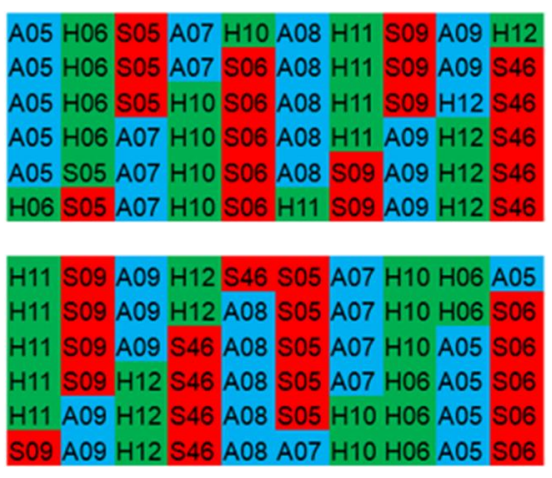

Experimental design

c)

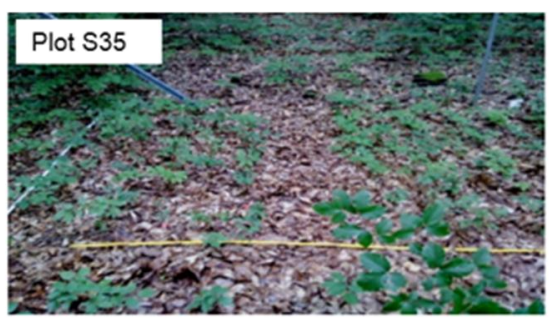

Photo: Silke Ammerschubert

Fig. 3.1 Beech Transplantation Experiment. Steps of setting up the experiment from the beech nut collection to seedling outplanting in forests (a), experimental design of one plot (b) and picture of plot 35 (c)

\subsubsection{Harvest}

From 25 August to 12 September 2014, whole seedlings were harvested in 14 forest plots in three regions (Appendix Table 3.1). On the harvest day, in each plot two beech seedlings from the same provenance were harvested with a split tube (12.5 $\mathrm{cm}$ diameter). The fine roots were separated from coarse roots, gently washed with cold water and immediately shock frozen in liquid nitrogen in the field. To obtain 
sufficient material for analyses, the root samples of two beech seedlings from the same provenance were pooled. Total collected root samples were 168 samples in three regions (48 samples from Hainich-Dün, 60 samples for each of the other two regions). The roots were transported in liquid nitrogen and stored at $-80{ }^{\circ} \mathrm{C}$.

\subsubsection{RNA extraction}

All 168 fine root samples were used for RNA extraction. Frozen fine roots were ground to a fine powder in liquid nitrogen with a ball mill (Type MM2, Retsch, Hann, Germany). Total RNA was extracted from the milled roots using a modified RNA extraction method (Chang et al. 2013). To an Eppendorf tube containing $150 \mathrm{mg}$ of the roots, $800 \mu$ l pre-warmed CTAB buffer and $16 \mu$ mercaptoethanol were added. One liter of the CTAB buffer contained: $2 \%$ hexadecyltrimethylammonium bromide $(\mathrm{pH}$ 8), 100mM trisaminomethane $\mathrm{HCl}, 25 \mathrm{mM}$ ethylenediaminetetraacetic acid, $2 \mathrm{M}$ $\mathrm{NaCl}$ and $2 \%$ polyvinylpyrrolidone $\mathrm{K} 30$. Subsequently, the Eppendorf tube was well mixed and incubated at $20000 \mathrm{~g}$ for $15 \mathrm{~min}$ at $65{ }^{\circ} \mathrm{C}$ on a thermo-mixer (Thermomixer Comfort, Eppendorf, Hamburg, Germany). The Eppendorf tube was then cooled down to $22{ }^{\circ} \mathrm{C}$ for $15 \mathrm{~min}$ with repeated shaking at $100 \mathrm{rpm}$. To the Eppendorf tube, a solution of $800 \mu \mathrm{l}$ of chloroform:isoamylalcohol (24:1) was added and incubated for $15 \mathrm{~min}$ at $22{ }^{\circ} \mathrm{C}$ for $1400 \mathrm{rpm}$ on a thermo-mixer and then centrifuged for $5 \mathrm{~min}$ at $22^{\circ} \mathrm{C}$ at $20000 \mathrm{~g}$ (5417R, Eppendorf, Hamburg, Germany). Then, the upper phase was transferred to a new $1.5 \mathrm{ml}$ Eppendorf tube, and the washing step for the upper phase was repeated for a second time. $200 \mathrm{ml}$ of $10 \mathrm{M}$ $\mathrm{LiCl}$ was added to the washed upper phase, mixed briefly and incubated for precipitation on ice at $4{ }^{\circ} \mathrm{C}$ overnight.

On the next day, the sample was centrifuged for 20 min at $4{ }^{\circ} \mathrm{C}$ at $20000 \mathrm{~g}$, and the supernatant was carefully discarded. $400 \mu \mathrm{l}$ SSTE buffer was added to the precipitate and incubated for $10 \mathrm{~min}$ at $42{ }^{\circ} \mathrm{C}$ on a shaker at $7400 \mathrm{~g}$ to dissolve the pellet completely. $100 \mathrm{ml}$ of the SSTE buffer ( $\mathrm{pH} 8)$ contained $0.5 \%$ sodium dodecyl sulfate, $10 \mathrm{mM}$ trisaminomethane $\mathrm{HCl}, 1 \mathrm{mM}$ ethylenediaminetetraacetic acid and 1 $\mathrm{M} \mathrm{NaCl}$. After $400 \mathrm{ml}$ of chloroform:isoamyl alcohol (24:1) was added to the sample tube, it was mixed briefly and centrifuged for $5 \mathrm{~min}$ at $22{ }^{\circ} \mathrm{C}$ at $20000 \mathrm{~g}(5417 \mathrm{R}$, Eppendorf, Hamburg, Germany). The upper phase was transferred into a $1.5 \mathrm{ml}$ Eppendorf tube, and the RNA was precipitated by adding $800 \mu \mathrm{l}$ of ethanol ( $96 \%$ (v:v), stored at $-20^{\circ} \mathrm{C}$, Carl Roth $\mathrm{GmbH}+$ Co. KG, Karlsruhe, Germany), incubating for $60 \mathrm{~min}$ at $-80{ }^{\circ} \mathrm{C}$ and centrifuging $20 \mathrm{~min}$ at $4{ }^{\circ} \mathrm{C}$ at $20000 \mathrm{~g}$. Five hundred $\mu \mathrm{l}$ of ethanol $(70 \%, v: v)$ was added to the sample tube and centrifuged for $10 \mathrm{~min}$ at 22 
${ }^{\circ} \mathrm{C}$ at $14000 \mathrm{rpm}$ to wash the pellet. The pellet was dried in a vacuum drier (Concentrator 5310, Eppendorf-Netheler-Hinz, Hamburg, Germany) at $45{ }^{\circ} \mathrm{C}$ for 3 min. The RNA was dissolved in $30 \mu \mathrm{l}$ of RNase-free water (AppliChem $\mathrm{GmbH}$, Darmstadt, Germany) and stored at $-80^{\circ} \mathrm{C}$.

RNA concentration and purity were evaluated in a NanodropTM 2000c spectrophotometer (Thermo Scientific, Waltham, MA, USA). The RNA absorbance ratio at $260 \mathrm{~nm}$ and $280 \mathrm{~nm}$ for the samples ranged from 1.94 to 2.15. A value for the $260 \mathrm{~nm} / 280 \mathrm{~nm}$ ratio of around 2 is usually considered as "pure" for RNA. RNA integrity was visualized by gel-electrophoresis. For this purpose, $0.6 \mathrm{~g}$ agarose was placed in a glass tube. Then, $35 \mathrm{ml}$ distilled water and $5 \mathrm{ml} 10 \mathrm{x}$ running buffer ( 1 liter of running buffer contained: $0.2 \mathrm{M} 3-(\mathrm{N}$-morpholino) propane sulfonic acid, $50 \mathrm{mM}$ sodium acetate and $10 \mathrm{mM}$ ethylenediaminetetraacetic acid $(\mathrm{pH} 8)$ were added to the tube and heated in $2 \mathrm{~min}$ in an 800-watt microwave oven to dissolve the mixture. In a fume hood, $10 \mathrm{ml}$ formaldehyde $(37 \%)$ was quickly added the tube. The mixture was used to make a gel using a plastic tray with a comb. After that the gel was placed on a gel running chamber containing $1 x$ running buffer. The mixture of $1 \mu \mathrm{l}$ RNA, $2 \mu \mathrm{l}$ nuclease free water and $2 \mu \mathrm{l} 2 \mathrm{x}$ loading buffer (for $1 \mathrm{ml}: 660 \mu \mathrm{l}$ formamid deionisiert, $140 \mu \mathrm{l}$ of nuclease free water, $100 \mu \mathrm{l}$ 10X running buffer, $80 \mu \mathrm{l}$ formaldehyde (37\%, v:v), $10 \mu \mathrm{l} 10 \%$ bromophenol blue and $10 \mu \mathrm{l}$ ethidium bromide) was loaded on the gel. The electrophoresis was run for $25 \mathrm{~min}$ at $100 \mathrm{~V}$, taken out and visualized at $300 \mathrm{~nm}$ excitation (Fluorescence-Multiimager, Bio-Rad, Munich, Germany). If an RNA sample was degraded (Sample ID 188, Fig. 3.2), the RNA extraction for that sample was repeated.

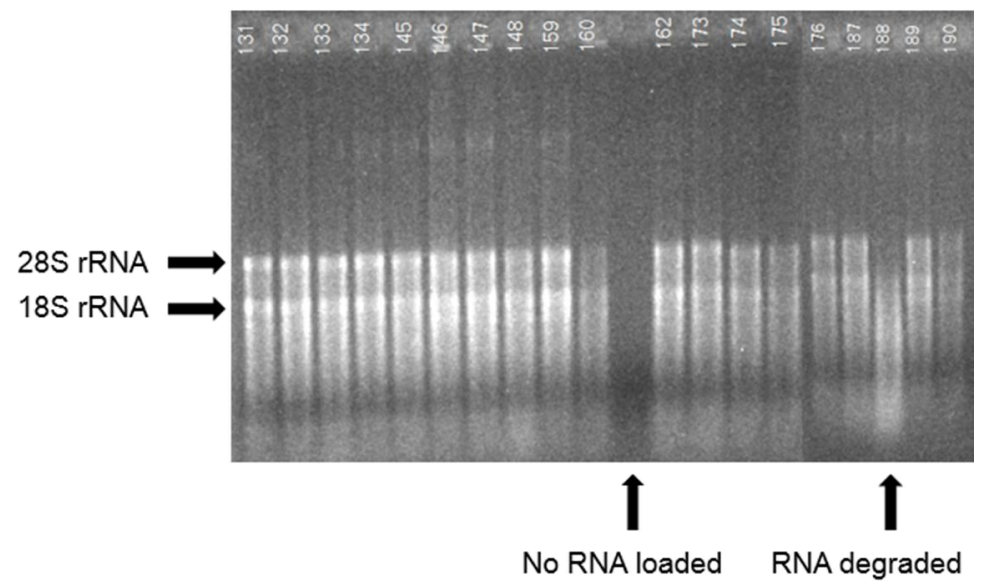

Fig. 3.2 Assessment of RNA intensity isolated from roots of beech seedlings by electrophoretic analysis. Numbers indicate the sample IDs. RNA bands were visualized using $1.2 \%$ agarose gel stained with ethidium bromide at the excitation wavelength of $300 \mathrm{~nm}$. 


\subsubsection{Library preparation and RNA sequencing}

In this study, seedlings from beech nuts of four Schorfheide-Chorin forest plots were selected for RNA sequencing (Appendix Table 3.1). Forty-eight RNA samples of the origin Schorfheide-Chorin, which came from four forest plots in each region, were used (Appendix Table 3.1). Four RNA samples of Schorfheide-Chorin origins from seedlings from the same plot were pooled with an equal concentration of $3 \mu \mathrm{g} / \mathrm{ml}$, thereby 12 RNA samples (one per plot) were obtained and used for RNA sequencing. The RNA samples were sent to Chronix Biomedical GmbH (Chronix Biomedical, Inc., Göttingen, Germany) for library preparation and sequencing. The RNA quality was once again determined using Agilent 2100 Bioanalyzer System (Agilent Technologies, Santa Clara, CA, USA. RNA). The RNA integrity numbers (RIN) of these samples ranged from 4.0 to 6.6 (Table 3.1). The cDNA libraries were prepared using NEBNext Ultra RNA Library Prep Kit for Illumina (New England BioLabs, Frankfurt am Main, Germany), and single-end reads were sequenced with a length of 150 bp in an Illumina HiSeq 2000 (Illumina, San Diego, CA, USA).

\subsubsection{Data analysis}

Raw sequence data were preprocessed with the FASTX-Toolkit (http://hannonlab.cshl.edu/fastx toolkit/). Sequences, which were smaller than $75 \mathrm{bp}$ or with a Phred score below 20, were discarded by using FASTQ Trimmer, and adapter sequences and primers, which were from NEBNext Ultra RNA Library Prep Kit for Illumina and used for RNA library preparation, were removed with FASTQ Clipper (http://hannonlab.cshl.edu/fastx toolkit/) to obtain cleaned reads. These sequences were mapped against transcriptomes of Fagus sylvatica deposited in a transcriptome shotgun assembly sequence database in GenBank (ID number HADB00000000.1) and against the transcriptomes of 27 fungal species (Appendix Table 3.2) downloaded from MycoCosm (Grigoriev et al. 2014) using Bowtie 2 (Langmead and Salzberg 2012). Bowtie mapping files were summarized to transcript count tables in R (R Core Team 2017).

To detect transcripts with significantly increased or decreased abundance under different conditions, the DEseq package (Love et al. 2014) was applied in R. Genes with an adjusted $p$ value $<0.05$ were considered differentially expressed. The $P$ values were adjusted to control the false discovery rate (Benjamini and Hochberg 1995). Principal component analysis (PCA) was used to visualize the pattern of transcript abundance among the three study regions. To obtain groups of genes according to functional role in the cell, Gene Ontology (GO) term enrichment was 
analyzed with Ontologizer (Bauer et al. 2008) using gene annotations of beech (Polle et al, unpublished) and the lists of differentially expressed genes between study regions as input data. The $\mathrm{P}$ values were adjusted using the Bonferroni method to determine enriched GO terms (Miller 1966). The Ontologizer produces a list of GO annotations, and these enriched GO terms were subsequently summarized in a hierarchy using GOPathDrawer (http://coxpresdb.jp/top draw.shtml).

To find out which fungal and beech genes were related to nitrogen, two approaches were used. The first was that all of the increased and decreased genes of beech and fungi among the three conditions were searched via nitrogen metabolism. In fact, the whole fungal transcriptome was sorted according to Enzyme commission (EC) number and mapped to KEGG pathway using KEGG mapper- Search \& Color Pathway (Kanehisa et al. 2017). To investigate beech genes which were involved in nitrogen metabolism, Paintomics 3 was used with Arabidopsis thaliana selected and total beech transcriptome as input data file, (version 0.4.5, http://bioinfo.cipf.es/paintomics/). The second approach was to search genes of nitrate transporters and ammonium transporters in the fungal and beech transcriptomes. To confirm the the contribution of beech and fungal genes from the samples to beech $\mathrm{N}$ uptake and assimilation, transcriptome of beech gene pool and that of Laccaria bicolor were also used to map to $\mathrm{N}$ metabolism, and comparison of $\mathrm{N}$-related genes between transcriptomes of the samples and gene pools were made.

\subsection{Results}

\subsubsection{RNA-Seq output and read mapping}

A total of 355.4 million reads from 12 samples with an average of about 29.6 million reads per sample were obtained by RNA sequencing (Table 3.1). The number of reads per sample ranged from 27.3 to 34.5 million reads (Table 3.1). After removing adapter and low-quality sequences, we obtained a total of above 211.8 million reads, with an average number of $17.7 \pm 0.35$ million reads per sample (Table 3.1). As a result, after quality filtering 60 percent of the reads remained for further analyses (Table 3.1). 
Table 3.1 Summary of numbers of reads after RNA sequencing of twelve samples from three biogeographical regions

\begin{tabular}{crrrrrr}
\hline Sample & Region & Plot & RIN ${ }^{\#}$ & $\begin{array}{r}\text { Numbers of } \\
\text { reads/sample }\end{array}$ & $\begin{array}{c}\text { Read } \\
\text { numbers after } \\
\text { quality filtering }\end{array}$ & $\begin{array}{c}\text { Reads after } \\
\text { quality } \\
\text { filtering (\%) }\end{array}$ \\
\hline 1 & H & H5 & 6.2 & 31043735 & 18919446 & 61 \\
2 & H & H12 & 5.3 & 30228997 & 18225988 & 60 \\
3 & H & H16 & 5.0 & 28030977 & 16316726 & 58 \\
4 & H & H21 & 5.4 & 29343454 & 16945089 & 58 \\
5 & S & S34 & 4.2 & 34521582 & 20816106 & 60 \\
6 & S & S35 & 6.3 & 29614473 & 16971806 & 57 \\
7 & S & S37 & 5.1 & 28391141 & 16773063 & 59 \\
8 & S & S38 & 4.3 & 28546089 & 17165667 & 60 \\
9 & A & A5 & 4.0 & 27313438 & 16281344 & 60 \\
10 & A & A6 & 5.3 & 28970637 & 17598466 & 61 \\
11 & A & A39 & 6.6 & 28563535 & 17220387 & 60 \\
12 & A & A42 & 5.1 & 30827671 & 18604504 & 60 \\
Mean & & & $5.2 \pm 0.2$ & 29616311 & 17653216 & 60 \\
Sum & & & & 355395729 & 211838592 & 60 \\
\hline
\end{tabular}

${ }^{\#}$ RNA integrity number

When reads from the 12 samples were mapped against transcriptome of Fagus sylvatica (131000 "genes", Table 3.2), 26.2 million hits were detected with an average of 2.2 million hits per sample (Table 3.2). Here, the beech "genes" were defined as follows: the assembled sequences obtained by de novo transcriptome assembly from a transcriptome shotgun assembly sequence database available in GenBank (ID number HADB00000000.1). The hits could subsequently be assigned to 51.4 thousand Fagus sylvatica gene IDs. On average, 43 hits per beech "gene" were found. For fungal data, 10.7 million hits were detected when the sequence reads of the 12 RNAseq samples were mapped against those of 27 EMF species, resulting in 895.2 thousand hits per sample (Table 3.2). The hits were annotated to fungal EC (enzyme commission) numbers, resulting in the assignment of a total of 169.7 thousand reads (Table 3.2). This corresponded to only four hits per fungal gene (Table 3.2). Because of the low coverage of hits per gene, the significance of a bulk differential expression analysis was questionable and therefore not attempted here. 
Table 3.2 Summary of results of mapping transcriptomic data of 12 samples against transcriptomes of Fagus sylvatica and 27 ectomycorrhizal fungi

\begin{tabular}{lcccccc}
\hline Kingdom & Gene pool & $\begin{array}{c}\text { Numbers } \\
\text { of hits }\end{array}$ & \multicolumn{2}{c}{ Mean number of hits per sample } & \multirow{2}{*}{$\begin{array}{c}\text { Mean numbers of } \\
\text { hits per gene }\end{array}$} \\
\cline { 4 - 5 } & & & mean & $\min$ & $\max$ & \\
\hline $\begin{array}{l}\text { Plant } \\
\text { (Fagus) }\end{array}$ & 131000 & 26168355 & 2180696 & 1890472 & 2649971 & 43 \\
Fungi & 190000 & 10742602 & 895217 & 541702 & 1325763 & 4 \\
\hline
\end{tabular}

\subsubsection{Analysis of transcript abundance}

An overall analysis of the whole transcriptomes by principal component analysis (PCA) ordination plots showed that the root samples from the $S$ regions were separated along PC1 from those of the $\mathrm{H}$ and $\mathrm{A}$ regions (Fig. 3.3). This pattern was consistent when the data of the transcript abundance of both beech and fungi (Fig. 3.3a) or beech transcript abundance data (Fig. 3.3b) or fungal transcript abundance data (Fig. 3.3c) were plotted. However, the differences appeared to be stronger between $\mathrm{H}$ and $\mathrm{S}$ than between $\mathrm{A}$ and $\mathrm{S}$.

When comparing the expression of beech root-related genes among the three biogeographical regions, 536 differentially expressed genes (DEGs) were identified between the $H$ and $S$ regions, 7 DEGs between the $H$ and $A$ regions, and 42 DEGs between the $S$ and $A$ regions (Fig. 3.4a). Three out of 7 genes, which were expressed differentially between $A$ and $H$ region, were also expressed differentially between $\mathrm{H}$ and $\mathrm{S}$ region (Fig. 3.4b). Twenty-three out of 42 of differentially expressed genes between $S$ and $A$ region, showed differential expression between $\mathrm{H}$ and $\mathrm{S}$ region (Fig. 3.4b). As a result, the difference in transcript abundances between $\mathrm{H}$ and $\mathrm{S}$ was higher than in the other combinations of the three regions. Twenty-three transcripts were common to $\mathrm{H}$ and $\mathrm{A}$ among the DEGs (Appendix Table 3.6). Among the common genes were transporters for iron, sulfate, phosphate and nitrate suggesting a difference in beech nutrient uptake between $S$ and the other two regions. 

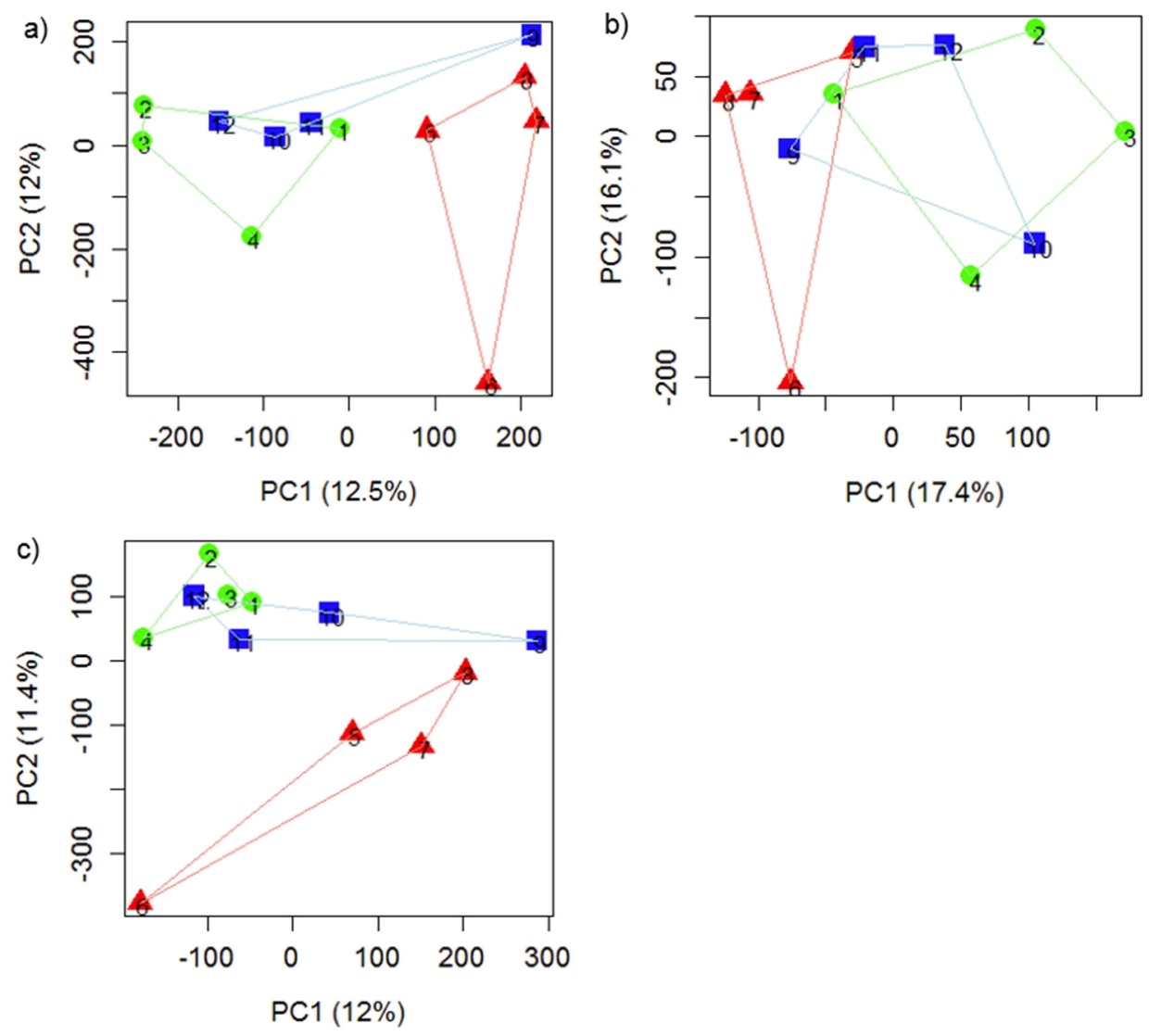

Fig. 3.3 Principal component analysis (PCA) for transcript abundance from three different biogeographical regions. Transcript abundance of both beech and fungi (a), beech transcript abundance (b) and fungal transcript abundance (c). Hainich-Dün (green circle), Schorfheide-Chorin (red triangle) and Schwäbische Alb (blue square). Sample numbers are shown according to Table 3.1.
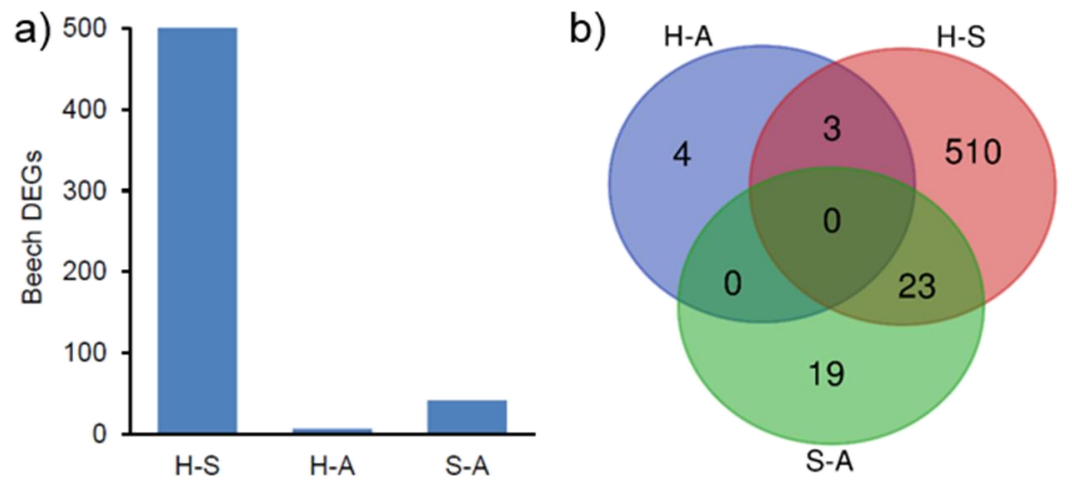

Fig. 3.4 Numbers of differently expressed genes (DEGs) of beech (a) and Venn diagrams for beech DEGs in pairwise comparison (b) among the three biogeographic regions 


\subsubsection{Analysis of Gene Ontology (GO) terms}

Beech DEGs were grouped according to different functional categories by $\mathrm{GO}$ term analysis. Based on the DEGs between $\mathrm{H}$ and $\mathrm{S}$, ninety-two $\mathrm{GO}$ terms were found to be enriched (Fig. 3.5). In this set, $87 \mathrm{GO}$ terms belonged to the category of "biological processes", and five GO terms were in the "molecular function" group.

In the category "biological processes", GO terms for biosynthesis and metabolism of olefin, alkene, ceramide, salicylic acid, phenol-and benzene-containing compounds, phosphorus, reactive oxygen species, toxin, camalexin, indole phytoalexin and monocarboxylic acid were detected (Fig. 3.5a). Furthermore, GO terms for the category "stimuli" were found: immune, acid, light intensity, chemicals, chitin, organic nitrogen, other organisms, boron deprivation (Fig. 3.5b). Other groups of GO terms with functions in the regulation of "stimuli" were present such as regulation of stress response, cell death, multi-organism process, immune system process, autophagy, cellular macromolecule biosynthesis, gene expression, RNA metabolic process, nitrogen and nucleobase-containing compound metabolic process, hydrogen peroxide, reactive oxygen species metabolic process (Fig. 3.5c). Among 87 GO terms in the category of "biological process", there were two N-related GO terms, GO:0010243 (response to organic nitrogen), GO: 0051171 (regulation of nitrogen compound metabolic process). There were 64 beech genes in GO:0010243 and 65 beech genes in GO:0051171 (Appendix Table 3.3).

The five GO terms in the category "molecular functions", were mainly related to nucleic acid binding. These GO terms were GO:0001067 (regulatory region nucleic acid binding), GO:0003677 (DNA binding), GO:0001071 (nucleic acid binding transcription factor activity), GO:0000975 (regulatory region DNA binding), and GO:0003700 (transcription factor activity, sequence-specific DNA binding).

There were only two enriched GO terms for beech DEGs between the $S$ and $A$ regions. These were GO:0019745 (pentacyclic triterpenoid biosynthesis process) and GO:0019742 (pentacyclic triterpenoid metabolic process). No enriched GO terms in the differential expression data between $\mathrm{H}$ and $\mathrm{A}$ plots was found. 

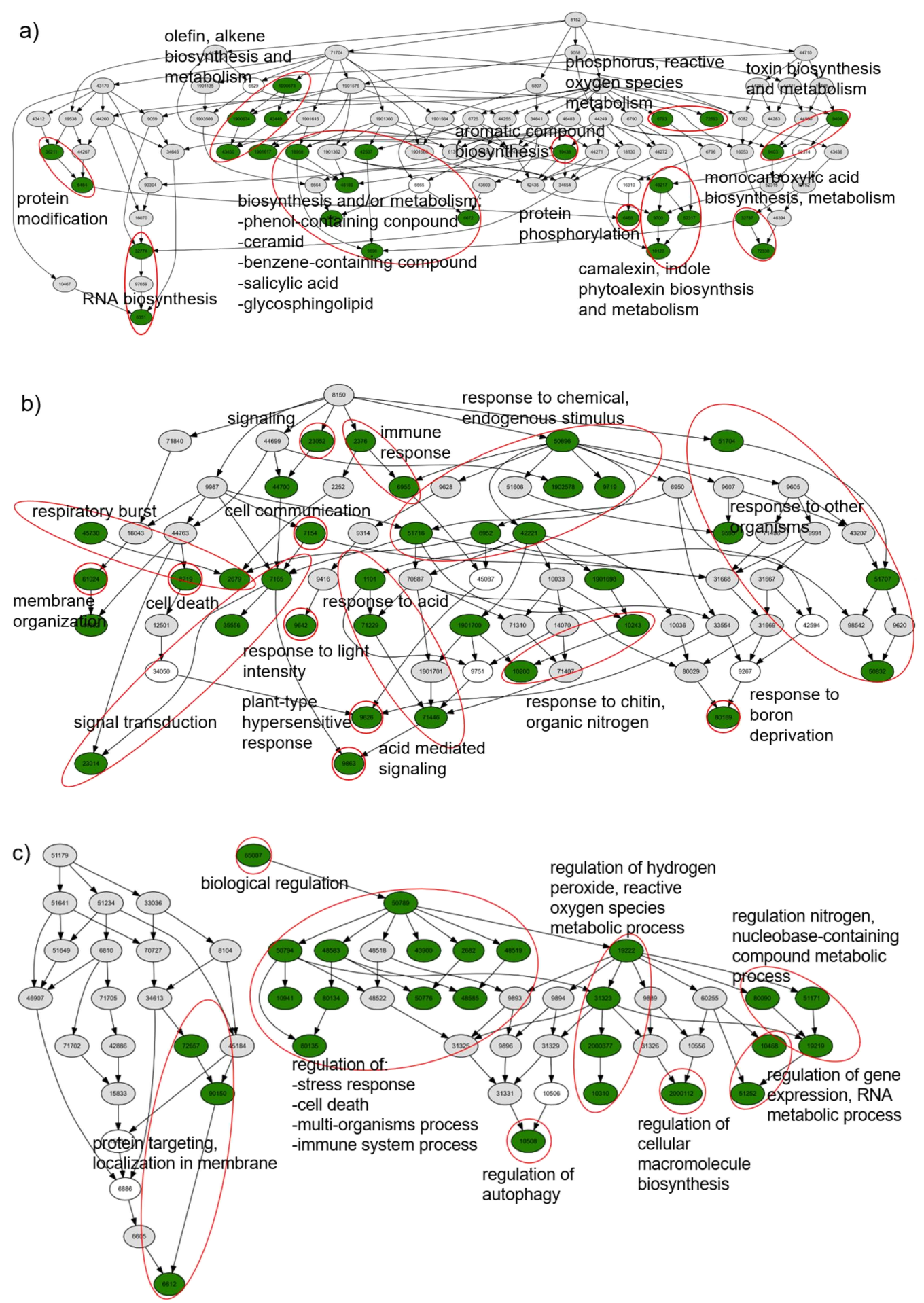

Fig. 3.5 Hierarchy of enriched GO terms of DEGs in relation to biological processes between $\mathrm{H}$ and $\mathrm{S}$ regions. Enriched $\mathrm{GO}$ terms are shown in green, others in white. The original figure (Appendix Fig. 3.1) was cut into three parts $(a, b, c)$. Some of the connections between the three parts were removed and can be found on the original figure (Appendix Figure 3.1). 


\subsubsection{Beech and fungal genes related to nitrogen uptake and assimilation}

Beech genes, which were related to $\mathrm{N}$ uptake and assimilation, were detected by mapping the beech transcriptome to $\mathrm{N}$ metabolism and keyword searching for nitrate and ammonium transporters in the beech transcriptome, resulting 111 hits (Table 3.3, Appendix Table 3.4). Among them, 80 beech "genes" were putatively involved in $\mathrm{N}$ metabolism (Fig. 3.6) and further in $\mathrm{N}$ transport such as nitrate transporters (5 NRT2.5 and 4 NRT2.7) (Table 3.3, Fig. 3.6). Three beech genes (nitrate reductase, $1 \mathrm{NIA} 1$ and $2 \mathrm{NIA} 2$ ) were likely involved in nitrate reduction, from nitrate $\left(\mathrm{NO}_{3}{ }^{-}\right)$to nitrite $\left(\mathrm{NO}_{2}{ }^{-}\right)$. Subsequently, $\mathrm{NO}_{2}^{-}$reduction to $\mathrm{NH}_{4}{ }^{+}$could be catalyzed by beech nitrite reductase, of which 4 NIR1 were detected (Table 3.3, Fig. 3.6). Beech genes of carbonic anhydrase (5 BCA5, 1 ACA1, 1 ACA4, 3 ACA7, 1 CA1 and 5 CA2) and acetamidase/formamidase family protein (3 AT4G37560) might further contribute to $\mathrm{NH}_{4}{ }^{+}$production (Table 3.3, Fig. 3.6). The rest of the beech genes were involved in L-glutamate biosynthesis in glutamate metabolism (Fig. 3.6). These genes included glutamine synthetase (2 GS2, 1 GLN1.3 and 7 GSR_1), glutamate synthase (9 GLT1, 6 GLU1, and 1 GLU2) (Fig. 3.6, Table 3.3).

In regard to $\mathrm{N}$-related fungal genes, 374 fungal genes were detected in the fungal transcriptome of the 27 EMF species, all of which were putatively involved in ammonium uptake and assimilation (Table 3.4). We found 102 fungal genes of ammonia permease in the fungal transcriptome (Table 3.4, Appendix Table 3.5) but no nitrate transporters. Among the detected N-related fungal genes 272 genes were found to be involved in $\mathrm{NH}_{4}^{+}$production and glutamate metabolism (Fig. 3.7, Table 3.4, Appendix Table 3.5). For instance, 25 genes (Nitrilase) from 14 EMF species were detected that may take part in the nitrite reduction to ammonia (Table 3.4, Fig. 3.7). Three fungal genes (carbamoyl-phosphate synthase (ammonia)) from three fungal species may take part in carbamoyl phosphate biosynthesis (Table 3.4, Fig. 3.7), and 91 fungal genes (carbonate dehydratase) from 27 EMF species were able to catalyze a reaction which produces carbonic acid from $\mathrm{CO}_{2}$ (Table 3.4, Fig. 3.7). The rest of the fungal genes (153 genes) can potentially participate in L-glutamate biosynthesis in glutamate metabolism from ammonia and L-glutamine (Table 3.4, Fig. 3.7).

When transcriptomes of the beech gene pool were used to map to $\mathrm{N}$ metabolism, the same result as mapped with the samples was obtained, indicating that due to the constraints of the data base further $\mathrm{N}$-related genes may not have been found (Appendix Fig. 3.2). To test the data base coverage, the transcriptome of Laccaria 
bicolor (Martin et al. 2008) was mapped against the $\mathrm{N}$ metabolism, revealing the absence of genes related to nitrite reduction to ammonia and carbamoyl phosphate biosynthesis. Most of the genes related to glutamate metabolism were present in $\mathrm{N}$ metabolism (Appendix Fig. 3.3).

Overall, while beech genes were involved in all the steps of nitrate uptake and assimilation (Fig. 3.6), fungal genes were related to ammonium uptake and assimilation in $\mathrm{N}$ metabolism (Fig. 3.7). 
Table 3.3 N-related genes in the beech transcriptome. These genes obtained from mapping the beech transcriptome against $\mathrm{N}$ metabolism and from doing keyword search for nitratre and ammonium transporters using the beech transcriptome

\begin{tabular}{|c|c|c|c|}
\hline Gene name & AGI ID & Putative function & Fasyl IDs \\
\hline ACA1 & AT3G52720 & alpha carbonic anhydrase 1 & 1621113 \\
\hline ACA4 & AT4G20990 & alpha carbonic anhydrase 4 & 2250854 \\
\hline ACA7 & AT1G08080 & alpha carbonic anhydrase 7 & $1776839,0593659,0569751$ \\
\hline AT1G51720 & AT1G51720 & $\begin{array}{l}\text { Amino acid dehydrogenase family } \\
\text { protein }\end{array}$ & $\begin{array}{l}2569622,2566762,1774376, \\
1271906,0129825,1015882\end{array}$ \\
\hline AT4G37560 & AT4G37560 & $\begin{array}{l}\text { Acetamidase/Formamidase family } \\
\text { protein }\end{array}$ & $2224379,1685580,0614143$ \\
\hline BCA5 & AT4G33580 & beta carbonic anhydrase 5 & $\begin{array}{l}\text { 1320821, 0239657, 2155958, } \\
2558280,0028039\end{array}$ \\
\hline CA1 & AT3G01500 & carbonic anhydrase 1 & 1394408 \\
\hline CA2 & AT5G14740 & carbonic anhydrase 2 & $\begin{array}{l}\text { 1886503, 2568912, 0144715, } \\
0138595,0119002\end{array}$ \\
\hline GDH1 & AT5G18170 & glutamate dehydrogenase 1 & $\begin{array}{l}2430631,2279097 \\
1182924,2559332 \\
2028990\end{array}$ \\
\hline $\mathrm{GDH} 2$ & AT5G07440 & glutamate dehydrogenase 2 & $\begin{array}{l}0450109,1384250,2567469, \\
2308625,0284218,2115554 \\
1488290,0976755\end{array}$ \\
\hline GLN1.3 & AT3G17820 & glutamine synthetase 1.3 & 0391853 \\
\hline GLT1 & AT5G53460 & $\begin{array}{l}\text { NADH-dependent glutamate } \\
\text { synthase } 1\end{array}$ & $\begin{array}{l}\text { 1319886, 2291512, } 0792729 \\
\text { 1680520, 1169052, } 0160678 \\
1058148,0076001,0076000\end{array}$ \\
\hline GLU1 & AT5G04140 & glutamate synthase 1 & $\begin{array}{l}1897902,2567974,2567363, \\
1169208,1622159,1460472\end{array}$ \\
\hline GLU2 & AT2G41220 & glutamate synthase 2 & 0603322 \\
\hline GS2 & AT5G35630 & glutamine synthetase 2 & 0700968,0170119 \\
\hline GSR_1 & AT5G37600 & glutamine synthase clone R1 & $\begin{array}{l}\text { 0952505, 2340284, 1832704, } \\
\text { 1163541, 1114376, } 0614595 \\
2546236\end{array}$ \\
\hline NIA1 & AT1G77760 & nitrate reductase 1 & 0609862 \\
\hline NIA2 & AT1G37130 & nitrate reductase 2 & 2169193,1594841 \\
\hline NIR1 & AT2G15620 & nitrite reductase 1 & $\begin{array}{l}\text { 0948436, 0829064, 0819600, } \\
0075946\end{array}$ \\
\hline NRT2.5 & AT1G12940 & nitrate transporter 2.5 & $\begin{array}{l}0845329,0321329,0688632, \\
0554271,2449251\end{array}$ \\
\hline NRT2.7 & AT5G14570 & high affinity nitrate transporter 2.7 & $\begin{array}{l}\text { 1283739, 2528693, 0036908, } \\
0027662\end{array}$ \\
\hline NRT1.1 & AT1G12110 & nitrate transporter 1.1 & 0092364,2558839 \\
\hline NRT1.5 & AT1G32450 & nitrate transporter 1.5 & $\begin{array}{l}\text { 0078523, 0117415, } 0760882, \\
\text { 1458839, 1463770, } 2418771 \\
2564957\end{array}$ \\
\hline NRT1.7 & AT1G69870 & nitrate transporter 1.7 & $\begin{array}{l}\text { 0224199, 2042055, 2273703, } \\
2568183\end{array}$ \\
\hline NRT1:2 & AT1G69850 & nitrate transporter $1: 2$ & $\begin{array}{l}0281961,0662237,1230789, \\
1235428,1316850,1342999 \\
2125755,2558101\end{array}$ \\
\hline AMT1;1 & AT4G13510 & ammonium transporter $1 ; 1$ & $\begin{array}{l}\text { 0129718, } 0375136,1065322, \\
1834562,2569115\end{array}$ \\
\hline AMT2 & AT2G38290 & ammonium transporter 2 & $\begin{array}{l}0341208,1489616,1594973, \\
1678058,2239635\end{array}$ \\
\hline
\end{tabular}

AGI: Arabidopsis Genome Initiative

Fasyl: Fagus sylvatica 
Table 3.4 N-related genes in the fungal transcriptome. These genes obtained from mapping the fungal transcriptome against $\mathrm{N}$ metabolism and from doing keyword search for nitratre and ammonium transporters using the fungal transcriptome

\begin{tabular}{|c|c|c|c|c|}
\hline KOG ID & EC number & Function & $\begin{array}{c}\text { Number of } \\
\text { fungal genes* }\end{array}$ & $\begin{array}{l}\text { Number of } \\
\text { fungal } \\
\text { species* }\end{array}$ \\
\hline $\begin{array}{l}\text { KOG1587, } \\
\text { KOG0382 }\end{array}$ & 4.2.1.1 & Carbonate dehydratase & 91 & 27 \\
\hline KOG0370 & 6.3.4.16 & $\begin{array}{l}\text { Carbamoyl-phosphate } \\
\text { synthase (ammonia) }\end{array}$ & 3 & 3 \\
\hline KOG2250 & 1.4.1.2 & Glutamate dehydrogenase & 33 & 26 \\
\hline KOG2250 & 1.4.1.4 & $\begin{array}{l}\text { Glutamate dehydrogenase } \\
(\mathrm{NADP}+)\end{array}$ & 15 & 14 \\
\hline KOG0399 & 1.4.1.13 & $\begin{array}{l}\text { Glutamate synthase } \\
\text { (NADPH) }\end{array}$ & 20 & 20 \\
\hline KO0683 & 6.3.1.2 & Glutamate-ammonia ligase & 85 & 25 \\
\hline $\begin{array}{l}\text { KOG0805, } \\
\text { KOG1231 }\end{array}$ & 3.5.5.1 & Nitrilase & 25 & 14 \\
\hline $\begin{array}{l}\text { KOG0682 } \\
\text { Sum }\end{array}$ & & Ammonia permease & $\begin{array}{l}102 \\
374\end{array}$ & 27 \\
\hline
\end{tabular}

EC: Enzyme Commission number

KOG: Eucaryotic Orthologous Groups of protein

* details of number of fungal genes and species in Appendix Table 3.2 


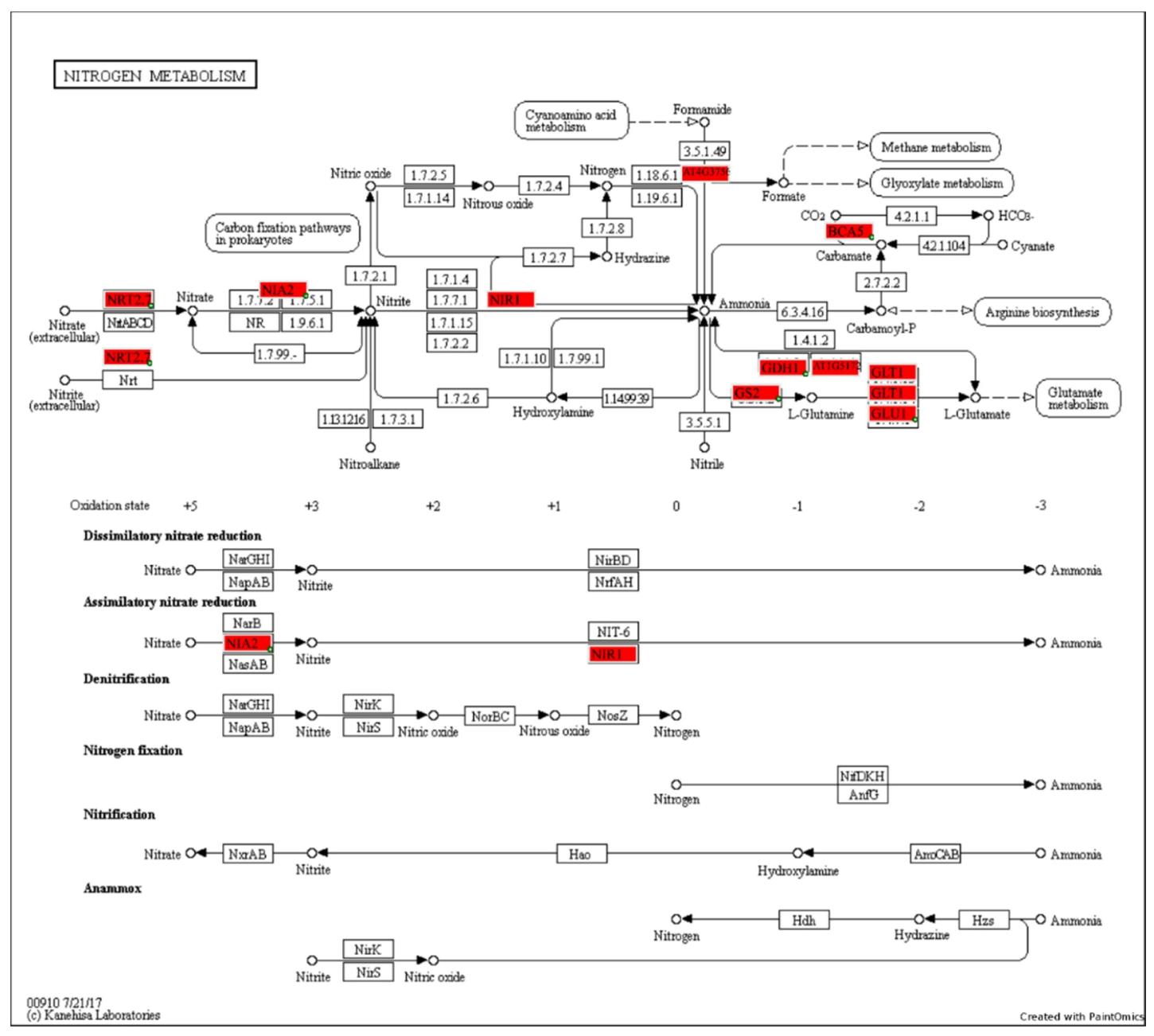

Fig. 3.6 Nitrogen metabolism of beech. Red colours indicate beech genes involved in nitrogen metabolism. The result was obtained from Paintomics 3 using list of genes from the beech transcriptome of the sample in this study according to AGI ID as input data. 


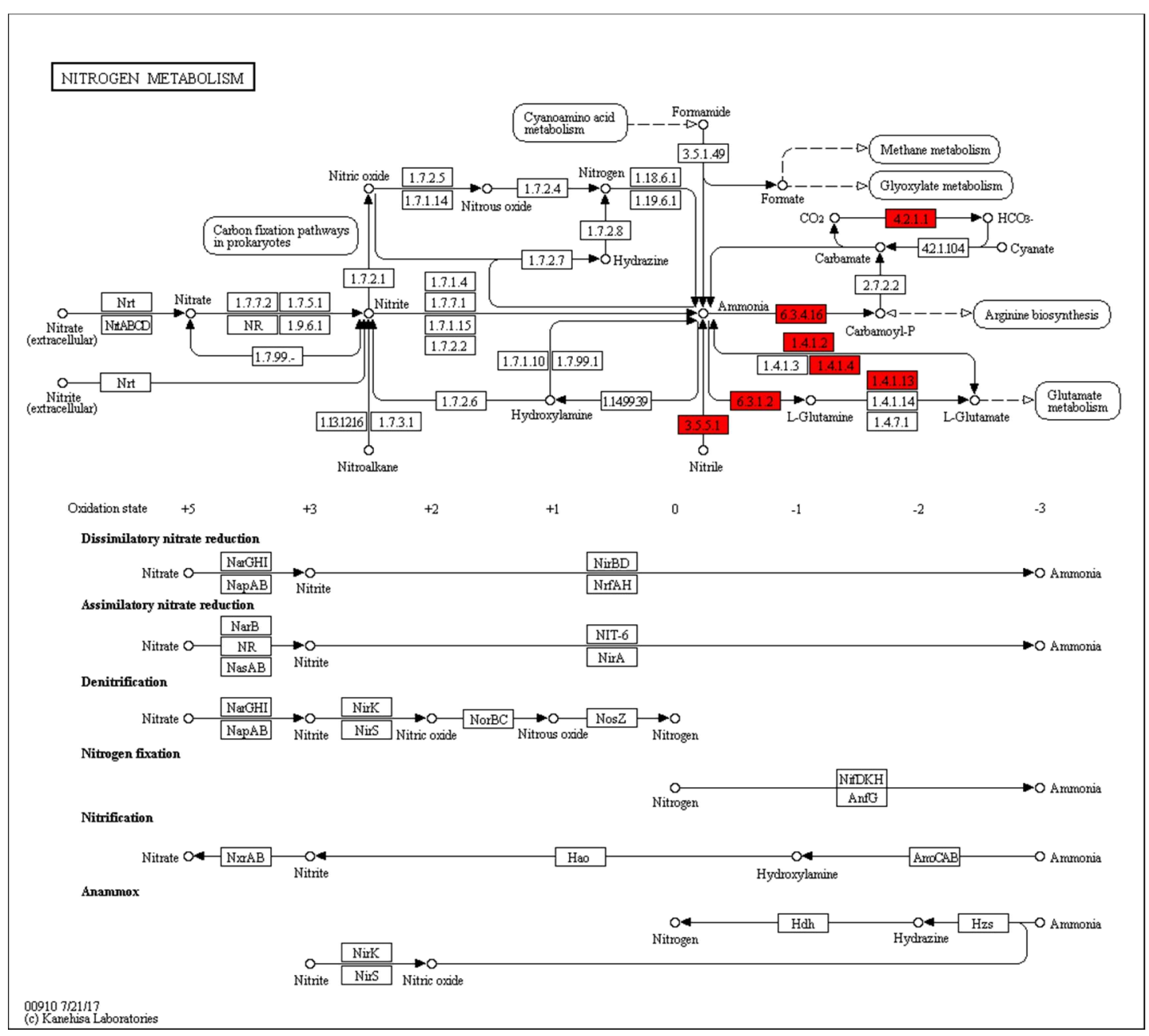

Fig. 3.7 Nitrogen metabolism of fungi. Red colour indicates fungal genes involved in nitrogen metabolism. The result was obtained from KEGG mapper-Search\&Color Pathway using EC number from the fungal transcriptome as input data

\subsection{Discussion}

\subsubsection{Limitations of RNA-Seq of beech roots}

The objectives of the present study were to characterize beech and fungal transcriptomes in three biogeographical environments and investigate the role of EMF in beech $\mathrm{N}$ supply at a molecular level. Since the beech genome has not been sequenced, mapping with the whole genome of beech is not possible (Müller et al. 2017). Therefore, the transcriptomes from the samples in this study were mapped against a beech transcriptome generated in a previous project on the basis of different tissues (leaves, wood and roots). Annotations of beech genes can be based on those of tree species which are genetically close to beech such as oak (Fagaceae). However, although the oak genome has been sequenced (Plomion et al. 2016) most genes of the oak genome have been not annotated yet. The best 
annotated tree species is poplar (Tuskan et al. 2004) whose gene annotations have, however, been mainly based on those of Arabidopsis thaliana. Therefore, in this study Fasyl IDs were assigned by their sequence similarities to genes of the model plant Arabidopsis thaliana.

Transcriptomes of twenty-seven EMF species downloaded from MycoCosm were used in this study (Grigoriev et al. 2014, Appendix Table 3.2). These species were selected because they are associated with beech and commonly found in the temperate forests in the three study regions (Schröter 2015). One limitation in this study is that because many EMF species were used for mapping the transcriptomes, on average only four hits per fungal genes were discovered (Table 3.2). This made further analysis such as differential expression analysis and GO term analysis of differentially expressed fungal transcriptomes unreliable, therefore, these analyses were not conducted for fungal transcriptomes in this study. To overcome those drawbacks, I suggest to use root tips, instead of fine roots, for RNA extraction and sequencing to achieve a higher abundance of fungal transcripts than in the present study. Secondly, information about abundance of EMF species on the root tips used for RNA-Seq should be obtained, and only the genomes of the most abundant EMF could then be used for mapping. Thirdly, the depth of RNA sequencing should be enhanced, then more fungal transcripts would be detected. Thereby the coverage of hits per gene for fungi can be enhanced.

\subsubsection{Differentially expressed genes of beech in three biogeographical regions}

Principal component analysis (PCA) showed that patterns of transcript abundances were different between $S$ and the other two regions when beech and fungal transcriptomes, beech transcriptomes or fungal transcriptomes were plotted (Fig 3.3a,b,c), and higher numbers of DEGs were observed between $S$ and the two other regions than between $A$ and $H$ region (Fig. 3.4a). The difference may be related to different environmental conditions in the $S$ region compared with the $A$ and $H$ regions (Table 2.1, Chapter 2). Indeed, in $S$ region has higher temperature, lower precipitation and more sandy soil than the other two regions (Table 2.1, Chapter 2).

Transcriptome studies of beech roots have not been conducted before. Recent studies on drought stress-related transcriptomes and individual genes from beech leaf samples showed different gene expression between drought stress and control treatments and between regions with different levels of water availability (Carsjens et al. 2014, Müller et al. 2017). Different expression levels of beech genes were also detected between two different phenological stages and between different time 
points of ozone exposure, but elevated ozone showed small effects on the gene expression level of beech plants (Olbrich et al. 2009, 2010, Lesur et al. 2015). Here, I speculated that a clearer pattern of PCA plots with $S$ region more separated from $A$ and $H$ regions would be observed and higher number of DEGs between $S$ and $A$ regions will be detected when the number of biological samples used for sequencing was enhanced. Future research should address the question to what extent different EMF colonizing the roots are contributing to the observed differences.

Here, I found that 23 beech DEGs were in common between $A$ and $\mathrm{H}$ (Fig 3.4b). These genes may be related to higher environmental stress in the $S$ region compared to the other regions (Fig. 3.4b). Therefore, functions of these genes were checked (Appendix Table 3.6). It was found that 4 beech genes were related to plant defense response to pathogens. These genes ID included 1232754 and 1905152 (pathogenesis-related family protein), 2556709 (disease resistance protein (CCNBS-LRR class) family and 0654506 (Late embryogenesis abundant (LEA) hydroxyproline-rich glycoprotein family) (Appendix Table 3.6). Moreover, among the 23 genes, five beech genes associated with nutrition transport were detected 2568183 (nitrate transporter 1.7), 1051267 (phosphate transporter 1;4), 2568106 (phosphate transporter 1.7), 1656484 (vacuolar iron transporter 1) and 0020415 (sulfate transporter 91). A lower concentration of $\mathrm{NO}_{3}{ }^{-}$in the soil $\mathrm{S}$ than in the other two regions might have caused the enhanced expression of nitrate transporter (Table 2.1, Chapter 2). As a result, the DEGs might be related to the difference in the root pathogen and nutrition status between $S$ and the other two regions which need to be further investigated because it was found that dead root tips in $S$ region were significantly more frequent than in the $\mathrm{H}$ and $\mathrm{A}$ regions (Chapter 4).

\subsubsection{N-related genes of beech and fungi}

The analysis of functions of beech DEGs revealed 64 genes belonging to GO:0010243 (response to organic nitrogen) and 65 genes belonging to GO:0051171 (regulation of nitrogen compound metabolic process) (Appendix Table 3.3). In a recent transcriptome study of young beeches in response to drought stress, two enriched GO terms related to $\mathrm{N}$ including GO:0050463 (nitrate reductase $[\mathrm{NAD}(\mathrm{P}) \mathrm{H}]$ activity) and GO:0050464 (nitrate reductase (NADPH) activity) were also detected (Müller et al. 2017). Based on the results from GO term analysis, it is of interest to know whether the $\mathrm{N}$-related genes were involved in $\mathrm{N}$ metabolism.

Here, I uncovered that beech genes involved in nitrate uptake and fungal genes involved in ammonium uptake and turn over were enhanced in $\mathrm{H}$ compared to $\mathrm{S}$. 
These results suggesting differences between fungal and plant genes for $\mathrm{N}$ usage are in agreement with a number of studies. In a field labeling experiment with both $\mathrm{NH}_{4}{ }^{+}$and $\mathrm{NO}_{3}{ }^{-}$, EMF took up more ${ }^{15} \mathrm{NH}_{4}{ }^{+}$than ${ }^{15} \mathrm{NO}_{3}^{-}$regardless of water supply, season, and site exposure, while young beech trees preferred ${ }^{15} \mathrm{NO}_{3}{ }^{-}$over ${ }^{15} \mathrm{NH}_{4}{ }^{+}$ (Leberecht et al. 2016). In another study in which metatranscriptomic analysis were compared between ectomycorrhizal roots of Piloderma-Pinus symbiosis and soil, it was also found that a gene encoding $\mathrm{NH}_{4}{ }^{+}$transporter (PiAMT) was highly expressed (Liao et al. 2014); furthermore, a high level of expression of genes encoding glutamine synthase and glutamate-related transporters were detected in fungal hyphae and ectomycorrhizal roots pointing to glutamate metabolism. It was concluded that the glutamine pathway is the key for $\mathrm{NH}_{4}{ }^{+}$assimilation and $\mathrm{N}$ use in Piloderma (Liao et al. 2014). Also, our results were in line with a study on oak root in response to ectomycorrhizal symbiosis (Sebastiana et al. 2014). When comparing ectomycorrhizal roots and non-mycorrhizal roots, 2238 differentially expressed transcripts were detected. Among them, a high level of expression for a transcript encoding a putative carbonic anhydrase (CA, EC 4.2.1.1) was detected. This enzyme is capable of converting $\mathrm{CO}_{2}$ to bicarbonate $\mathrm{HCO}_{3}^{-}$. For $\mathrm{N}$ transport, $\mathrm{NH}_{4}{ }^{+}$ and amino acid transporters were detected to be differently expressed (Sebastiana et al. 2014). Nitrogen assimilation-related genes such as glutamine synthetase, nitrite reductase, nitrite transporter were also differentially expressed when forming the symbiosis (Sebastiana et al. 2014). Furthermore, research on diversity of expressed genes in spruce and beech forest soil by metatranscriptomics showed that $12-13 \%$ of the transcripts, which encode proteins with enzymatic activities, could be assigned to an EC (Enzymatic Commission) number (Damon et al. 2012). Key enzymes in pathways related to soil nutrient assimilation were glutamine synthase (EC 6.3.1.2), NADPH-glutamate dehydrogenase (EC 1.4.1.4), glutamate synthase (EC 1.4.1.13) for ammonium, adenylyl transferase (EC 2.7.7.4), aldehyde reductase (EC 1.1.1.21) (Damon et al. 2012). Regarding inorganic nutrient transport, ammonium transporter (T.C.1.A.11.), phosphate transporters, but no nitrate (T.C.2.A.1.8) and sulfate (T.C.2.A.53.1) transporters were detected (Damon et al. 2012). These results are in agreement with those of this study. Overall, the results suggest the possible contribution by EMF to beech $\mathrm{NH}_{4}{ }^{+}$supply and assimilation.

\subsection{References}

Bauer S, Grossmann S, Vingron M, Robinson PN (2008) Ontologizer 2.0-a multifunctional tool for GO term enrichment analysis and data exploration. Bioinformatics 24:1650-1651. doi: 10.1093/bioinformatics/btn250 
Benjamini Y, Hochberg Y (1995) Controlling the false discovery rate: A practical and powerful approach to multiple testing. J R Stat Soc Ser B 57:289-300. doi:10.2307/2346101

Bordenstein SR, Theis KR (2015) Host biology in light of the microbiome: Ten principles of holobionts and hologenomes. Plos Biol 13:e100222. doi: 10.1371/journal.pbio. 1002226

Buée M, Vairelles D, Garbaye J (2005) Year-round monitoring of diversity and potential metabolic activity of the ectomycorrhizal community in a beech (Fagus silvatica) forest subjected to two thinning regimes. Mycorrhiza 15:235-245. doi:10.1007/s00572-004-0313-6

Carsjens C, Ngoc QN, Guzy J, Knutzen F, Meier IC, Müller M, Finkeldey R, Leuschner C, Polle A (2014) Intra-specific variations in expression of stressrelated genes in beech progenies are stronger than drought-induced responses. Tree Physiol 34:1348-1361. doi: 10.1093/treephys/tpu093

Chang S, Puryear J, Cairney J (1993) A simple and efficient method for isolating RNA from pine trees. Plant Mol Biol Report 11:113-116. doi: $10.1007 / \mathrm{bf0} 2670468$

Damon C, Lehembre F, Oger-Desfeux C, Luis P, Ranger J, Fraissinet-Tachet L, Marmeisse R (2012) Metatranscriptomics reveals the diversity of genes expressed by eukaryotes in forest soils. PLoS One 7: e28967. doi: 10.1371/journal.pone.0028967

Danielsen L, Polle A (2014) Poplar nutrition under drought as affected by ectomycorrhizal colonization. Environ Exp Bot 108:89-98. doi: 10.1016/j.envexpbot.2014.01.006

Danielsen L, Thürmer A, Meinicke P, Buée M, Morin E, Martin F, Pilate G, Daniel R, Polle A, Reich M (2012) Fungal soil communities in a young transgenic poplar plantation form a rich reservoir for fungal root communities. Ecol Evol 2:19351948. http://doi.wiley.com/10.1002/ece3.305

Dannenmann M, Bimüller C, Gschwendtner S, Leberecht M, Tejedor J, Bilela S, Gasche R, Hanewinkel M, Baltensweiler A, Kögel-Knabner I, Polle A, Schloter M, Simon J, Rennenberg H (2016) Climate change impairs nitrogen cycling in european beech forests. PLoS One 11:e0158823. doi:10.1371/journal.pone.0158823

Finlay RD, Ek H, Odham EK, Söderstöm B (1989) Mycelial uptake, translocation 
and assimilation of $15 \mathrm{~N}$-labelled nitrogen by ectomycorrhizal Pinus sylvestris plants. Agric Ecosyst Environ 28:133-137. doi: 10.1016/0167-8809(90)90028C

Forde BG, Clarkson DT (1999) Nitrate and ammonium nutrition of plants: physiological and molecular perspectives. Adv Bot Res 30:1-90. doi: 10.1016/S0065-2296(08)60226-8

Goldmann K, Schröter K, Pena R, Schöning I, Schrumpf M, Buscot F, Polle A, Wubet T (2016) Divergent habitat filtering of root and soil fungal communities in temperate beech forests. Sci Rep 6:31439. doi: 10.1038/srep31439

Grigoriev I V., Nikitin R, Haridas S, Kuo A, Ohm R, Otillar R, Riley R, Salamov A, Zhao X, Korzeniewski F, Smirnova T, Nordberg H, Dubchak I, Shabalov I (2014) MycoCosm portal: Gearing up for 1000 fungal genomes. Nucleic Acids Res 42:699-704. doi: 10.1093/nar/gkt1183

Hobbie JE, Hobbie EA (2006) $15 \mathrm{~N}$ in symbiotic fungi and plants estimates nitrogen and carbon flux rates in Arctic tundra. Ecology 87:816-822.

Kaling $M$, Schmidt A, Moritz F, Rosenkranz M, Witting $M$, Kasper K, Janz D, Schmitt-Kopplin P, Schnitzler J-P, Polle A (2018) Mycorrhiza-triggered transcriptomic and metabolomic networks impinge on herbivore fitness. Plant Physiol 176:2639-2656. doi: 10.1104/pp.17.01810

Kanehisa M, Furumichi M, Tanabe M, Sato Y, Morishima K (2017) KEGG: new perspectives on genomes, pathways, diseases and drugs. Nucleic Acids Res 45:D353-D361. doi: 10.1093/nar/gkw1092

Lang C, Polle A (2011) Ectomycorrhizal fungal diversity, tree diversity and root nutrient relations in a mixed Central European forest. Tree Physiol 31:531-538. doi:10.1093/treephys/tpr042

Langmead B, Salzberg SL (2012) Fast gapped-read alignment with Bowtie 2. Nat Methods 9:357-359. doi: 10.1038/nmeth.1923

Lareen A, Burton F, Schäfer P (2016) Plant root-microbe communication in shaping root microbiomes. Plant Mol Biol 90:575-587. doi: 10.1007/s11103-015-0417-8

LeBauer DS, Treseder KK (2008) Nitrogen limitation of net primary productivity in terrestrial ecosystems is globally distributed. Ecology 89:371-379. doi:10.1890/06-2057.1

Leberecht M, Dannenmann M, Tejedor J, Simon J, Rennenberg H, Polle A (2016) 
Segregation of nitrogen use between ammonium and nitrate of ectomycorrhizas and beech trees. Plant, Cell Environ 39:2691-2700. doi:10.1111/pce.12820

Lesur I, Bechade A, Lalanne C, Klopp C, Noirot C, Leplé J-C, Kremer A, Plomion C, Provost G Le (2015) A unigene set for European beech (Fagus sylvatica L .) and its use to decipher the molecular mechanisms involved in dormancy regulation. Mol Ecol Resour 15:1192-1204. doi: 10.1111/1755-0998.12373

Leuschner C, Ellenberg H (2017) Ecology of central Europe forests: Vegetation ecology of central Europe, Volumn I. Springer International Publishing.

Liao HL, Chen Y, Bruns TD, Peay KG, Taylor JW, Branco S, Talbot JM, Vilgalys R (2014) Metatranscriptomic analysis of ectomycorrhizal roots reveals genes associated with Piloderma - Pinus symbiosis: improved methodologies for assessing gene expression in situ. Environ Microbiol 16:3730-3742. doi: $10.1111 / 1462-2920.12619$

Love Ml, Huber W, Anders S (2014) Moderated estimation of fold change and dispersion for RNA-seq data with DESeq2. Genome Biol 15:550. doi: 10.1186/s13059-014-0550-8

Luo Z-B, Janz D, Jiang X, Göbel C, Wildhagen H, Tan Y, Rennenberg H, Feussner I, Polle A (2009) Upgrading root physiology for stress tolerance by ectomycorrhizas: Insights from metabolite and transcriptional profiling into reprogramming for stress anticipation. Plant Physiol 151:1902-1917. doi: 10.1104/pp.109.143735

Martin F, Aerts A, Ahren D, Brun A, Danchin E, Duchaussoy F, Gibon J, Kohler A, Lindquist E, Pereda V, Salamov A, Shapiro H, Wuyts J, Blaudez D, Buee M, Brokstein P, Canback B, Cohen D, Courty P, Coutinho P, Delaruelle C, Detter J, Deveau A, DiFazio S, Duplessis S, Fraissinet-Tachet L, Lucic E, Frey-Klett P, Fourrey C, Feussner I, Gay G, Grimwood J, Hoegger P, Jain P, Kilaru S, Labbe J, Lin Y, Legue V, Le Tacon F, Marmeisse R, Melayah D, Montanini B, Muratet M, Nehls U, Niculita-Hirzel H, Oudot-Le Secq M, Peter M, Quesneville H, Rajashekar B, Reich M, Rouhier N, Schmutz J, Yin T, Chalot M, Henrissat B, Kues U, Lucas S, Van de Peer Y, Podila G, Polle A, Pukkila P, Richardson P, Rouze P, Sanders I, Stajich J, Tunlid A, Tuskan G, Grigoriev I (2008) The genome of Laccaria bicolor provides insights into mycorrhizal symbiosis. Nature 452:88-93. doi: 10.1038/nature06556

Melin E, Nilsson H (1953) Transfer of labelled nitrogen from glutamic acid to Pine 
seedlings through the mycelium of Boletus variegatus (Sw.) Fr. Nature 171:134. doi: doi:10.1038/171134a0

Miller RG (1966) Simultaneous statistical inference. McGraw Hill, New York. pp6770.

Mitter B, Pfaffenbichler N, Sessitsch A (2016) Plant - microbe partnerships in 2020. Microb Biotechnol 9:635-640. doi: 10.1111/1751-7915.12382

Müller M, Seifert S, Lübbe T, Leuschner C, Finkeldey R (2017) De novo transcriptome assembly and analysis of differential gene expression in response to drought in European beech. PLoS One 12: e01841:1-20. doi: 10.1371 /journal.pone. $0184167 \% 0 \mathrm{~A}$

Olbrich M, Gerstner E, Bahnweg G, Häberle K-H, Matyssek R, Welzl G, Heller W, Ernst D (2010) Transcriptional signatures in leaves of adult European beech trees (Fagus sylvatica L.) in an experimentally enhanced free air ozone setting. Environ Pollut 158:977-982. doi:10.1016/j.envpol.2009.08.001

Olbrich M, Gerstner E, Welzl G, Winkler JB, Ernst D (2009) Transcript responses in leaves of ozone-treated beech saplings seasons at an outdoor free air model fumigation site over two growing seasons. 2009 323:61-74. doi: $10.1007 / \mathrm{s} 11104-009-0129-4$

Pena R, Offermann C, Simon J, Naumann PS, Geßler A, Holst J, Dannenmann M, Mayer H, Kögel-Knabner I, Rennenberg H (2010) Girdling affects ectomycorrhizal fungal (EMF) diversity and reveals functional differences in EMF community composition in a beech forest. Appl Environ Microbiol 76:1831-1841. doi:10.1128/AEM.01703-09

Pena R, Polle A (2014) Attributing functions to ectomycorrhizal fungal identities in assemblages for nitrogen acquisition under stress. ISME J 8(2):321-330. doi:10.1038/ismej.2013.158

Pérez-Jaramillo JE, Mendes R, Raaijmakers JM (2016) Impact of plant domestication on rhizosphere microbiome assembly and functions. Plant Mol Biol 90:635-644. doi:10.1007/s11103-015-0337-7

Plomion C, Aury J, Amselem J, Alaeitabar T, Barbe V, Belser C, Bergès $\mathrm{H}$, Bodénès C, Boudet N, Boury C, Canaguier A, Couloux A, Silva C Da, Duplessis S, Ehrenmann F, Estrada-Mairey B, Fouteau S, Francillonne N, Gaspin C, Guichard C, Klopp C, Labadie K, Lalanne C, Clainche I Le, Leplé J, Provost G Le, Leroy T, Lesur I, Martin F, Mercier J, Michotey C, Murat F, Salin F, 
Steinbach D, Faivre-Rampant P, Wincker P, Salse J, Quesneville H, Kremer A (2016) Decoding the oak genome: public release of sequence data, assembly, annotation and publication strategies. Mol Ecol Resour 16:254-265. doi: 10.1111/1755-0998.12425

R Core Team (2017) R: A language and environment for statistical computing. $R$ Foundation for Statistical Computing, Vienna, Austria. https://www.rproject.org/.

Salsac L, Sylvain C, Jean-Francois M-G, Christiane L, Eugène J (1987) Nitrate and ammonium nutrition in plants. Plant Physiol Biochem 6:805-812.

Sánchez-Cañizares C, Jorrín B, Poole PS, Tkacz A (2017) Understanding the holobiont: the interdependence of plants and their microbiome. Curr Opin Microbiol 38:188-196. doi: 10.1016/j.mib.2017.07.001

Schröter K (2015) Functional diversity of mycorrhiza in relation to land-use changes and ecosystem functions (Doctoral dissertation). https://ediss.unigoettingen.de/handle/11858/00-1735-0000-0028-86CC-1

Sebastiana M, Vieira B, Lino-neto T, Monteiro F, Figueiredo A, Sousa L, Pais MS, Tavares R, Paulo OS (2014) Oak root response to ectomycorrhizal symbiosis establishment: RNA-Seq derived transcript identification and expression profiling. Plot One 9: e98376. doi: 10.1371/journal.pone.0098376

Tuskan GA, Difazio SP, Teichmann T (2004) Poplar genomics is getting popular: The impact of the Poplar genome project on tree research. Plant Biol 6:2-4. doi: $10.1055 / \mathrm{s}-2003-44715$

Vandenkoornhuyse P, Quaiser A, Duhamel M, Le Van A, Dufresne A (2015) The importance of the microbiome of the plant holobiont. New Phytol 206:11961206. doi: $10.1111 / \mathrm{nph} .13312$ 
CHAPTER 4

ROOT-ASSOCIATED FUNGAL COMMUNITIES AND THEIR RELATIONSHIPS WITH SOIL AND ROOT NITROGEN AND CARBON AVAILABILITY IN TEMPERATE FORESTS 


\subsection{Introduction}

Root-associated fungal (RAF) communities, important components of plant microbiomes, are defined as any fungi residing in and on plant roots (Porras-Alfaro and Bayman 2011, Dean et al. 2014). To date, fungi from most phyla (Basidiomycota, Ascomycota, Glomeromycota, Chytridiomycota and Zygomycota) have been detected in RAF communities (Zhang et al. 2016, Kolaříková et al. 2017). These fungi are from different trophic groups: symbiotic fungi, root pathogens, saprotrophs, root endophytes and mycoparasites (Kernaghan 2013, Peršoh 2015). In forest ecosystems, RAF community composition of distinct host species changed significantly under human disturbance (Zhang et al. 2016), in different habitats (Goldmann et al. 2015, Vannette et al. 2016, Maghnia et al. 2017) and along a successional chronosequence (Kolaříková et al. 2017). Previous studies focused on RAF community composition of specific tree species at small scales, but little is known about changes in RAF community composition of mixed root samples at a large geographical scale. Therefore, it is of great interest to evaluate if differences in the taxonomic composition across biogeographic regions lead to changes in the functional composition of RAF communities.

Environmental factors such as soil properties (Maghnia et al. 2017), elevation (Gorzelak et al. 2012) and vegetation type (Bougoure et al. 2007) have been reported to affect RAF community structure. In soil, most of the variation in the fungal microbiome was explained by soil properties, whereas other factors (geographic location, climate, vegetation) were less important (Goldmann et al. 2016). Root-associated fungi are recruited from the surrounding soil but are less affected by the abiotic environment compared to soil fungi (Danielsen et al. 2012, Goldmann et al. 2016). RAF communities may be strongly influenced by the surrounding biotic environment, but this possibility has not yet received much attention.

It has been suggested that the coexistence of different trophic groups in plant root systems is primarily due to host plant carbon (C) partitioning (Kernaghan 2013). Therefore, carbon is expected to be a driver of RAF community structure. Symbiotic fungi generally obtain carbon from host trees in exchange for mineral nutrients while root saprotrophic fungi are supposed to live mainly on root surfaces and utilize carbon from dead root cells (Kernaghan 2013). Pathogenic fungi often obtain carbon from living root cells (Kernaghan 2013). Ectomycorrhizal abundance and diversity is driven by the carbon production of beech (Druebert et al. 2009, Pena et al. 2010). In 
boreal forests, root and RAF play an important role in the long-term carbon sequestration (Clemmensen et al. 2013). As much as 50 to $70 \%$ of stored carbon in boreal forested islands stemmed from root and root-associated microorganisms (Clemmensen et al. 2013), and the significance of RAF was stressed to contribute significantly to the regulation of $\mathrm{C}$ dynamics in boreal forests. It is also known that up to $30 \%$ of total carbon produced by forest trees through photosynthesis is supposed to be converted into RAF biomass (Kernaghan 2013). Despite the tight links of root carbon sources and associated fungal life styles, it is unknown whether differences in root pools may drive changes in RAF community structures.

Nitrogen $(\mathrm{N})$ is one of the most essential elements for tree growth and development (Lupi et al. 2013), but it is not available in sufficient quantity in a number of forest ecosystems (LeBauer and Treseder 2008). In some forest ecosystems increased nitrogen deposition leads to decreased diversity of mycorrhizal fungal communities (Lilleskov et al. 2002, 2008, Cox et al. 2010, Suz et al. 2014, de Witte et al. 2017). However, the relationships between soil and root nitrogen and RAF communities have not been addressed.

The goal of this study was to investigate the taxonomic and functional composition of RAF communities in temperate forests in relation to soil and root carbon and nitrogen pools. We hypothesized that (i) the taxonomic community compositions of RAF differ among different biogeographical regions, while the trophic community composition remains similar because of functional stability of fungal communities across three study regions; (ii) RAF communities are strongly driven by root than by soil chemistry because of host plant species effects, and (iii) different ecological groups of the RAF (symbiotroph, saprotroph, and pathotroph) respond differently to soil and root $\mathrm{C}$ and $\mathrm{N}$. To test the hypotheses, we collected soil and fine root samples from 150 forest plots in three large-scale regions of 422 to $1300 \mathrm{~km}^{2}$ (Schwäbische Alb (A), Hanich-Dün (H) and Schorfheide-Chorin (S)) located along a transect of about $700 \mathrm{~km}$ across Germany. We measured carbon-related parameters (soil and root carbon, root carbohydrates), nitrogen-related parameters (soil and root $\mathrm{N}, \mathrm{NH}_{4}{ }^{+}$and $\mathrm{NO}_{3}{ }^{-}$) and determined RAF communities using deep sequencing. 


\subsection{Materials and methods}

\subsubsection{Study site description}

This study was conducted in the Biodiversity Exploratories (http://www.biodiversityexploratories.de/startseite/) encompassing three biogeographic regions located in the south-west (Schwäbische Alb), centre (Hainich-Dün) and north-east (Schorfheide-Chorin) of Germany (Fischer et al. 2010). Key bioclimatic and geographic data have been summarized in Table 4.1. Briefly, Schwäbische Alb (A) has a cooler and moister climate than the two other regions. The soils in A are silty and have higher $\mathrm{pH}$ values than those in Hainich-Dün $(\mathrm{H})$ and Schorfheide-Chorin (S) (Table 4.1). Intermediate climate is characteristic of $\mathrm{H}$, while warm and dry conditions with sandy acidic soils characterizes the $S$ region. In each region, 50 forest plots $(100 \times 100 \mathrm{~m})$ were established. The locations of the plots can be found under http://www.biodiversity-exploratories.de/exploratories/. 
Table 4.1 Key biogeographic characteristics of three study regions. Source: (Fischer et al. 2010) with additional information about atmospheric $\mathrm{N}$ input (Schwarz et al. 2014, personal communication)

\begin{tabular}{|c|c|c|c|}
\hline & Schorfheide-Chorin (S) & Hainich-Dün $(\mathrm{H})$ & Schwäbische Alb (A) \\
\hline Location & North-east Germany & Central Germany & South-west Germany \\
\hline Size $\left(\mathrm{km}^{2}\right)$ & 1300 & 1300 & 422 \\
\hline Geology & Young glacial landscape & Calcareous bedrock & $\begin{array}{l}\text { Calcareous bedrock with karst } \\
\text { phenomena }\end{array}$ \\
\hline Altitude a.s.I. (m) & $3-140$ & $285-550$ & $460-860$ \\
\hline Longtitude east-to-west (decimal degree) & 14.14796-13.39094 & $10.77917-10.17332$ & $9.58024-9.02362$ \\
\hline Latitude north-to-south (decimal degree) & $53.22390-52.79023$ & $51.37872-50.93735$ & $48.53435-48.34996$ \\
\hline Annual mean temperature $\left({ }^{\circ} \mathrm{C}\right)$ & $8-8.5$ & $6.5-8$ & $6-7$ \\
\hline Annual mean precipitation (mm) & $500-600$ & $500-800$ & $700-1000$ \\
\hline Total $\mathrm{N}$ atmospheric input $\left(\mathrm{kg} \mathrm{ha}^{-1}\right)^{*}$ & $16.65 \pm 1.14$ & $13.84 \pm 0.84$ & $17.09 \pm 1.44$ \\
\hline $\mathrm{NO}_{3}^{-}$input $\left(\mathrm{kg} \mathrm{ha}^{-1}\right)^{*}$ & $7.48 \pm 0.51$ & $7.85 \pm 0.48$ & $10.52 \pm 0.89$ \\
\hline $\mathrm{NH}_{4}^{+}$input $\left(\mathrm{kg} \mathrm{ha}^{-1}\right)^{*}$ & $6.36 \pm 0.44$ & $4.10 \pm 0.25$ & $4.69 \pm 0.40$ \\
\hline Dissolved organic $\mathrm{N}$ input $\left(\mathrm{kg} \mathrm{ha}^{-1}\right)^{*}$ & $3.10 \pm 0.21$ & $1.89 \pm 0.12$ & $1.95 \pm 0.16$ \\
\hline
\end{tabular}

*Data for the vegetation period 2010 (end of March to beginning of November) 


\subsubsection{Root and soil sampling}

In early May 2014, 150 mineral topsoil samples $(0-10 \mathrm{~cm})$ and 150 root samples were collected in 150 forest plots. In each forest plot, two transects of $40 \mathrm{~m}$ length were established. Fourteen soil cores were taken with a split tube $(56 \mathrm{~mm}$ in diameter) along the transects, and these were taken from north to south and from west to east at the sampling points $2.5,8.5,14.5,20.5,26.5,32.5$ and $38.5 \mathrm{~m}$ from the starting points. The collected soil cores were mixed into one composite sample per plot. An aliquot of soil from the composite sample was used for element analysis. Fine roots from each composite were separated from soil, gently washed with cool tap water, and aliquots were immediately frozen in liquid nitrogen in the field and stored at $-80^{\circ} \mathrm{C}$.

\subsubsection{Analysis of root and soil carbon and nitrogen}

Fine root samples were dried at $60{ }^{\circ} \mathrm{C}$ for one week and ground to a fine powder with a ball mill (Type MM400, Retsch $\mathrm{GmbH}$, Hann, Germany). Aliquots of 0.7-1 mg were weighed into $4 \mathrm{~mm} \times 6 \mathrm{~mm}$ tin capsules (IVA Analysentechnik, Meerbusch, Germany) using a microbalance (Model: Cubis MSA 2.7S-000-DM, Sartorious, Goettingen, Germany). Samples were analyzed in an Elemental Analyzer (Model SHNC-O EA1108, Carlo Erba Instruments, Milan, Italy). Acetanilide (71.09\% C, $10.36 \% \mathrm{~N}$ ) was used as the standard for quantification of $\mathrm{N}$ and $\mathrm{C}$. Total carbon and nitrogen contents in soils were analyzed on ground subsamples by dry combustion in a CN analyzer "Vario Max" (Elementar Analysensysteme GmbH, Hanau, Germany).

\subsubsection{Analysis of non-structural carbohydrates}

Non-structural carbohydrates in fine roots were determined spectrophotometrically using an enzymatic method (Schopfer 1989). Frozen root samples were milled and extracted in dimethyl sulfoxide and $25 \% \mathrm{HCl}(80: 20, \mathrm{v}: \mathrm{v})$. A solution of glucose, fructose and sucrose (100 $\mathrm{mg} \mathrm{l}^{-1}$ per compound) was used as the reference. For the assay, the following enzymes were used: $10 \mu$ hexokinase/glucose-6-phosphate dehydrogenase $\left(3 \mathrm{mg} \mathrm{ml}^{-1}, 340 \mathrm{U}\right.$ hexokinase $\mathrm{ml}^{-1}$ and $170 \mathrm{U}$ glucose-6-phosphate dehydrogenase $\mathrm{ml}^{-1}$ at $25^{\circ} \mathrm{C}$, Roche Diagnostics $\mathrm{GmbH}$, Mannheim, Germany) for glucose determination, $5 \mu \mathrm{l}$ phosphoglucose isomerase $\left(10 \mathrm{mg} \mathrm{ml}^{-1}, 350 \mathrm{U} \mathrm{mg}^{-1}\right.$ at $25{ }^{\circ} \mathrm{C}$, Roche Diagnostics $\mathrm{GmbH}$, Mannheim, Germany) for fructose and $10 \mu \mathrm{l}$ of invertase (30 mg ml${ }^{-1}, 200-300 \mathrm{U} \mathrm{mg}^{-1}$, Sigma-Aldrich Chemie $\mathrm{GmbH}$, Steinheim, Germany) for sucrose. For starch analysis, amyloglucosidase (10 $\mathrm{mg} \mathrm{ml}^{-1}, 14 \mathrm{U} \mathrm{mg}^{-1}$ 
at $25{ }^{\circ} \mathrm{C}$, Roche Diagnostics $\mathrm{GmbH}$, Mannheim, Germany) in $50 \mu \mathrm{M}$ citrate buffer $\mathrm{pH} 4.6(1: 5, \mathrm{v}: \mathrm{v}))$ was used to convert starch to glucose and then the glucose assay was used. The enzymes were added to a $12.5 \times 12.2 \times 4.5$ disposable UV cuvette (Brand, Wertheim, Germany) containing $250 \mu$ mixture (4 mM NaDP, 10 mM ATP, 9 $\mathrm{mM} \mathrm{MgSO} 4$ and $0.75 \mathrm{M}$ triethanolamin, $\mathrm{pH}$ 7.6) and $400 \mu \mathrm{l}$ of double-distilled water and $100 \mu \mathrm{l}$ of root extract. After mixing and incubation for $5 \mathrm{~min}$ in dark, the absorbance for glucose was measured at $340 \mathrm{~nm}$ using a spectrophotometer (Type UV-DU640, Beckmann, California, USA). The obtained absorbances were used to calculate the concentrations of the carbohydrates using the following formula.

$$
\mathrm{C}\left(\mathrm{mg} \mathrm{ml}^{-1}\right)=\frac{\text { test volume }(\mathrm{ml}){ }^{*} \text { molecular weight of carbohydrate }\left(\mathrm{g} \mathrm{mol}^{-1}\right)}{\varepsilon \mathrm{NADPH}^{*} \text { cuvette thickness }(\mathrm{cm})^{*} \text { sample volume }(\mathrm{ml})} * \Delta \mathrm{E}
$$

In which, $\mathrm{C}\left(\mathrm{mg} \mathrm{ml}^{-1}\right)=$ concentration of the carbohydrate, Molecular weight of the carbohydrate $=180.16\left(\mathrm{~g} \mathrm{~mol}^{-1}\right), \varepsilon \mathrm{NADPH}=$ extinction coefficient of $\mathrm{NADPH}=6.3(\mathrm{I}$ $\left.{ }^{*} \mathrm{mmol}^{-1}{ }^{*} \mathrm{~cm}^{-1}\right), \Delta \mathrm{E}=$ the difference of the absorbances between the blank and the sample measurements, and cuvette thickness $=1(\mathrm{~cm})$.

\subsubsection{Analysis of soil and root ammonium and nitrate}

Ammonium $\left(\mathrm{NH}_{4}{ }^{+}\right)$and nitrate $\left(\mathrm{NO}_{3}{ }^{-}\right)$of soil samples were extracted from $20 \mathrm{~g}$ of fresh soil with $40 \mathrm{ml}$ of $1 \mathrm{mM} \mathrm{CaCl}$ solution. The samples were thoroughly shaken for $10 \mathrm{~min}$ and filtered for one hour using folded filter papers MN 280 (MachereyNagel, Düren, Germany). To remove all organisms, the filtrates were further filtered through a $0.2 \mu \mathrm{m}$ sterile Corning ${ }^{\circledR}$ syringe filters (CLS431218 Sigma, Sarstedt, Nümbrecht, Germany), and then kept at $-80^{\circ} \mathrm{C}$ until further analysis. The ammonium and nitrate concentrations in the filtrate were spectrophotometrically analyzed using ammonium (100683) and nitrate (109713) test kits (Merck, Darmstadt, Germany) following the manufacturer's instructions. The extinction of the assays was measured using UV-Vis spectrophotometer (Shimadzu 1601, Hannover, Germany) at $690 \mathrm{~nm}$ for $\mathrm{NH}_{4}{ }^{+}$, and $340 \mathrm{~nm}$ for $\mathrm{NO}_{3}{ }^{-}$.

Root samples of $50 \mathrm{mg}$ of frozen fine roots were extracted in $0.4 \mathrm{ml}$ of a mixture of methanol (VVA, Cologne, Germany) and chloroform (Th.Geyer $\mathrm{GmbH}$, Renningen, Germany) (3.5:1.5, v:v, Winter et al. 1992). After incubation at $40^{\circ} \mathrm{C}$ for $60 \mathrm{~min}, 0.2$ $\mathrm{ml}$ demineralized water was added to the sample solution $\left(3 \mathrm{ml} \mathrm{g}^{-1}\right)$, shaken and centrifuged for $5 \mathrm{~min}$ at $5000 \mathrm{rpm}$ (Model 5417R, Eppendorf AG, Hamburg, Germany). The above procedure of water shaking and centrifuging of the sample solution were carried out twice. The lower hydrophilic phase was collected and dried 
in a SpeedVac at $35{ }^{\circ} \mathrm{C}$. The residue was resuspended in $400 \mu \mathrm{l}$ demineralized water and centrifuged shortly at $5000 \mathrm{rpm}$ (Model 5417R, Eppendorf AG). Subsequently, ammonium and nitrate were determined spectrophotometrically using commercially available kits (Nitrate Test 109713 and Ammonium Test 100683, Merck Chemicals $\mathrm{GmbH}$, Darmstadt, Germany) according to the manufacturer's instructions. Standard curves were generated in the range from 0 to $100 \mu \mathrm{g}$ for $\mathrm{NH}_{4}{ }^{+}$ using standard solution (Test Kit 119812, Merck Chemicals $\mathrm{GmbH}$, Darmstadt, Germany) and from 0 to $1000 \mu \mathrm{g}$ for $\mathrm{NO}_{3}^{-}$(Test Kit 119811). The extinctions of sample and standard solutions were measured at $690 \mathrm{~nm}$ for $\mathrm{NH}_{4}{ }^{+}$and $340 \mathrm{~nm}$ for $\mathrm{NO}_{3}{ }^{-}$(Type UV-DU640, Beckmann, California, USA).

\subsubsection{Measuring soil $\mathrm{pH}$ and soil moisture}

Twenty-five milliliters of $0.01 \mathrm{M} \mathrm{CaCl}_{2}$ was added to $10 \mathrm{~g}$ soil. The soil $\mathrm{pH}$ was measured with a WTW pH meter 538 (Wissenschaftlich-Technische-Werkstätten $\mathrm{GmbH}$, Germany). Two measurements per sample were taken, and final value was calculated as the average value of the two measurements. To determine soil moisture, soil samples were dried at $105{ }^{\circ} \mathrm{C}$ to a constant weight. Weights were taken before and after soil drying. The percentage of water in soil was calculated as follows:

$$
\text { Soil water content }(\%)=\frac{(\text { moist soil weight-dry soil weight })}{\text { dry soil weight }} * 100
$$

\subsubsection{DNA extraction and amplification of ITS2}

Frozen samples of fine roots were ground in a ball mill (Type MM400, Retsch $\mathrm{GmbH}$, Haan, Germany). Total DNA from roots was extracted using the innuPREP Plant DNA Kit (Analytik Jena AG, Jena, Germany) according to the manufacturer's instructions. Fungal ribosomal internal transcribed spacer (ITS) region 2 was amplified with a Mastercycler Gradient (Eppendorf AG, Hamburg, Germany) using the forward primer and adapter ITS3KYO2 TCGTCGGCAGCGTCAGATGTGTATAAGAGACAGGATGAAGAACGYAGYRAA-3') (Toju et al. 2012) and the reverse primer and adapter ITS4 (5'GTCTCGTGGGCTCGGAGATGTGTATAAGAGACAGTCCTCCGCTTATTGATATG C-3') (White et al. 1990). Primers were purchased from Microsynth AG (Balgach, Switzerland). The PCR mixture (50 $\mu \mathrm{l})$ contained $30.5 \mu \mathrm{l}$ sterile nuclease-free water, $10 \mu \mathrm{l}$ X Phusion High-Fidelity buffer with $\mathrm{MgCl}_{2}, 1 \mu \mathrm{l}$ of $10 \mathrm{mM}$ dNTPs Mix, $0.5 \mu \mathrm{l}$ of

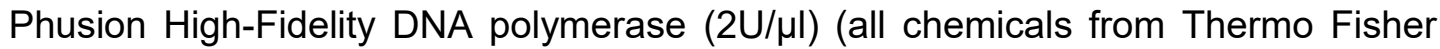
Scientific), $2.5 \mu \mathrm{l}$ of each primer $(10 \mu \mathrm{M})$ and $3 \mu \mathrm{l}$ of DNA template (diluted 1:20). 
PCR reactions were performed in triplicate under the following conditions: initial denaturation for $2 \mathrm{~min}$ at $98{ }^{\circ} \mathrm{C}$; 25 cycles of $98^{\circ} \mathrm{C}$ for $10 \mathrm{sec}, 48{ }^{\circ} \mathrm{C}$ for $20 \mathrm{sec}$ and $72{ }^{\circ} \mathrm{C}$ for $20 \mathrm{sec}$; final extension step of $5 \mathrm{~min}$ at $72{ }^{\circ} \mathrm{C}$. PCR products were checked by agarose gel electrophoresis (1.2 \% agarose, Biozym Scientific $\mathrm{GmbH}$, Hessisch Oldendorf, Germany) for appropriate size (Thermo Scientific ${ }^{\mathrm{TM}}$ GeneRuler $^{\mathrm{TM}} 1 \mathrm{~kb}$ DNA Ladder, Life Techlonogies $\mathrm{GMbH}$, Darmstadt, Germany) and purified using a magnetic bead-based Magsi-NGS ${ }^{P R E P}$ kit (Steinbrenner Laborsysteme $\mathrm{GmbH}$, Wiesenbach, Germany) according to the manufacturer's instructions. PCR pro ducts were stained using GelRed $\left(0.01 \mu \mathrm{mL}^{-1}\right.$, GelRed ${ }^{\mathrm{TM}}$ Nucleic Acid, Biotium Inc., VWR International $\mathrm{GmbH}$, Darmstadt, Germany) and visualized under ultraviolet light (Intas Science Imaging Instruments $\mathrm{GmbH}$, Göttingen, Germany). Gel running conditions were 90V for $25 \mathrm{~min}$ in an electrophoresis system (Power Pac 200, Biorad Laboratories Ltd., München, Germany). Purified PCR products were quantified using a Qubit dsDNA HS assay Kit in a Qubit 3.0 Fluorometer (Thermo Fischer Scientific, Dreieich, Germany) and pooled at equimolar concentrations for sequencing. Amplicons were sent to Göttingen Genomics Laboratory (G2L) at the Department of Microbiology and Applied Genetics in Göttingen University, Germany for sequencing using the dual index paired-end approach ( $\mathrm{v}, 2 \times 300 \mathrm{bp}$ ) for the Illumina MiSeq platform.

\subsubsection{Sequence processing and analyses}

Demultiplexing of raw sequences was performed by CASAVA data analysis software (Illumina). Paired-end sequences were merged using PEAR v0.9.10 (Zhang et al. 2014) with default parameters. Subsequently, we used Quantitative Insights into Microbial Ecology (QIIME) v1.9.1 (Caporaso et al. 2010) with the split_library_fastq.py script to remove the sequences with an average quality (Phred) score lower than 20 or containing unresolved nucleotides. For the removal of reverse and forward primer sequences, cutadapt v1.12 (Martin 2011) with default settings was applied. Before operational taxonomic unit (OTU) clustering, we employed USEARCH v9.2.64 (Edgar 2010) with the UPARSE (Edgar 2013) algorithm to remove sequences to shorter $140 \mathrm{bp}$, discard singleton reads, merge identical sequences (dereplication) and sort sequences by cluster size. Operational taxonomic units were clustered at $97 \%$ sequence identity using USEARCH. Chimeric DNA sequences were detected and removed using UCHIME2 algorithm (Edgar et al. 2011) with a reference dataset from the UNITE database Version 7.1 (Abarenkov et al. 2010) available at https://unite.ut.ee/repository.php. The merged paired-end sequences were mapped to chimera-free OTUs. The OTU table was 
generated using USEARCH. Taxonomic assignment of OTUs was performed with parallel_assign_taxonomy_blast.py against the UNITE database Version 7.2. Extrinsic domain OTUs and unclassified OTUs were removed from the data set by employing filter_otu_table_py. Finally, all unidentified fungal OTUs were BLASTed against the nt database (May 2017) to remove non-fungal OTUs, and only fungal classified reads were kept. For comparisons all samples were rarefied by random selection to the same number of reads utilizing the lowest number of sequences present in one of the samples (total 8400 reads). The OTUs were deposited under a sequence read archive (SRA) accession number SRP140604. The OTUs were assigned to functional guilds using FunGuild (Nguyen et al. 2016)

\subsubsection{Statistical analysis and calculations}

Statistical analyses were conducted using $R$ statistical software version 3.4.1 ( $R$ Core Team 2017). Data distribution and homogeneity of the variance were checked by visual inspection using histograms and residual plots. When the data did not show a normal distribution, the data were log-transformed for statistical analyses. We used ANOVA analyses to compare the means of soil and root variables among the three biogeographical regions. Generalized linear models (Poisson regression, chi-square test) were used to compare the means of count data-related variables such as fungal OTU richness and read abundance among the study regions. Pairwise differences between two study regions were compared using Tukey's Honestly Significant Difference (HSD) test. Linear mixed effects models were applied to explore the relationships between soil-and root-related variables and root fungal read abundance using function Imer() in "Ime4" package after checking assumptions and performing the selection of the best variables. Study region were included in the models as random effects. The best-fit models by Akaike's information criterion (AIC) in a stepwise algorithm, which are based on the best predictor variables, were constructed using step() function in "stats" package in R. The variance inflation factor (VIF) was used to detect the existence and severity of multicollinearity. A predictor with VIF $>10$ is considered as severe multicollinearity and was removed from models. We assessed the relative importance of predictor variables using the method developed by Lindeman, Merenda and Gold (Img) with calc.relimp() function in "relaimpo" package (Grömping 2006). Non-metric multidimensional scaling (NMDS) ordination of RAF fungal communities was conducted using function metaMDS() in "vegan" package (Oksanen et al. 2018). Data in tables and figures are shown as mean \pm standard error (SE). $P$ value $\leq 0.05$ was used to indicate a significant difference in statistical analyses. 


\subsection{Results}

\subsubsection{Soil and root chemistry varies among biogeographic regions}

Soil chemistry, soil $\mathrm{pH}$ and soil moisture differed among the three biogeographical regions (Table 4.2). Soil carbon and nitrogen were lowest in $S$ and highest in the $A$ region (Table 4.2). The soil was more acid in $S$ than in A plots. Soil moisture, which was correlated with annual mean temperature $(r=-0.53, p<0.001$, Appendix Fig. 4.1), was lower in $S$ than in the A region (Table 4.2). In contrast, the concentration of soil $\mathrm{NH}_{4}{ }^{+}$was highest in $\mathrm{S}$ and lowest in $\mathrm{A}$ region while the concentration of soil $\mathrm{NO}_{3}{ }^{-}$ exhibited the opposite order (Table 4.2).

The concentration of carbon, glucose and fructose in roots were higher in $\mathrm{S}$ than the other two regions (Table 4.2). Root starch concentrations were higher in $\mathrm{A}$ than in $\mathrm{H}$ and $S$ (Table 4.2). Root $\mathrm{N}$ concentrations were highest in A region and lowest in $S$ region. The concentrations of root $\mathrm{NO}_{3}{ }^{-}$were significantly higher in forest plots in the $\mathrm{S}$ region than the other two regions while there was no difference in root $\mathrm{NH}_{4}{ }^{+}$ among the three regions $(p=0.173$, Table 4.2). 
Table 4.2 Characterization of soil and root carbon and nitrogen, soil pH and soil moisture in three biogeographical regions. $A=S c h w a ̈ b i s c h e$ Alb, $H=$ Hainich-Dün, $S=$ Schorfheide-Chorin. Significant differences at $p \leq 0.05$ are indicated with bold letters. Data are means of $n=50$ plots per region $\pm \mathrm{SE}$

\begin{tabular}{|c|c|c|c|c|c|c|c|c|}
\hline \multirow[t]{2}{*}{ Variables } & \multirow[t]{2}{*}{ Unit } & \multicolumn{3}{|c|}{ Study region } & \multicolumn{4}{|c|}{$P$ value } \\
\hline & & A & $\mathrm{H}$ & $S$ & $\mathrm{~A}-\mathrm{H}-\mathrm{S}$ & $\mathrm{A}-\mathrm{H}$ & A-S & $\mathrm{H}-\mathrm{S}$ \\
\hline \multicolumn{9}{|l|}{ Soil variables } \\
\hline Soil C & $\mathrm{mg} \mathrm{kg}^{-1}$ & $62520 \pm 1920$ & $36850 \pm 1550$ & $19790 \pm 650$ & $<0.001$ & $<0.001$ & $<0.001$ & $<0.001$ \\
\hline Soil $N^{*}$ & $\mathrm{mg} \mathrm{kg}^{-1}$ & $4680 \pm 140$ & $2760 \pm 110$ & $1110 \pm 40$ & $<0.001$ & $<0.001$ & $<0.001$ & $<0.001$ \\
\hline Soil $\mathrm{NH}_{4}{ }^{+*}$ & $\mathrm{mg} \mathrm{kg}^{-1}$ & $0.32 \pm 0.04$ & $0.44 \pm 0.07$ & $0.67 \pm 0.06$ & $<0.001$ & 0.385 & $<0.001$ & $<0.002$ \\
\hline Soil $\mathrm{NO}_{3}^{-}$ & $\mathrm{mg} \mathrm{kg}^{-1}$ & $2.35 \pm 0.17$ & $1.31 \pm 0.10$ & $0.71 \pm 0.08$ & $<0.001$ & $<0.001$ & $<0.001$ & $<0.002$ \\
\hline Soil $\mathrm{pH}^{*}$ & & $5.23 \pm 0.10$ & $4.80 \pm 0.12$ & $3.55 \pm 0.02$ & $<0.001$ & 0.002 & $<0.001$ & $<0.001$ \\
\hline Soil moisture & $\%$ & $60.19 \pm 1.92$ & $43.57 \pm 0.99$ & $14.58 \pm 0.61$ & $<0.001$ & 0.001 & $<0.001$ & $<0.001$ \\
\hline \multicolumn{9}{|l|}{ Root variables } \\
\hline Root C & $\mathrm{mg} \mathrm{kg}^{-1}$ & $436550 \pm 5440$ & $421310 \pm 5570$ & $488360 \pm 2930$ & $<0.001$ & 0.068 & $<0.001$ & $<0.001$ \\
\hline Root glucose ${ }^{*}$ & $\mathrm{mg} \mathrm{kg}^{-1}$ & $2530 \pm 130$ & $2080 \pm 90$ & $4360 \pm 260$ & $<0.001$ & 0.058 & $<0.001$ & $<0.001$ \\
\hline Root fructose & $\mathrm{mg} \mathrm{kg}^{-1}$ & $1250 \pm 90$ & $1060 \pm 60$ & $1950 \pm 170$ & $<0.001$ & 0.471 & 0.004 & $<0.001$ \\
\hline Root starch* & $\mathrm{mg} \mathrm{kg}^{-1}$ & $4680 \pm 850$ & $1830 \pm 280$ & $3640 \pm 870$ & 0.022 & 0.019 & 0.154 & 0.651 \\
\hline Root N* & $\mathrm{mg} \mathrm{kg}^{-1}$ & $13870 \pm 450$ & $12150 \pm 260$ & $11510 \pm 340$ & $<0.001$ & 0.006 & $<0.001$ & 0.236 \\
\hline Root $\mathrm{NH}_{4}{ }^{+*}$ & $\mathrm{mg} \mathrm{kg}^{-1}$ & $29.81 \pm 3.21$ & $22.43 \pm 1.05$ & $29.57 \pm 1.98$ & 0.173 & 0.443 & 0.797 & 0.156 \\
\hline Root $\mathrm{NO}_{3}^{-}$ & $\mathrm{mg} \mathrm{kg}^{-1}$ & $1716.2 \pm 123.8$ & $1735.1 \pm 89.0$ & $2207.5 \pm 136.7$ & 0.006 & 0.993 & 0.012 & 0.017 \\
\hline
\end{tabular}

* Data were subjected to log10 transformation before ANOVA analysis 


\subsubsection{Characterization of the abundance and richness of root-associated fungi}

A total of 5030679 quality-filtered reads, which were clustered into 4765 OTUs, were present in 150 root samples from the three biogeographical regions. After removal of plant sequences, we acquired 4758344 fungal reads that were grouped into 3815 OTUs. The highest number of reads in a sample was 101929 while the lowest number was 8471 reads. On average, there were 31722 fungal reads per sample. After rarefaction to 8400 reads per sample, the data set for the comparison of rootassociated fungi consisted of 126000 reads accounting for 3366 OTUs.

Mean fungal OTU richness per plot was highest in $\mathrm{H}$ and lowest in the $\mathrm{S}$ region (Table 4.3). The total OTU richness encompassing 50 plots per region were 1913, 2230 and 1215 for $\mathrm{A}, \mathrm{H}$ and $\mathrm{S}$ regions, respectively (Appendix Fig. 4.2). Michaelis Menten Fit, which was additionally used to assess OTU richness per plot, also showed lowest fungal richness in $\mathrm{S}$ and highest in $\mathrm{H}$ (Table 4.3). Mean Shannon diversity $\left(H^{\prime}\right)$ index per plot was marginally lower in the $S$ than in the $\mathrm{H}$ region $(\mathrm{p}=0.058$, Table 4.3$)$. Evenness $\left(E_{H}\right)$ did not differ among the three study regions (Table 4.3). 
Table 4.3 Operational taxonomic unit (OTU) richness and diversity estimates of root-associated fungi in three biogeographical regions. $A=$ Schwäbische Alb, $\mathrm{H}=$ Hainich-Dün, and $S=$ Schorheide-Chorin. Differences at $p<0.05$ are indicated with bold letters. Data are means of $n$ $=50$ plots per region \pm SE. Generalized linear model (Poisson) were used for analysis of the count data (OTU richness). ANOVA was used to analyze Michaelis Menten Fit, Shannon and Evenness.

\begin{tabular}{|c|c|c|c|c|c|c|c|}
\hline \multirow[t]{2}{*}{ Parameter } & \multicolumn{3}{|c|}{ Mean \pm standard error } & \multicolumn{4}{|c|}{$p$ value } \\
\hline & $A$ & $\mathrm{H}$ & $S$ & $\mathrm{~A}-\mathrm{H}-\mathrm{S}$ & $\mathrm{A}-\mathrm{H}$ & A-S & $\mathrm{H}-\mathrm{S}$ \\
\hline OTU richness & $157 \pm 7$ & $201 \pm 8$ & $119 \pm 3$ & $<0.001$ & $<0.001$ & $<0.001$ & $<0.001$ \\
\hline Michaelis Menten Fit* & $182 \pm 9$ & $240 \pm 9$ & $135 \pm 4$ & $<0.001$ & $<0.001$ & $<0.001$ & $<0.001$ \\
\hline Shannon $\left(H^{\prime}\right)$ & $4.23 \pm 0.1$ & $4.37 \pm 0.1$ & $4.04 \pm 0.1$ & 0.072 & 0.591 & 0.382 & 0.058 \\
\hline Evenness $\left(E_{H}\right)$ & $0.85 \pm 0.0$ & $0.83 \pm 0.0$ & $0.85 \pm 0.0$ & 0.624 & 0.760 & 0.973 & 0.622 \\
\hline
\end{tabular}

* An additional method to estimate OTU richness in the three regions 


\subsubsection{Taxonomic and trophic community structures of root-associated fungi}

To explore community structure of root associated fungi, we conducted nonmetric multidimentional scaling (NMDS) analyses (Fig. 4.1). Based on the abundance of fungal taxa, the three regions were clearly separated (Fig. 4.1a). This finding was supported by ANOSIM analysis showing significant differentiation of the fungal taxa $(p<0.001, R=0.46$, Table 4.4, Fig. 4.1a). We further classified the fungal taxa according to trophic guilds. The differentiation of symbiotroph (SYM), saprotroph (SAP) and pathotroph (PAT) among different regions was less obvious than that based on taxonomy (Fig. 4.1b). Only $S$ was separated from $A$ and $H$ (Fig. 4.1b, Table 4.4). When we tested the community structures of each trophic group separately, we found that SYM and PAT showed similar separation among the three regions as the whole RAF community. SAP differed only between $\mathrm{H}$ and $\mathrm{S}$ (Table 4.4).
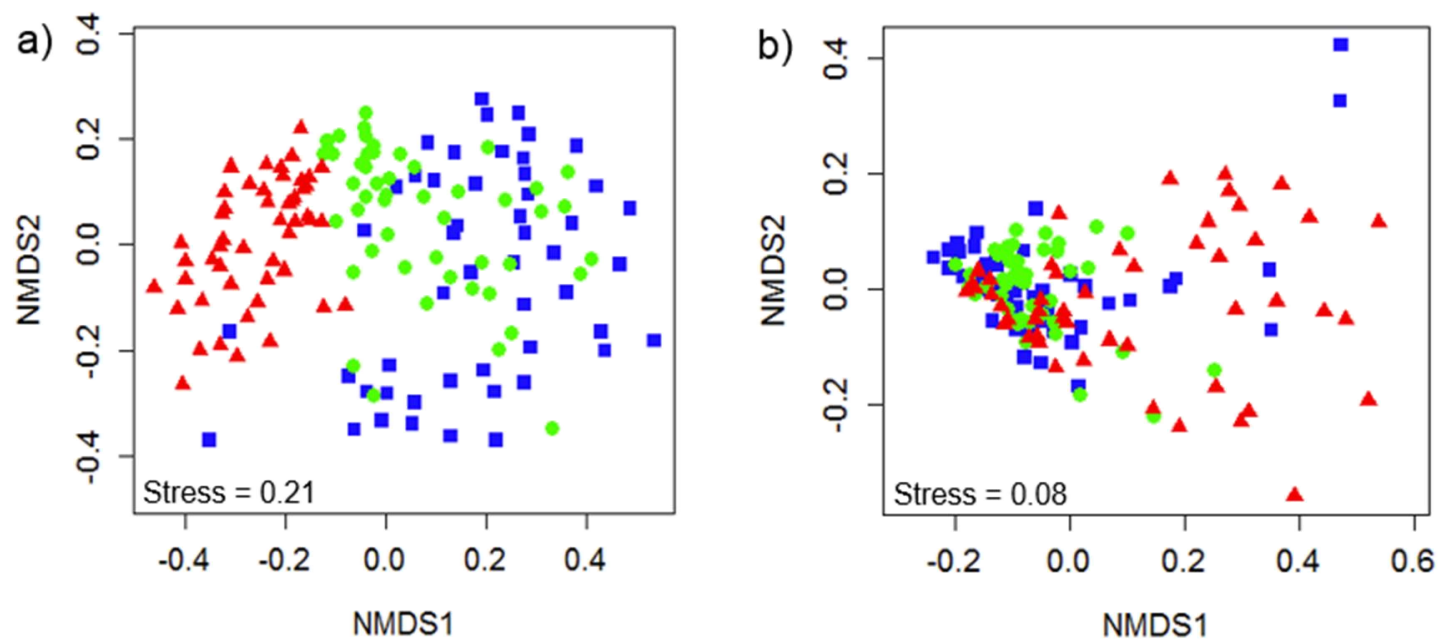

Fig. 4.1 NMDS plots by OTU taxonomic (a) and trophic (b) composition of root associated fungal communities of 150 forest plots in three regions based on Bray-

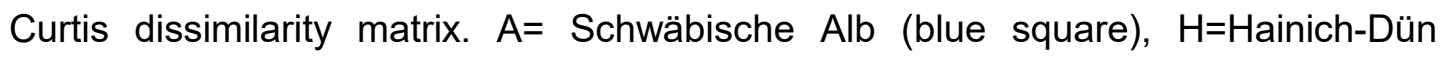
(green circle), and $S=S c h o r f h e i d e-C h o r i n$ (red triangle).

SYM were the largest group among the fungi which could be assigned to a functional guild. The abundance of SYM was lower in S ( $42 \%$ of total reads) than in A (57\%) and H $60 \%$ ) (Fig. 4.2a). About $30 \%$ of total reads could not be assigned to any trophic groups (Fig. 4.2a). Saprotrophic (SAP) and pathogenic (PAT) fungi formed the smaller groups (Fig. 4.2a). The mean abundance of trophic groups differed significantly among the three study regions (Appendix Table 4.1). The only exception were pathogens where pairwise comparison of fungal OTU richness 
between $A$ and $S$ regions did not show significant differences $(p=0.251$, Appendix Table 4.1).

Table 4.4 Similarity of root-associated fungal communities according to OTU taxonomic and trophic composition, symbiotroph (SYM), saprotroph (SAP) and pathotroph (PAT) among the three biogeographical regions. $A=$ Schwäbische Alb, $\mathrm{H}=$ Hainich-Dun and $\mathrm{S}=$ Schorfheide-Chorin .

\begin{tabular}{lllllll}
\hline \multicolumn{1}{c}{} & $\begin{array}{l}\text { OTU } \\
\text { taxonomic } \\
\text { composition }\end{array}$ & $\begin{array}{l}\text { Trophic } \\
\text { composition }\end{array}$ & SYM & SAP & PAT \\
\hline p value & All regions & $\mathbf{< 0 . 0 0 1}$ & $\mathbf{< 0 . 0 0 1}$ & $\mathbf{< 0 . 0 0 1}$ & $<0.05$ & $<0.001$ \\
& A-H & $\mathbf{< 0 . 0 0 1}$ & 0.114 & 0.131 & 0.845 & 0.132 \\
& A-S & $\mathbf{< 0 . 0 0 1}$ & $<0.001$ & $<0.01$ & 0.060 & $<0.001$ \\
R value & H-S & $<0.001$ & $<0.001$ & $<0.001$ & $\mathbf{0 . 0 3 5}$ & $<0.001$ \\
& All regions & 0.460 & 0.111 & 0.095 & 0.031 & 0.211 \\
& A-H & 0.166 & 0.023 & 0.023 & 0.003 & 0.030 \\
& A-S & 0.687 & 0.135 & 0.093 & 0.040 & 0.354 \\
& H-S & 0.468 & 0.187 & 0.177 & 0.047 & 0.246 \\
\hline
\end{tabular}

Data show $p$ and $R$ values after ANOSIM based on Bray-Curtis measure. $p$ values $\leq$ 0.05 are shown in bold

Taxonomic composition according to phyla and orders varied among the three study regions (Fig. 4.2b, Appendix Table 4.2). The most dominant phylum in all three regions was that of Basidiomycota, accounting for $77 \%, 79 \%$ and $64 \%$ of total reads for A, $\mathrm{H}$ and S, respectively (Fig. 4.2b, Appendix Table 4.2). The second common phylum was that of Ascomycota, with $14 \%$ of total reads in $\mathrm{A}, 14 \%$ in $\mathrm{H}$ and $29 \%$ in $S$ (Fig. 4.2b, Appendix Table 4.2). Approximately $5 \%$ of the sequences could not be assigned to any fungal order. The remaining fungal reads stemmed from two small phyla, Zygomycota and Chytridiomycota, with less than $0.5 \%$ of total reads in each region (Fig. 4.2b, Appendix Table 4.2). Two most abundant orders within Basidiomycota were Agaricales and Russulales, accounting for between 50\% and $56 \%$ of total fungal reads (Fig. $4.2 \mathrm{~b}$ ). The most abundant fungal order in the phylum of the Ascomycota were Helotiales which made up to $20 \%$ of total reads in S, compared to $7 \%$ in $A$ and $5 \%$ in $S$ region (Fig. 4.2b, Appendix Table 4.2). We found that Agaricales and Russulales forming mycorrhizas were dominant in $\mathrm{A}, \mathrm{H}$ and in $\mathrm{S}$ (Fig. 4.2b, Appendix Table 4.2). 

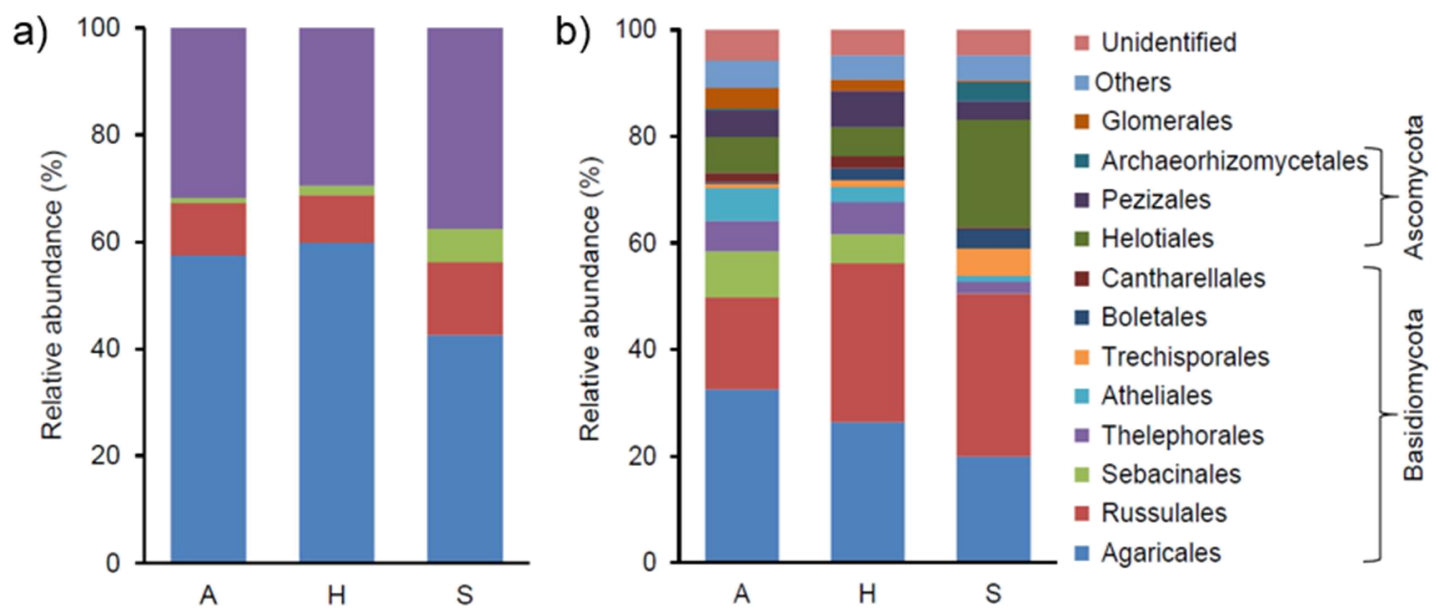

Fig. 4.2 Relative abundance of root-associated fungal communities in three study regions. The abundance of trophic groups (a), blue=symbiotroph, red=saprotroph, green=pathotroph, purple=unknown. The OTU taxonomic orders (b), fungal orders with a relative abundance $<1 \%$ were grouped in Others. $A=S$ chwäbische $A l b, H=$ Hainich-Dün, and $S$ = Schorfheide-Chorin.

\subsubsection{Drivers for the changes in root-associated fungal communities in three}

\section{biogeographic regions}

We tested whether the abundance of SYM, SAP or PAT were driven by soil- or rootrelated properties. We found that root $\mathrm{NO}_{3}{ }^{-}$was positively correlated with $\mathrm{SYM}$ and negatively correlated to SAP and PAT (Fig. 4.3a). In contrast to root $\mathrm{NO}_{3}{ }^{-}$, root $\mathrm{NH}_{4}{ }^{+}$ was negatively correlated to SYM, but positively correlated with SAP or PAT abundances (Fig. 4.3a). As a result, all of the trophic groups were driven by root $\mathrm{NH}_{4}{ }^{+}$and $\mathrm{NO}_{3}{ }^{-}$but in a contrasting manner (Fig. 4.3a). Root glucose was positively correlated to SAP and negatively correlated to PAT (Fig. 4.3a). Soil water content was positively correlated to SYM, but negatively to SAP and not correlated to PAT (Table 4.3a). SYM responded positively to soil $\mathrm{NH}_{4}{ }^{+}$but negatively to soil $\mathrm{pH}$ while SAP and PAT showed no responses to the factors (Table 4.3a). Regarding the relative importance of soil and root variables, soil water content and study site were important, explaining over $20 \%$ and $30 \%$ variances for SYM and PAT respectively (Fig. 4.3b). For SYM and SAP, the proportion of variance explained by root-related variables was higher than by soil-related variables (Fig 4.3b). Therefore, across the whole biogeographic range studied here, carbon and nitrogen in roots were the most important variables in explaining changes in the fungal groups than those elements in soil (Fig. 4.3b). However, within a distinct region these clear relationships were not observed anymore (Appendix Fig. 4.3). 
a)

\begin{tabular}{|c|c|c|c|}
\hline SYM & SAP & PAT & \\
\hline 0.044 & & & Soil NH4 \\
\hline 0.041 & & & Soil pH \\
\hline 0.026 & 0.041 & & Soil water \\
\hline & 0.019 & 0.010 & Root glucose \\
\hline 0.000 & 0.014 & 0.013 & Root NH4 \\
\hline 0.000 & 0.000 & 0.003 & Root NO3 \\
\hline
\end{tabular}

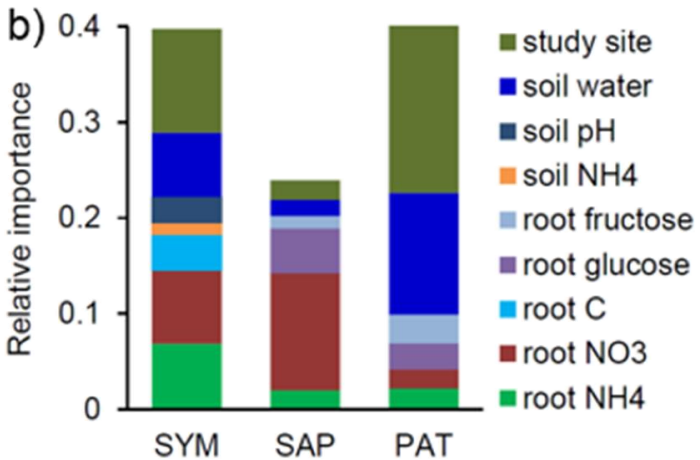

Fig. 4.3 Significant relationships between the abundance of trophic groups and soil or root chemistry (a) and relative importance of abiotic variables to trophic fungal groups (b) in the three biogeographical regions. SYM=symbiotroph, $\mathrm{SAP}=$ saprotroph, $\mathrm{PAT}=$ pathotroph. Blue colors in (a) indicate negative correlations while red colors stand for positive correlations. $P$ values were shown numerically where significant effects were found.

Since the fungal composition changed among the regions, we wondered whether the divergent behavior within and among the regions might have been caused by different effects of environmental drivers on phylogenetically different fungi. To address this question, we explored the relationships of fungal orders with soil- and root-related factors. Different fungal orders showed specific response patterns to soil and root chemistry, soil pH and soil moisture (Fig. 4.4a). Root $\mathrm{NO}_{3}{ }^{-}$was related to seven out of ten fungal orders which contain $76 \%$ of the total fungal sequences (Fig. 4.4a). Other important drivers were soil pH and soil water (Fig. 4.4a). Soil pH was significantly related to five fungal orders accounting for $41 \%$ of the total sequences while soil water was correlated to four fungal orders with $42 \%$ of the total sequences. Study site contributed to the explained variances of all fungal orders, with more than $20 \%$ of the variance for each of the Helotiales and Sebacinales (Fig. $4.4 \mathrm{~b})$. Soil $\mathrm{pH}$ and water content explained a majority of variances of several fungal orders such as Sebacinales (45\%), Trechisporales (38\%) and Helotiales (30\%) (Fig. 4.4b). Root $\mathrm{NO}_{3}{ }^{-}$is important for Glomerales, explaining $30.3 \%$ of variance for changes of the fungal order (Fig. 4.4b). Other root and soil variables contributed to less than $10 \%$ of variance for changes in the fungal orders (Fig. 4.4b).

Furthermore, we compared whether closely related orders are more similarly influenced by soil and root factors (Fig. 4.4a,b). Helotiales and Pezizales, which are from subphylum Pezizomycotina (Hibbett et al. 2007), showed different responses to the environmental factors. Helotiales was much stronger related to soil factors and study site than Pezizales (Fig. 4.4a,b). Glomerales, which is from Glomeromycota, 
showed a distinct behavior compared to other orders (Fig 4.4a,b). We did not find the similar response for the rest of 7 fungal orders (Fig. 4.4a,b) which belongs to the same taxa of Agaricomycotina (Hibbett et al. 2007). At a deeper classification level, Agaricales, Atheliales and Boletales, belonging to Agaricomycetidae, showed no similar responses (Fig. 4.4a,b). As a result, we found no phylogenetic relationships in relation to similar responses of root-associated fungi to abiotic factors.

a)

\begin{tabular}{|c|c|c|c|c|c|c|c|c|c|c|}
\hline Agar & Athe & Bole & Russ & Thel & Trec & Seba & Pezi & Helo & Glom & \\
\hline & 0.001 & & & & & & & & 0.008 & Soil N \\
\hline & 0.004 & & & & & & & & & Soil NH4 \\
\hline & & 0.019 & & & & & 0.007 & & & Soil NO3 \\
\hline & 0.017 & & 0.000 & 0.006 & 0.000 & 0.000 & & & & Soil pH \\
\hline 0.000 & & 0.027 & & & 0.045 & & & 0.000 & & Soil water \\
\hline & 0.008 & & & & & 0.010 & & & & Root C \\
\hline & 0.013 & & & & & & & & & Root fructose \\
\hline & 0.000 & 0.000 & & & & 0.005 & & & 0.015 & Root starch \\
\hline 0.010 & & 0.011 & & & & & 0.028 & & & Root N \\
\hline & & & 0.000 & & & & & 0.043 & & Root NH4 \\
\hline 0.003 & 0.001 & 0.013 & 0.000 & & & & 0.002 & 0.015 & 0.000 & Root $\mathrm{NO}_{3}$ \\
\hline
\end{tabular}

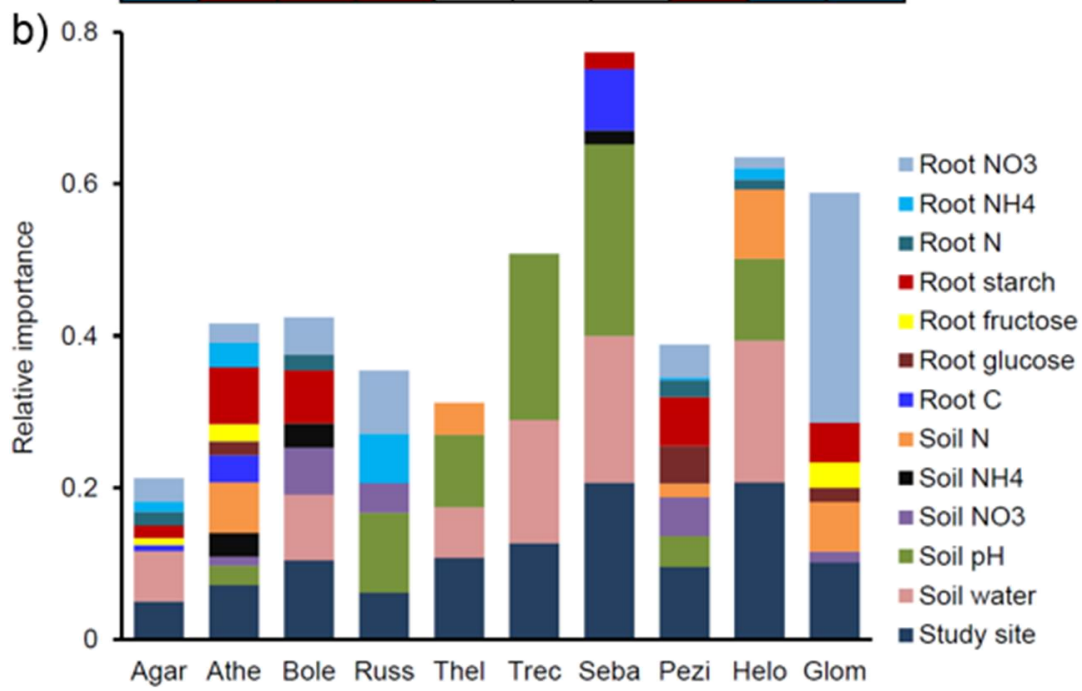

Fig. 4.4 Significant relationships between the abundance of root-associated fungal orders and soil and root chemistry (a) and relative importance of abiotic variables to taxonomic fungal orders (b) in the three study regions. Orders with a relative abundance $>2 \%$ were included in the analysis. Blue colors in (a) indicate negative correlations while red colors stand for positive correlations. $P$ values were represented numerically where significant effects were found. Agar=Agaricales, Athe $=$ Atheliales, Bole=Boletales, Russ=Russulales, Thel=Thelephorales, Trec $=$ Trechisporales, Seba $=$ Sebacinales, Pezi $=$ Pezizales, Helo=Helotiales, Glom=Glomerales. 


\subsection{Discussion}

\subsubsection{Differentiation in taxonomic and trophic communities of root-associated}

fungi across the three biogeographical regions

A strong differentiation of RAF communities among the three biogeographical regions (Fig. 4.1, Table 4.4) is in agreement with our hypothesis that differences in soil and root chemistry at each studied region lead to different RAF community assemblages. The taxonomic dissimilarity of RAF communities could be explained by differences in composition of soil fungal communities in the three study regions. This result is supported by previous studies on the same sampling system. It was reported that RAF communities are inherited from soil fungal communities, and that fungal community structures in soil differ significantly across temperate forest ecosystems (Wubet et al. 2012, Goldmann et al. 2015, 2016). Furthermore, the difference in tree species composition among the three study regions. In our sampling plot systems, there are pine plots in $\mathrm{S}$ but not in $\mathrm{A}$ and $\mathrm{H}$ regions whereas spruce plots occur in $\mathrm{A}$ and $\mathrm{H}$ but not in $\mathrm{S}$ region. In our study, difference in composition of trophic groups are less strong than the taxonomic composition, and no difference in the composition of tropic groups between $A$ and $H$ was observed (Fig. 4.1b, Table 4.4). This result suggests that functional resilience of RAF communities can still be achieved by taxonomic divergence between $A$ and $H$, however, it cannot be obtained between $S$ and the other two biogeographic regions.

We found Basidiomycota being the most abundant fungal phyla in RAF communities following by Ascomycota (Fig. 4.2b, Appendix Table 4.2), although Ascomycota is the largest phylum in the fungal kingdom (James et al. 2006, Beimforde et al. 2014). This result is in agreement with previous studies which investigated root and soil fungal communities in forest ecosystems (Mathiesen and Ohlson 2008, Wubet et al. 2012, McGuire et al. 2013, Goldmann et al. 2015, 2016, de Witte et al. 2017, Philpott et al. 2018). The reason for this is possibly explained by the contribution of ectomycorrhizal communities, which are more dominant members of the Basidiomycota than Ascomycota (Smith and Read 2008), in temperate forests (Goldmann et al. 2015).

Our results showed that there was a significant difference in mean read abundance of trophic groups per plot among three study regions (Appendix Table 4.1), and SYM is the most abundant group compared to SAP and PAT (Fig. 4.2a, Appendix Table 4.1). This is consistent with earlier finding suggesting that the abundance of 
ecological guilds differed a cross an elevational gradient in temperate forests (Veach et al. 2017) and the abundance of ectomycorrhizal fungi is dominant compared to pathogenic and endophytic fungi in the roots of two tree species Salix caprea and Betula pendula (Kolaříková et al. 2017). Similarly, ectomycorrhizal fungi were found to be dominant in our results. This is in agreement with previous observations on mycorrhizas in top soil in the same sampling system, where richness and diversity of ectomycorhizal communities, investigated by DNA sequencing from ectomycorrhizal root tips, is lowest in S compared to the other two study regions (Pena et al. 2017). However, a more recent study in oak, beech and spruce temperate forests reported that saprotrophic fungi were dominant, accounting for $67 \%$ of fungal sequences in litter and $53 \%$ in soil whereas percentages of ectomycorrhizal fungi were $3 \%$ of fungal sequences in litter and $36 \%$ in soil (Bahnmann et al. 2018). We suggest that the composition of guilds is determined by habitat as the compositions of trophic groups are different from those of soil and litter. High abundance of SYM in this study may be because of that unlike litter and soil, there are more symbiotic fungi, especially ectomycorrhizal fungi associated with forest tree root systems (Kolaříková et al. 2017).

Furthermore, we found the most abundance of PAT and SAP in S compared to the other two regions (Fig. 4.2a). This is possibly due to the fact that the abundance of dead root tips is significantly different among the three regions, with the highest amount being in $S$ and the lowest in the $A$ plots (Appendix Fig. 4.4). Higher abundance of dead root tips in $S$ are possibly related to environmental factors because soils are more acid and less moist in $S$ than the other regions (Table 4.2). However, we found no relations between soil $\mathrm{pH}$ and soil water content and the abundance of death root tips. We suggested that fungal pathogens in roots could play a role in this situation.

\subsubsection{Root and soil factors correlated with trophic and taxonomic groups of root-associated fungi}

Previous studies reported that $\mathrm{C} / \mathrm{N}$ ratio is of importance for RAF communities (Maghnia et al. 2017) and soil fungal communities (Wubet et al. 2012, Goldmann et al. 2015). Because of the importance of carbon and nitrogen exchange in RAF-plant interactions, and to further understand the interaction at a biogeographical scale we investigated the relationships of RAF communities with a number of $\mathrm{C}$ - and $\mathrm{N}$ related variables in both roots and soils. 
We found that trophic groups responded differently to root and soil carbon and nitrogen variables (Fig. 4.3a), and this is in line with our expectation. In our study, root $\mathrm{NH}_{4}^{+}$and root $\mathrm{NO}_{3}^{-}$were significantly related to SYM, SAP and PAT and contributed to large explained variance for changes in SYM and SAP (Fig. 4.3a, b). Previous studies focused on the relationships of abiotic factors with the whole fungal communities and mycorrhizal fungi. For example, soil $\mathrm{pH}$ and $\mathrm{C} / \mathrm{N}$ ratio were reported to be drivers for both soil and root fungal communities as the whole (Wubet et al. 2012, Maghnia et al. 2017). Other studies in forest ecosystems found negative relationships of nitrogen input and ectomycorrhizal communities (De Witte et al. 2017, Suz et al. 2014, Lilleskov et al. 2002). We showed that carbon and nitrogen in roots were more important than those in soil for the trophic groups (Fig. 4.3a, b). This finding can be explained by control of RAF communities by host trees than by soil chemistry. For example, it is suggested that host plants in temperate forests make RAF communities more stable than soil fungal communities (Goldmann et al. 2016).

Generally, different fungal orders responded distinct patterns to the abiotic variables (Fig. 4.4a) which is consistent with our hypothesis. In our study, root $\mathrm{NO}_{3}{ }^{-}$, soil $\mathrm{pH}$ and water were important drivers for root-associated fungal orders. (Fig. 4.4a,b). Among those, soil $\mathrm{pH}$ has been commonly shown to be a driver for changes in soil and root fungal communities (Suz et al. 2014, Goldmann et al. 2015, Bahnmann et al. 2018). In another study, however, soil $\mathrm{pH}$ was significantly related to the whole fungal community, especially in the Pezizomycota and Agaricomycota, and was also correlated to ectomycorrhizal genera such as Inocybe, Phialophora and Sebacina (Wubet et al. 2012). In the present study, in general, the different relationship patterns of fungal order can be explained by the preference of different orders to different environmental conditions. The order Agaciales, which was positively correlated to soil water and negatively correlated to root $\mathrm{NO}_{3}^{-}$(Fig. 4.4a), tends to reside under the conditions of higher moisture and lower concentration of root $\mathrm{NO}_{3}^{-}$ in $\mathrm{A}$ than in $\mathrm{H}$ and $\mathrm{S}$ plots (Appendix Table 4.2). Similarly, Russulales, negatively correlated with soil $\mathrm{pH}$ and positively correlated to root $\mathrm{NO}_{3}^{-}$(Fig. 4.4a), prefers to reside under lower $\mathrm{pH}$ and higher root $\mathrm{NO}_{3}{ }^{-}$in $\mathrm{S}$ than the other two regions (Appendix Table 4.2). Helotiales, the most abundant order of Ascomycota in our study and negatively correlated to soil water, has more sequence abundance in drier $\mathrm{S}$ region than $\mathrm{H}$ and $\mathrm{A}$ (Fig. 4.4a). This order had more abundance in $\mathrm{S}$ region although it was negatively related to root $\mathrm{NO}_{3}{ }^{-}$. Root $\mathrm{NO}_{3}{ }^{-}$could be of minor importance to Helotiales because root $\mathrm{NO}_{3}{ }^{-}$only explained $1.4 \%$ variance for 
changes in Helotiales communities (Fig. 4.4b). The different proportion of trophic groups in the same order cannot explain the difference in response patterns of fungal orders to abiotic variables. In our study, Russulales (99.9\% SYM sequences) and Boletales (88\% SYM, 0.4\% SAP and 0\% PAT, 11.8 UNK), had more abundance in $S$ than in A region. In contrast, Glomerales (100\% SYM) and Sebacinales (82.8\% SYM, 17.2 UNK sequences) occurred more in $A$ than in $S$ and $H$, this trend is also true for other orders of Thelephorales and Atheliales. For orders containing both SYM and SAP, Helotiales (16.9\% SYM, 17.1\% SAP, 2.2\% PAT, 63.7\% UNK) had more sequence abundance in $\mathrm{S}$ than in $\mathrm{A}$ and $\mathrm{H}$ region; however, Pezizales $(54.7 \%$ SYM, 36.2\% SAP, 0\% PAT and 9.1\% UNK) was more abundant in $\mathrm{A}$ and $\mathrm{H}$ than in $\mathrm{S}$ regions. Overall, the results indicated that soil $\mathrm{pH}$, soil moisture and root $\mathrm{NO}_{3}{ }^{-}$ were the most important drivers for the changes in root fungal orders, and that phylogenetically different fungi responded differently to abiotic factors in roots and soils.

\subsection{References}

Abarenkov K, Nilsson RH, Larsson K-H, Alexander IJ, Eberhardt U, Erland S, Høiland K, Kjøller R, Larsson E, Pennanen T, Sen R, Taylor AFS, Tedersoo L, Ursing BM, Vralstad T, Liimatainen K, Peintner U, Koljalg U (2010) The UNITE database for molecular identification of fungi-recent updates and future perspectives. New Phytol 186:281-285. doi: 10.1111/j.14698137.2009.03160.x

Bahnmann B, Tereza Mašínová, Halvorsen R, L.Davey M, Sedlák P, Tomšovský M, Baldrian P (2018) Effects of oak, beech and spruce on the distribution and community structure of fungi in litter and soils across a temperate forest. Soil Biol Biochem 119:162-173. doi: 10.1016/j.soilbio.2018.01.021

Beimforde C, Feldberg K, Nylinder S, Rikkinen J, Tuovila H, Dörfelt H, Gube M, Jackson DJ, Reitner J, Seyfullah LJ, Schmidt AR (2014) Estimating the Phanerozoic history of the Ascomycota lineages: Combining fossil and molecular data. Mol Phylogenet Evol 78:386-398. doi: 10.1016/j.ympev.2014.04.024

Bougoure DS, Parkin PI, Cairney JWG, Alexander IJ, Anderson IC (2007) Diversity of fungi in hair roots of Ericaceae varies along a vegetation gradient. Mol Ecol 16:4624-4636. doi: 10.1111/j.1365-294X.2007.03540.x

Caporaso JG, Kuczynski J, Stombaugh J, Bittinger K, Bushman FD, Costello EK, 
Fierer N, Peña AG, Goodrich K, Gordon JI, Huttley GA, Kelley ST, Knights D, Jeremy E, Ley RE, Lozupone CA, Mcdonald D, Muegge BD, Reeder J, Sevinsky JR, Turnbaugh PJ, Walters WA (2010) QIIME allows analysis of highthroughput community sequencing data. Nat Methods 7:335-336. doi: 10.1038/nmeth.f.303.QIIME

Clemmensen KE, Bahr A, Ovaskainen O, Dahlberg A, Ekblad A, Wallander $H$, Stenlid J, Finlay RD, Wardle DA, Lindahl BD (2013) Roots and associated fungi drive long-term carbon sequestration in boreal forest. Science 339:1615-1618. doi: $10.1126 /$ science. 1231923

Danielsen L, Thürmer A, Meinicke P, Buée M, Morin E, Martin F, Pilate G, Daniel R, Polle A, Reich M (2012) Fungal soil communities in a young transgenic poplar plantation form a rich reservoir for fungal root communities. Ecol Evol 2:19351948. doi: $10.1002 /$ ece 3.305

Dean SL, Farrer EC, Lee Taylor D, Porras-Alfaro A, Suding KN, Sinsabaugh RL (2014) Nitrogen deposition alters plant-fungal relationships: linking belowground dynamics to aboveground vegetation change. Mol Ecol 23:13641378. doi: $10.1111 / \mathrm{mec} .12541$

Druebert C, Lang C, Valtanen K, Polle A (2009) Beech carbon productivity as driver of ectomycorrhizal abundance and diversity. Plant, Cell Environ 32:992-1003. doi: 10.1111/j.1365-3040.2009.01983.x

Edgar RC (2010) Search and clustering orders of magnitude faster than BLAST. Bioinformatics 26:2460-2461. doi:10.1093/bioinformatics/btq461

Edgar RC (2013) UPARSE: highly accurate OTU sequences from microbial amplicon reads. Nat Methods 10:996-998. doi: 10.1038/nmeth.2604

Edgar RC, Haas BJ, Clemente JC, Quince C, Knight R (2011) UCHIME improves sensitivity and speed of chimera detection. Bioinformatics 27:2194-2200. doi: 10.1093/bioinformatics/btr381

Fischer M, Bossdorf O, Gockel S, Hänsel F, Hemp A, Hessenmöller D, Korte G, Nieschulze J, Pfeiffer S, Prati D, Renner S, Schöning I, Schumacher U, Wells K, Buscot F, Kalko EK V, Linsenmair KE, Schulze E, Weisser WW (2010) Implementing large-scale and long-term functional biodiversity research: The Biodiversity Exploratories. Basic Appl Ecol 11:473-485. doi: 10.1016/j.baae.2010.07.009

Goldmann K, Schöning I, Buscot F, Wubet T (2015) Forest management type 
influences diversity and community composition of soil fungi across temperate forest ecosystems. Front Microbiol 6:1300. doi: 10.3389/fmicb.2015.01300

Goldmann K, Schröter K, Pena R, Schöning I, Schrumpf M, Buscot F, Polle A, Wubet $T$ (2016) Divergent habitat filtering of root and soil fungal communities in temperate beech forests. Sci Rep 6:31439. doi: 10.1038/srep31439

Gorzelak MA, Hambleton S, Massicotte HB (2012) Community structure of ericoid mycorrhizas and root-associated fungi of Vaccinium membranaceum across an elevation gradient in the Canadian Rocky Mountains. Fungal Ecol 5:36-45. doi: 10.1016/j.funeco.2011.08.008

Grömping U (2006) Relative importance for linear regression in R: The Package relaimpo. J Stat Softw 17:1-27. doi: 10.18637/jss.v017.i01

Hibbett DS, Binder M, Bischoff JF, Blackwell M, Cannon PF, Eriksson OE, Huhndorf S, James T, Kirk PM, Lücking R, Thorsten Lumbsch H, Lutzoni F, Matheny PB, McLaughlin DJ, Powell MJ, Redhead S, Schoch CL, Spatafora JW, Stalpers JA, Vilgalys R, Aime MC, Aptroot A, Bauer R, Begerow D, Benny GL, Castlebury LA, Crous PW, Dai YC, Gams W, Geiser DM, Griffith GW, Gueidan C, Hawksworth DL, Hestmark G, Hosaka K, Humber RA, Hyde KD, Ironside $\mathrm{JE}$, Kõljalg $\mathrm{U}$, Kurtzman $\mathrm{CP}$, Larsson $\mathrm{KH}$, Lichtwardt R, Longcore J, Miadlikowska J, Miller A, Moncalvo JM, Mozley-Standridge S, Oberwinkler F, Parmasto E, Reeb V, Rogers JD, Roux C, Ryvarden L, Sampaio JP, Schüßler A, Sugiyama J, Thorn RG, Tibell L, Untereiner WA, Walker C, Wang Z, Weir A, Weiss M, White MM, Winka K, Yao YJ, Zhang N (2007) A higher-level phylogenetic classification of the Fungi. Mycol Res 111:509-547. doi: 10.1016/j.mycres.2007.03.004

James TY, Kauff F, Schoch CL, Matheny PB, Hofstetter V, Cox CJ, Celio G, Gueidan C, Fraker E, Miadlikowska J, Lumbsch HT, Rauhut A, Reeb V, Arnold AE, Amtoft A, Stajich JE, Hosaka K, Sung G-H, Johnson D, O'Rourke B, Crockett M, Binder M, Curtis JM, Slot JC, Wang Z, Wilson AW, Schüßler A, Longcore JE, O'Donnell K, Mozley-Standridge S, Porter D, Letcher PM, Powell MJ, Taylor JW, White MM, Griffith GW, Davies DR, Humber RA, Morton JB, Sugiyama J, Rossman AY, Rogers JD, Pfister DH, Hewitt D, Hansen K, Hambleton S, Shoemaker RA, Kohlmeyer J, Volkmann-Kohlmeyer B, Spotts RA, Serdani M, Crous PW, Hughes KW, Matsuura K, Langer E, Langer G, Untereiner WA, Lücking R, Büdel B, Geiser DM, Aptroot A, Diederich P, Schmitt I, Schultz M, Yahr R, Hibbett DS, Lutzoni F, McLaughlin DJ, Spatafora 
JW, Vilgalys R (2006) Reconstructing the early evolution of Fungi using a sixgene phylogeny. Nature 443:818-822. doi: 10.1038/nature05110

Kauserud H, Mathiesen C, Ohlson M (2008) High diversity of fungi associated with living parts of boreal forest bryophytes. Bo 86:1326-1333. doi: 10.1139/B08102

Kernaghan G (2013) Functional diversity and resource partitioning in fungi associated with the fine feeder roots of forest trees. Symbiosis 61:113-123. doi: 10.1007/s13199-013-0265-8

Kolařiková Z, Kohout P, Krüger C, Janoušková M, Mrnka L, Rydlová J (2017) Rootassociated fungal communities along a primary succession on a mine spoil: Distinct ecological guilds assemble differently. Soil Biol Biochem 113:143-152. doi: 10.1016/j.soilbio.2017.06.004

LeBauer DS, Treseder KK (2008) Nitrogen limitation of net primary productivity in terrestrial ecosystems is globally distributed. Ecology 89:371-379. doi: 10.1890/06-2057.1

Lilleskov EA, Fahey TJ, Horton TR, Lovett GM (2002) Belowground ectomycorrhizal fungal community change over a nitrogen deposition gradient in Alaska. Ecology 83:104-115. doi: 10.1890/00129658(2002)083[0104:BEFCCO]2.0.CO;2

Lilleskov EA, Wargo PM, Vogt KA, Vogt DJ (2008) Mycorrhizal fungal community relationship to root nitrogen concentration over a regional atmospheric nitrogen deposition gradient in the northeastern USA. Can J For Res 38:1260-1266. doi: $10.11391 \times 07-211$

Lupi C, Morin H, Deslauriers A, Rossi S, Houle D (2013) Role of soil nitrogen for the conifers of the boreal forest: A critical review. Int J Plant Soil Sci 2:155-189. doi:10.9734/IJPSS/2013/4233

Maghnia FZ, Abbas Y, Mahé F, Kerdouh B, Tournier E, Ouadji M, Tisseyre P, Prin Y, Ghachtouli N El, Yakhlef SEB, Duponnois R, Sanguin H (2017) Habitat-and soil-related drivers of the root- associated fungal community of Quercus suber in the Northern Moroccan forest. PLoS One 12: e01877. doi: 10.1371/journal.pone.0187758

Martin M (2011) Cutadapt removes adapter sequences from high-throughput sequencing reads. EMBnet.journal 17:10-12. doi: 10.14806/ej.17.1.200

McGuire KL, Allison SD, Fierer N, Treseder KK (2013) Ectomycorrhizal-dominated 
boreal and tropical forests have distinct fungal communities, but analogous spatial patterns across soil horizons. PLoS One 8: doi: 10.1371/journal.pone.0068278

Nguyen NH, Song Z, Bates ST, Branco S, Tedersoo L, Menke J, Schilling JS, Kennedy PG (2016) FUNGuild: An open annotation tool for parsing fungal community datasets by ecological guild. Fungal Ecol 20:241-248. doi: 10.1016/j.funeco.2015.06.006

Oksanen J, Blanchet FG, Friendly M, Kindt R, Legendre P, Mcglinn D, Minchin PR, O'Hara RB, Simpson GL, Solymos P, Stevens MHH, Szoecs E, Wagner H (2018) vegan: Community Ecology Package. R package version 2.4-4. https://CRAN.R-project.org/package=vegan.

https://cran.rproject.org/package=vegan

Pena R, Lang C, Lohaus G, Boch S, Schall P, Schöning I, Ammer C, Fischer M, Polle A (2017) Phylogenetic and functional traits of ectomycorrhizal assemblages in top soil from different biogeographic regions and forest types. Mycorrhiza 27:233-245. doi:10.1007/s00572-016-0742-z

Pena R, Offermann C, Simon J, Naumann PS, Gessler A, Holst J, Dannenmann M, Mayer H, Kogel-Knabner I, Rennenberg H, Polle A (2010) Girdling affects ectomycorrhizal fungal (EMF) diversity and reveals functional differences in EMF community composition in a beech forest. Appl Environ Microbiol 76:1831-1841. doi:10.1128/AEM.01703-09

Peršoh D (2015) Plant-associated fungal communities in the light of meta'omics. Fungal Divers 75:1-25. doi: 10.1007/s13225-015-0334-9

Philpott TJ, Barker JS, Prescott CE, Grayston SJ (2018) Limited effects of variableretention harvesting on fungal communities decomposing fine roots in coastal temperate rainforests. Appl Environ Microbiol 84:1-16. doi: 10.1128/AEM.02061-17

Porras-Alfaro A, Bayman P (2011) Hidden Fungi , Emergent Properties: Endophytes and Microbiomes. Annu Rev Phytopathol 49:291-315. doi: 10.1146/annurevphyto-080508-081831

R Core Team (2017) R: A language and environment for statistical computing. R Foundation for Statistical Computing, Vienna, Austria. https://www.rproject.org/.

Schopfer P (1989) Experimentelle Pflanzenphysiologie. Spinger DE. 
Schwarz MT, Bischoff S, Blaser S, Boch S, Schmitt B, Thieme L, Fischer M, Michalzik B, Schulze ED, Siemens J, Wilcke W (2014) More efficient aboveground nitrogen use in more diverse Central European forest canopies. For Ecol Manage 313:274-282. doi: 10.1016/j.foreco.2013.11.021

Smith SE, Read DJ (2008) Mycorrhizal symbiosis, 3rd edn. Academic Press, London.

Suz LM, Barsoum N, Benham S, Dietrich H-P, Fetzer KD, Fischer R, García P, Gehrman J, Kristöfel F, Manninger M, Neagu S, Nicolas M, Oldenburger J, Raspe S, Sánchez G, Schröck HW, Schubert A, Verheyen K, Verstraeten A, Bidartondo MI (2014) Environmental drivers of ectomycorrhizal communities in Europe's temperate oak forests. Mol Ecol 23:5628-5644. doi: $10.1111 /$ mec. 12947

Toju H, Tanabe AS, Yamamoto S, Sato H (2012) High-Coverage ITS Primers for the DNA-Based Identification of Ascomycetes and Basidiomycetes in Environmental Samples. PLoS One 7: e40863. doi: 10.1371/journal.pone.0040863

Vannette RL, Leopold DR, Fukami T (2016) Forest area and connectivity influence root-associated fungal communities in a fragmented landscape. Ecol Soc Am 97:2374-2383. doi: 10.1002/ecy.1472

Veach AM, Stokes CE, Knoepp J, Jumpponen A, Baird R (2017) Fungal communities and functional guilds shift along an elevational gradient in the southern Appalachian mountains. Microb Ecol. doi: 10.1007/s00248-017-11166

White TJ, Bruns T, Lee S, Taylor JW (1990) Amplification and direct sequencing of fungal ribosomal RNA genes for phylogenetics. In: A guide to molecular methods and applications (Innis MA, Gelfand DH, Sninsky JJ, White JW, eds). Academic Press, New York, pp 315-322.

de Witte LC, Rosenstock NP, van der Linde S, Braun S (2017) Nitrogen deposition changes ectomycorrhizal communities in Swiss beech forests. Sci Total Environ 605-606:1083-1096. doi: 10.1016/j.scitotenv.2017.06.142

Wubet T, Christ S, Schöning I, Boch S, Gawlich M, Schnabel B, Fischer M, Buscot F (2012) Differences in Soil Fungal Communities between European Beech (Fagus sylvatica L.) Dominated Forests Are Related to Soil and Understory Vegetation. PLoS One 7:e47500. doi: 10.1371/journal.pone.0047500 
Zhang J, Kobert K, Flouri T, Stamatakis A (2014) PEAR: a fast and accurate Illumina Paired-End reAd mergeR. Bioinformatics 30:614-620. doi: 10.1093/bioinformatics/btt593

Zhang Y, Ni J, Tang F, Pei K, Luo Y, Jiang L, Sun L, Liang Y (2016) Rootassociated fungi of Vaccinium carlesii in subtropical forests of China: intra-and inter-annual variability and impacts of human disturbances. Sci Rep 6:22399. doi: 10.1038/srep22399 
CHAPTER 5

CONCLUSION AND OUTLOOK 


\subsection{Conclusion}

This study was carried out to explore environmental drivers and functions of rootassociated fungal communities in relation to $\mathrm{N}$ in temperate forests. Greenhouse and field research approaches were used. A greenhouse experiment was conducted in order to know whether the diversity of EMF and beech provenance affect beech nitrogen and performance. To further understand the role of EMF in beech $\mathrm{N}$ supply at molecular level, root samples from a field beech transplantation experiment were harvested and used to study beech and fungal transcriptomes. To investigate the environmental drivers of RAF, another field approach was undertaken to understand whether the RAF community composition in temperate forests changes among biogeographical regions, and to explore the relationships between the abundance of taxonomic and trophic groups of RAF and nitrogen-related and other important abiotic variables across temperate forests.

Comparing the performance of beech provenances between two soil treatments indicated that the provenances from three biogeographical regions showed no difference in long-term $\mathrm{N}$ nutrition and short-term ${ }^{15} \mathrm{~N}$ uptake. Hainich-Dün provenance performed better in original Hainich-Dün forest soil than SchorfheideChorin and Schwäbische Alb provenances. The result indicates that beech intraspecific diversity has no effects on beech $N$ nutrition and that soil fungal communities, which were adapted locally to Hanich-Dün soil, may play a role in improved performance of Hainich-Dün provenance. Beech plants in original forest soil, which were colonized with higher ectomycorrhizal diversity, showed better performance and improved nitrogen nutrition than those in $\mathrm{Y}$-irradiated soil regardless of tested beech provenance. This finding suggests that EMF may control beech growth and nitrogen supply over two years of experiment (Chapter 2), although the effects of increased EMF diversity on short-term ${ }^{15} \mathrm{~N}$ uptake were not detected. The tested beech provenances exhibited a preference for $\mathrm{NO}_{3}{ }^{-}$over $\mathrm{NH}_{4}{ }^{+}$. Root transcriptome analysis indicates that pattern of transcript abundance of the beech roots samples from Schorfheide-Chorin was different from those from Hainich-Dün and Schwäbische Alb. The majority of differentially expressed genes and enriched gene ontology terms were found between Hainich-Dün and Schorfheide-Chorin. Beech genes (111) and ectomycorrhizal genes (134) were detected to be related to $\mathrm{N}$ uptake and assimilation. Nitrogen-related beech genes were detected to be involved in $\mathrm{NO}_{3}{ }^{-}$transport and assimilation, whereas the fungal genes were found to be related to $\mathrm{NH}_{4}{ }^{+}$assimilation. These results are in line with 
those of chapter 2, suggesting that differences in the molecular regulation of $\mathrm{N}$ uptake lead to segregation of $\mathrm{N}$ utilization und support complementary resource use. The analysis of RAF and their relationships with $\mathrm{N}$-related variables and other environmental variables indicated that biogeographical regions affected the RAF community composition. Stronger effects were observed for the taxonomic fungal community compositions than for the trophic fungal community compositions. Root $\mathrm{NO}_{3}{ }^{-}$and $\mathrm{NH}_{4}{ }^{+}$were drivers for changes in the abundance of trophic fungal community composition, and root $\mathrm{N}$ and $\mathrm{C}$ were more important for the changes in the abundance of the trophic communities than those elements in soil. The results suggest the stronger control of trophic fungal communities by the host trees than soil chemistry. Furthermore, the differences in response pattern of root-associated fungal orders to environmental variables indicate no genetically determined relationships of RAF communities to root and soil $\mathrm{N}$.

Taken key results from the three main chapters into consideration, comparing the $\mathrm{N}$ uptake by beech of the two $\mathrm{N}$ forms indicates that more $\mathrm{NO}_{3}$ - was taken up by beech than $\mathrm{NH}_{4}^{+}$(Chapter 2). A question was whether the higher uptake of $\mathrm{NO}_{3}^{-}$ than $\mathrm{NH}_{4}{ }^{+}$by beech is contributed by beech or EMF or by both beech and EMF. Transcriptome analysis showed that beech genes were involved in $\mathrm{NO}_{3}{ }^{-}$uptake and assimilation whereas fungal genes were related to $\mathrm{NH}_{4}{ }^{+}$assimilation (Chapter 3 ). There were no nitrate transporters were detected in fungal transcriptome (Chapter 3 ). The results suggest that beech might be mainly responsible for $\mathrm{NO}_{3}{ }^{-}$uptake itself, and EMF assist beech in additional $\mathrm{NH}_{4}{ }^{+}$uptake and assimilation. A majority of root-associated fungal orders in our field data analysis were correlated with root $\mathrm{NO}_{3}{ }^{-}$. Among them, root $\mathrm{NO}_{3}{ }^{-}$was negatively related to Agaricales and positively related to Pezizales (Chapter 4). These results support the findings regarding improved beech performance in O soil compared to T soil (Chapter 2). In fact, Tuber rufum, which belongs to Pezizales and was present in $\mathrm{O}$ soil but not in $\mathrm{T}$ soil, might play a role in improved beech performance. The presence of Tuber rufum in $\mathrm{O}$ soil may indirectly improve beech ${ }^{15} \mathrm{NO}_{3}^{-}$uptake by accelerating glutamate metabolism. High abundance of Hebeloma incarnatulum which belongs to Agaricales in T soil may constrain the beech performance because Agaricales was negatively related to root $\mathrm{NO}_{3}{ }^{-}$(Chapter 4). Furthermore, because there was no correlation between root $\mathrm{NO}_{3}{ }^{-}$and Thelephorales, Tomentella sublilacina (belonging to Thelephorales), which occurred in both soil types, may have little contribution to beech performance (Chapter 2). Due to low abundance of Mytilinidiales (8 reads) to which Cenococum geophilum belongs, correlation between Mytilinidiales and abiotic variables were not 
made. Root $\mathrm{NH}_{4}{ }^{+}$was related with fewer root-associated fungal orders and less important than root $\mathrm{NO}_{3}{ }^{-}$(Chapter 4). Overall, $\mathrm{NO}_{3}^{-}$was important for changes in RAF communities, beech nutrition and performance. The results also suggest the important role of specific EMF species in beech $\mathrm{N}$ supply and performance.

\subsection{Outlook}

The improved biomass production was observed for Hanich-Dün beech provenance in $\mathrm{O}$ soil supporting the role of adapted soil microbial communities. However, conclusion regarding effects of local microbial communities on beech growth need to be confirmed by further testing provenances in different soil origins in future studies. Moreover, specific EMF species were suggested to play an important role in beech $\mathrm{N}$ supply; therefore, future research should address taxon-specific $\mathrm{N}$ uptake to understand better beech nitrogen. Because metatranscriptomic approach is a snapshot of the gene expression at a specific time point, temporal root sampling should be required to obtain further understanding about the molecular mechanism of beech-EMF interaction over time. In this study, the present approach was taken based on mixed root samples from multiple plant species in temperate forests. Separation of roots according to plant species should be conducted and used for sequencing to obtain insights into relationships of environmental variables and RAF communities of individual tree species. Furthermore, root sampling for research on RAF community composition and relationships between RAF and abiotic variables was collected at one time point. Seasonal sampling should, therefore, be conducted to obtain knowledge about year-round dynamics of RAF communities. It is also of great interest to explore RAF communities at different soil depths. 
APPENDICES 


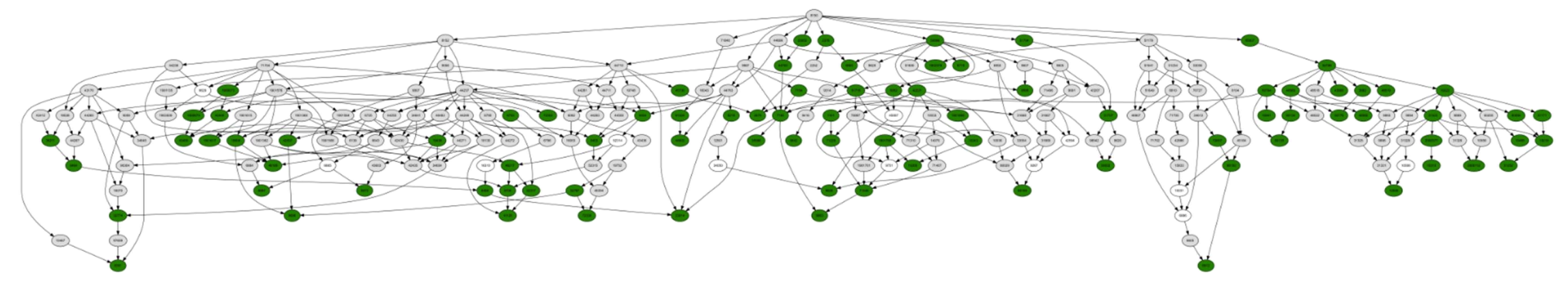

Appendix Fig. 3.1 Hierarchy of enriched GO terms of DEGs between $\mathrm{H}$ and $\mathrm{S}$ regions. Enriched $\mathrm{GO}$ terms were coded green, while white color indicate GO terms which were not enriched. 


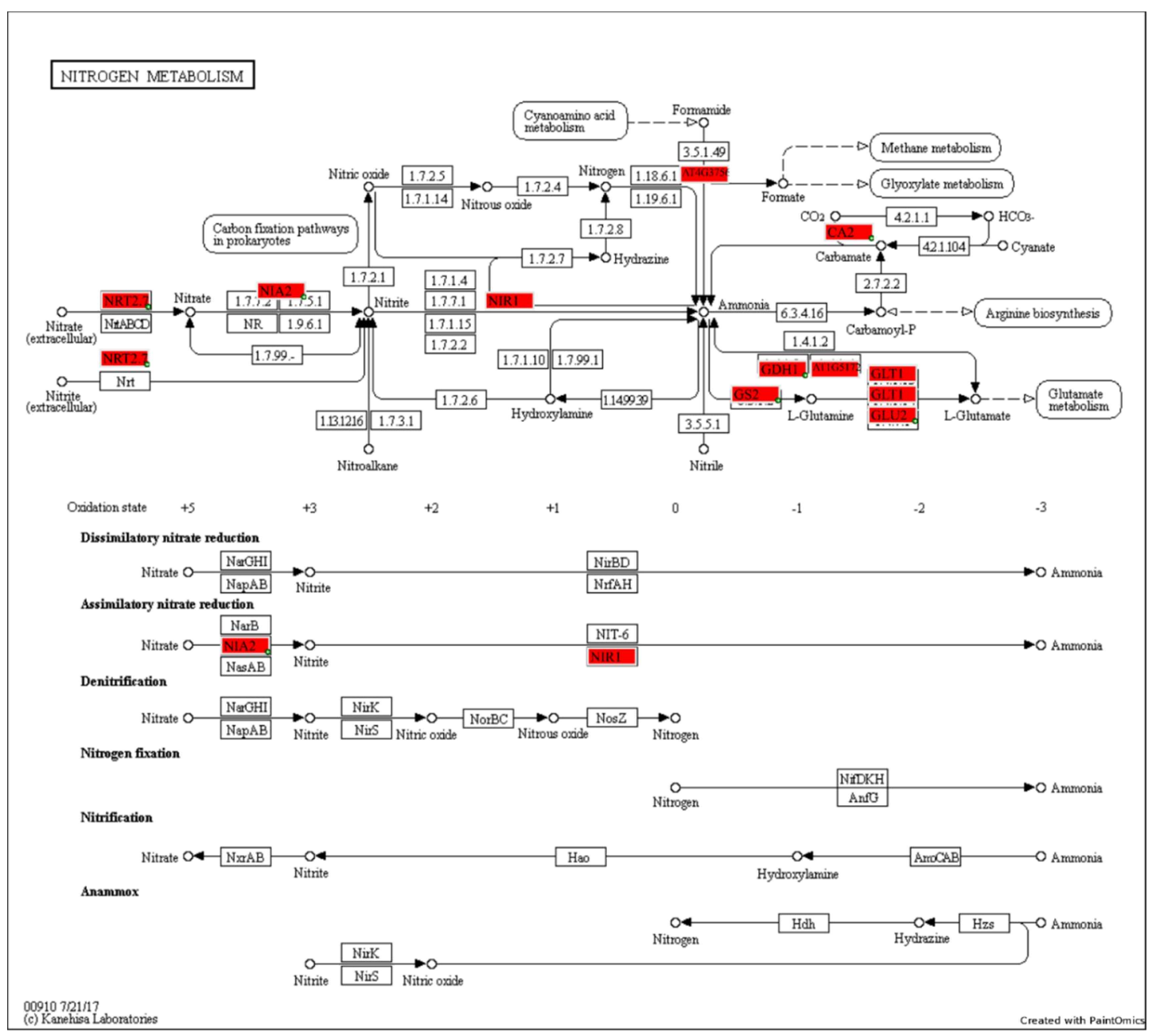

Appendix Fig. 3.2 Nitrogen metabolism of beech. Red colours indicate beech genes involved in nitrogen metabolism. The result was obtained from Paintomics 3 using list of genes from the beech transcriptome database in GenBank (ID number HADB00000000.1) according to AGI ID as input data. 


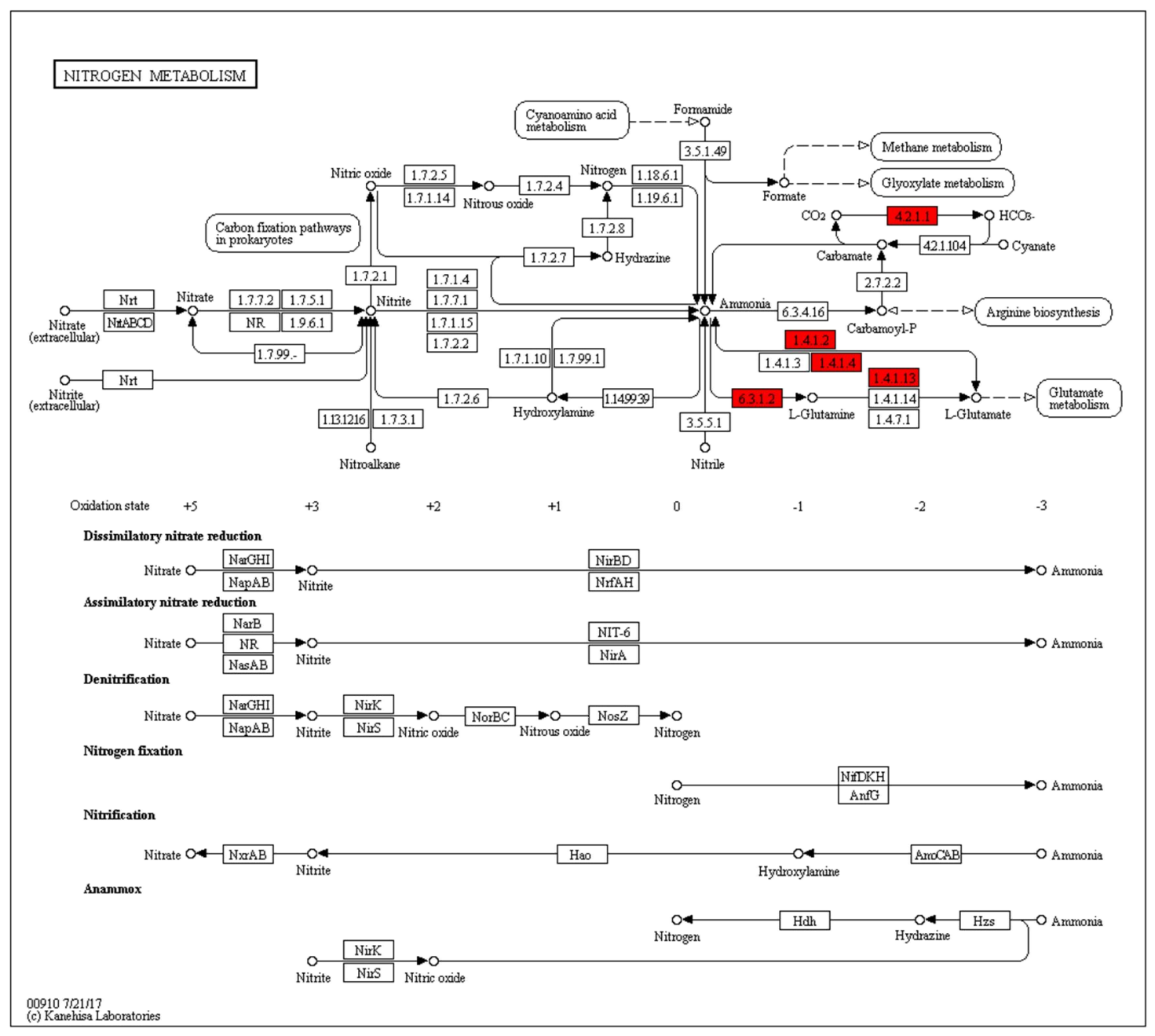

Appendix Fig. 3.3 Nitrogen metabolism of Laccaria bicolor. Red colour indicates fungal genes involved in nitrogen metabolism. The result was obtained from KEGG mapper-Search\&Color Pathway using EC number from the fungal transcriptome as input data 
Appendix Table 3.1 Field experimental plots where beech nuts were collected, the seedlings were planted out, harvested and used for RNA Seq

\begin{tabular}{|c|c|c|c|c|c|}
\hline $\begin{array}{l}\text { Study } \\
\text { region }\end{array}$ & Plot & Collection plot & Planting plot & $\begin{array}{l}\text { Harvest } \\
\text { plot }\end{array}$ & Plot for RNA Seq \\
\hline Schwäbische & 5 & $x$ & $\mathrm{x}$ & $\mathrm{x}$ & $x$ \\
\hline \multirow{9}{*}{ Alb } & 6 & & $x$ & $x$ & $x$ \\
\hline & 7 & $\mathrm{x}$ & $\mathrm{x}$ & & \\
\hline & 8 & $x$ & & & \\
\hline & 9 & $\mathrm{x}$ & $\mathrm{x}$ & & \\
\hline & 29 & & $\mathrm{x}$ & $\mathrm{x}$ & \\
\hline & 39 & & $x$ & $x$ & $\mathrm{x}$ \\
\hline & 41 & & $\mathrm{x}$ & & \\
\hline & 42 & & $\mathrm{x}$ & $\mathrm{x}$ & $x$ \\
\hline & 50 & & $\mathrm{x}$ & & \\
\hline \multirow[t]{12}{*}{ Hainich-Dün } & 5 & & $x$ & $x$ & $x$ \\
\hline & 6 & $\mathrm{x}$ & & & \\
\hline & 8 & & $\mathrm{x}$ & & \\
\hline & 10 & $x$ & & & \\
\hline & 11 & $x$ & $\mathrm{x}$ & & \\
\hline & 12 & $\mathrm{x}$ & $\mathrm{x}$ & $x$ & $\mathrm{x}$ \\
\hline & 16 & & $\mathrm{x}$ & $\mathrm{x}$ & $\mathrm{x}$ \\
\hline & 21 & & $\mathrm{x}$ & $\mathrm{x}$ & $x$ \\
\hline & 26 & & $\mathrm{x}$ & & \\
\hline & 27 & & $\mathrm{x}$ & & \\
\hline & 29 & & & & \\
\hline & 35 & & $\mathrm{x}$ & & \\
\hline Schorfheide- & 5 & $\mathrm{x}$ & $x$ & & \\
\hline \multirow[t]{9}{*}{ Chorin } & 6 & $\mathrm{x}$ & & & \\
\hline & 9 & $x$ & $\mathrm{x}$ & & \\
\hline & 31 & & $\mathrm{x}$ & & \\
\hline & 34 & & $\mathrm{x}$ & $x$ & $\mathrm{x}$ \\
\hline & 35 & & $x$ & $x$ & $x$ \\
\hline & 37 & & $\mathrm{x}$ & $x$ & $x$ \\
\hline & 38 & & $\mathrm{x}$ & $\mathrm{x}$ & $\mathrm{x}$ \\
\hline & 46 & $x$ & $\mathrm{x}$ & & \\
\hline & 49 & & $\mathrm{x}$ & $\mathrm{x}$ & \\
\hline
\end{tabular}


Appendix Table 3.2 A list of ectomycorrjizal fungi which is associated with beech and commonly observed in temperate forests for mapping fungal transcriptomic data

\begin{tabular}{llll}
\hline & Ectomycorrhiza & Abbreviation & Information contributor* \\
\hline 1 & Boletus edulis & Boled & Andrea Polle \\
2 & Paxillus involutus & Paxin & Andrea Polle \\
3 & Rhizopogon vinicolor & Rhivi & Andrea Polle \\
4 & Scleroderma citrinum & Sclci & Andrea Polle \\
5 & Suillus brevipes & Suibr & Andrea Polle \\
6 & Suillus luteus & Suilu & Andrea Polle \\
7 & Amanita muscaria & Amamu & Kristina Schröter \\
8 & Clavulina sp & ClaPMl390 & Kristina Schröter \\
9 & Laccaria amethystina & Lacam & Kristina Schröter \\
10 & Laccaria bicolor & Lacbi & Kristina Schröter \\
11 & Lactifluus volemus & Lacvol & Kristina Schröter \\
12 & Russula brevipes & Rusbre & Kristina Schröter \\
13 & Russula dissimulans & Rusdis & Kristina Schröter \\
14 & Russula rugulosa & Rusrug & Kristina Schröter \\
15 & Sebacina vermifera & Sebve & Kristina Schröter \\
16 & Acephala macrosclerotiorum & Acema & Silke Ammerschubert \\
17 & Cenococcum geophilum & Cenge & Silke Ammerschubert \\
18 & Hebeloma cylindrosporum & Hebcy & Silke Ammerschubert \\
19 & Hymenoscyphus varicosporoides & Hymva & Silke Ammerschubert \\
20 & Lactarius quietus & Lacqui & Silke Ammerschubert \\
21 & Mortierella elongata & Morel & Silke Ammerschubert \\
22 & Phialocephala scopiformis & Phisc & Silke Ammerschubert \\
23 & Piloderma croceum & Pilcr & Silke Ammerschubert \\
24 & Tricholoma matsutake & Trima & Silke Ammerschubert \\
25 & Tuber borchii & Tubbor & Silke Ammerschubert \\
26 & Wilcoxina mikolae & Wilmi & Silke Ammerschubert \\
27 & Xerocomus badius & Xerba & Silke Ammerschubert \\
\hline
\end{tabular}

* The person who contributed information about fungal species which are associated with beech in 150 forest plots in the Biodiversity Exploraories 
Appendix Table 3.3 N-related beech "genes" which belong to GO:0010243 and GO:0051171

GO:0010243 (64 genes)

fasyl 0039072, fasyl 0209646, fasyl 0315645, fasyl 0335115, fasyl 0405009 , fasyl 0506550, fasyl 0654202, fasyl 0656465, fasyl 0696282, fasyl 0750520, fasyl 0905213, fasyl 0952951, fasyl 0972042, fasyl 0975780, fasyl 0981716, fasyl 1191726, fasyl 1227766, fasyl 1261849, fasyl 1387574, fasyl 1529761, fasyl 1566326, fasyl 1602866, fasyl 1604473, fasyl 1740886, fasyl 1795448, fasyl 1812836, fasyl 1814668, fasyl 1818317, fasyl 1847386, fasyl 1883823, fasyl 1886503, fasyl 1950264, fasyl 1965879, fasyl 1968305, fasyl 2025207, fasyl 2084470, fasyl 2167877, fasyl 2192216, fasyl 2294623, fasyl 2400233, fasyl 2440069, fasyl 2458112, fasyl 2482184, fasyl 2494511, fasyl 2508042, fasyl 2521052, fasyl 2530495, fasyl 2558898, fasyl 2561234, fasyl 2561287, fasyl 2561852, fasyl 2562295, fasyl 2564152, fasyl 2564585, fasyl 2567425, fasyl 2568542, fasyl 2568910, fasyl 2569308, fasyl 2569882, fasyl 2569888, fasyl 2570184, fasyl 2571491, fasyl 2572571, fasyl 2572860

GO: 0051171 (65 genes)

fasyl 0000917, fasyl 0039072, fasyl 0056283, fasyl 0133768, fasyl 0209646, fasyl 0269187, fasyl 0315645, fasyl 0387823, fasyl 0471418, fasyl 0531870, fasyl 0546407, fasyl 0551049, fasyl 0592673, fasyl 0632798, fasyl 0654202, fasyl 0656465, fasyl 0696282, fasyl 0750520, fasyl 0881101, fasyl 0973606, fasyl 0979330, fasyl 1218425, fasyl 1227766, fasyl 1397641, fasyl 1470509, fasyl 1522087, fasyl 1529761, fasyl 1559642, fasyl 1686239, fasyl 1693434, fasyl 1731194, fasyl 1780685, fasyl 1795448, fasyl 1812198, fasyl 1812836, fasyl 1816289, fasyl 1818317, fasyl 1856028, fasyl 1867532, fasyl 1895060 , fasyl 2004906, fasyl 2117386, fasyl 2137253, fasyl 2192216, fasyl 2294623, fasyl 2375059, fasyl 2428951, fasyl 2440069, fasyl 2458112, fasyl 2482184, fasyl 2500953, fasyl 2508042, fasyl 2558274, fasyl 2558898, fasyl 2561852, fasyl 2562745, fasyl 2564152, fasyl 2564836, fasyl 2567425, fasyl 2567951, fasyl 2569308, fasyl 2569888, fasyl 2569927, fasyl 2570184, fasyl 2572571 
Appendix Table $3.4 \mathrm{~N}$-related genes in the beech transcriptome. These genes obtained from mapping the transcriptome against $\mathrm{N}$ metabolism and from doing keyword search for nitrate and ammonium transporters using the beech transcriptome. Fasyl: Fagus sylvatica, $\mathrm{H}$ : Hainich Dün; S: Schorfheide-Chorin, A: Schwäbische Alb, Yellow colour: genes involved in N metabolism, Log2fc: log2 fold change

\begin{tabular}{|c|c|c|c|c|c|c|c|c|c|c|}
\hline & \multirow{2}{*}{ Fasyl ID } & \multirow{2}{*}{ Gene name } & \multirow{2}{*}{ AGI ID } & \multicolumn{2}{|c|}{$\mathrm{H}-\mathrm{S}$} & \multicolumn{2}{|c|}{$\mathrm{H}-\mathrm{A}$} & \multicolumn{2}{|c|}{ S-A } & \multirow[t]{2}{*}{ Function } \\
\hline & & & & Log2fc & $p$ value & Log2fc & $p$ value & Log2fc & $p$ value & \\
\hline 1 & fasyl_1621113 & ACA1 & AT3G52720 & -0.817 & 1.000 & -0.745 & 1.000 & 0.073 & 1.000 & alpha carbonic anhydrase 1 \\
\hline 2 & fasyl_2250854 & ACA4 & AT4G20990 & -0.237 & 1.000 & -0.183 & 1.000 & 0.054 & 1.000 & alpha carbonic anhydrase 4 \\
\hline 3 & fasyl_1776839 & ACA7 & AT1G08080 & -0.284 & 1.000 & -0.446 & 1.000 & -0.161 & 1.000 & alpha carbonic anhydrase 7 \\
\hline 4 & fasyl_0593659 & ACA7 & AT1G08080 & 0.032 & 0.983 & 0.519 & 1.000 & 0.487 & 0.678 & alpha carbonic anhydrase 7 \\
\hline 5 & fasyl_0569751 & ACA7 & AT1G08080 & -0.351 & 0.789 & 0.096 & 1.000 & 0.448 & 0.781 & alpha carbonic anhydrase 7 \\
\hline 6 & fasyl_2569622 & AT1G51720 & AT1G51720 & -0.003 & 0.998 & -0.117 & 1.000 & -0.115 & 0.912 & Amino acid dehydrogenase family protein \\
\hline 7 & fasyl_2566762 & AT1G51720 & AT1G51720 & 0.261 & 0.771 & 0.134 & 1.000 & -0.127 & 0.935 & Amino acid dehydrogenase family protein \\
\hline 8 & fasyl_1774376 & AT1G51720 & AT1G51720 & 0.025 & 0.981 & 0.339 & 1.000 & 0.314 & 0.698 & Amino acid dehydrogenase family protein \\
\hline 9 & fasyl_1271906 & AT1G51720 & AT1G51720 & 0.156 & 1.000 & -0.376 & 1.000 & -0.532 & 1.000 & Amino acid dehydrogenase family protein \\
\hline 10 & fasyl_0129825 & AT1G51720 & AT1G51720 & -0.590 & 1.000 & 0.181 & 1.000 & 0.771 & 1.000 & Amino acid dehydrogenase family protein \\
\hline 11 & fasyl_1015882 & AT1G51720 & AT1G51720 & 0.021 & 1.000 & 0.245 & 1.000 & 0.223 & 1.000 & Amino acid dehydrogenase family protein \\
\hline 12 & fasyl_2224379 & AT4G37560 & AT4G37560 & 0.171 & 0.897 & -0.222 & 1.000 & -0.393 & 0.769 & Acetamidase/Formamidase family protein \\
\hline 13 & fasyl 1685580 & AT4G37560 & AT4G37560 & 0.131 & 0.937 & -0.027 & 1.000 & -0.158 & 0.940 & Acetamidase/Formamidase family protein \\
\hline 14 & fasyl_0614143 & AT4G37560 & AT4G37560 & 0.060 & 0.968 & -0.149 & 1.000 & -0.210 & 0.889 & Acetamidase/Formamidase family protein \\
\hline 15 & fasyl_1320821 & BCA5 & AT4G33580 & 0.058 & 1.000 & -0.139 & 1.000 & -0.196 & 1.000 & beta carbonic anhydrase 5 \\
\hline 16 & fasyl_0239657 & BCA5 & AT4G33580 & -0.495 & 0.612 & -0.509 & 1.000 & -0.015 & 0.994 & beta carbonic anhydrase 5 \\
\hline 17 & fasyl_2155958 & BCA5 & AT4G33580 & -0.638 & 0.410 & -0.409 & 1.000 & 0.229 & 0.890 & beta carbonic anhydrase 5 \\
\hline 18 & fasyl_2558280 & BCA5 & AT4G33580 & 0.540 & 0.480 & 0.368 & 1.000 & -0.172 & 0.917 & beta carbonic anhydrase 5 \\
\hline 19 & fasyl_0028039 & BCA5 & AT4G33580 & 0.738 & 0.345 & 0.606 & 1.000 & -0.132 & 1.000 & beta carbonic anhydrase 5 \\
\hline 20 & fasyl_1394408 & CA1 & AT3G01500 & -0.812 & 1.000 & -0.558 & 1.000 & 0.254 & 1.000 & carbonic anhydrase 1 \\
\hline 21 & fasyl_1886503 & CA2 & AT5G14740 & -0.804 & 0.037 & -0.364 & 1.000 & 0.440 & 0.579 & carbonic anhydrase 2 \\
\hline 22 & fasyl_2568912 & CA2 & AT5G14740 & -0.128 & 0.933 & 0.405 & 1.000 & 0.533 & 0.656 & carbonic anhydrase 2 \\
\hline 23 & fasyl_0144715 & CA2 & AT5G14740 & -0.083 & 0.961 & 0.476 & 1.000 & 0.559 & 0.648 & carbonic anhydrase 2 \\
\hline 24 & fasyl_0138595 & CA2 & AT5G14740 & -0.720 & 0.164 & -0.332 & 1.000 & 0.387 & 0.709 & carbonic anhydrase 2 \\
\hline 25 & fasyl_0119002 & CA2 & AT5G14740 & 0.272 & 0.811 & 0.599 & 1.000 & 0.327 & 0.821 & carbonic anhydrase 2 \\
\hline 26 & fasyl_2430631 & GDH1 & AT5G18170 & -0.064 & 0.961 & -0.134 & 1.000 & -0.071 & 0.968 & glutamate dehydrogenase 1 \\
\hline 27 & fasyl_2279097 & GDH1 & AT5G18170 & 0.030 & 1.000 & 0.191 & 1.000 & 0.161 & 1.000 & glutamate dehydrogenase 1 \\
\hline 28 & fasyl_1182924 & GDH1 & AT5G18170 & 0.189 & 1.000 & 0.696 & 1.000 & 0.506 & 1.000 & glutamate dehydrogenase 1 \\
\hline 29 & fasyl_2559332 & GDH1 & AT5G18170 & -0.322 & 0.735 & -0.223 & 1.000 & 0.099 & 0.956 & glutamate dehydrogenase 1 \\
\hline
\end{tabular}




\begin{tabular}{|c|c|c|c|c|c|c|c|c|c|c|}
\hline 30 & fasyl_2028990 & GDH1 & AT5G18170 & -0.456 & 0.528 & -0.045 & 1.000 & 0.410 & 0.691 & glutamate dehydrogenase 1 \\
\hline 31 & fasyl_0450109 & GDH2 & AT5G07440 & 0.391 & 1.000 & 0.099 & 1.000 & -0.292 & 1.000 & glutamate dehydrogenase 2 \\
\hline 32 & fasyl_1384250 & GDH2 & AT5G07440 & 1.181 & 0.032 & 0.516 & 1.000 & -0.665 & 0.562 & glutamate dehydrogenase 2 \\
\hline 33 & fasyl_2567469 & $\mathrm{GDH} 2$ & AT5G07440 & 0.309 & 0.778 & 0.425 & 1.000 & 0.117 & 0.952 & glutamate dehydrogenase 2 \\
\hline 34 & fasyl_2308625 & GDH2 & AT5G07440 & 0.879 & 0.204 & 0.258 & 1.000 & -0.622 & 0.610 & glutamate dehydrogenase 2 \\
\hline 35 & fasyl_0284218 & GDH2 & AT5G07440 & 0.334 & 0.755 & 0.554 & 1.000 & 0.220 & 0.894 & glutamate dehydrogenase 2 \\
\hline 36 & fasyl_2115554 & GDH2 & AT5G07440 & 1.277 & 0.011 & 0.569 & 1.000 & -0.708 & 0.493 & glutamate dehydrogenase 2 \\
\hline 37 & fasyl_1488290 & GDH2 & AT5G07440 & 0.832 & 0.234 & 0.437 & 1.000 & -0.394 & 0.793 & glutamate dehydrogenase 2 \\
\hline 38 & fasyl_0976755 & GDH2 & AT5G07440 & -0.029 & 0.988 & 0.236 & 1.000 & 0.265 & 1.000 & glutamate dehydrogenase 2 \\
\hline 39 & fasyl_0391853 & GLN1.3 & AT3G17820 & 0.143 & 1.000 & 0.295 & 1.000 & 0.152 & 1.000 & glutamine synthetase 1.3 \\
\hline 40 & fasyl_1319886 & GLT1 & AT5G53460 & -0.323 & 1.000 & -0.173 & 1.000 & 0.151 & 1.000 & NADH-dependent glutamate synthase 1 \\
\hline 41 & fasyl_2291512 & GLT1 & AT5G53460 & -0.453 & 1.000 & -0.221 & 1.000 & 0.232 & 1.000 & NADH-dependent glutamate synthase 1 \\
\hline 42 & fasyl_0792729 & GLT1 & AT5G53460 & -0.489 & 0.429 & -0.174 & 1.000 & 0.314 & 0.774 & $\mathrm{NADH}$-dependent glutamate synthase 1 \\
\hline 43 & fasyl_1680520 & GLT1 & AT5G53460 & -0.406 & 0.621 & -0.502 & 1.000 & -0.096 & 0.956 & $\mathrm{NADH}$-dependent glutamate synthase 1 \\
\hline 44 & fasyl_1169052 & GLT1 & AT5G53460 & 0.211 & 1.000 & 0.012 & 1.000 & -0.200 & 1.000 & $\mathrm{NADH}$-dependent glutamate synthase 1 \\
\hline 45 & fasyl_0160678 & GLT1 & AT5G53460 & -0.539 & 0.384 & -0.204 & 1.000 & 0.335 & 0.763 & NADH-dependent glutamate synthase 1 \\
\hline 46 & fasyl_1058148 & GLT1 & AT5G53460 & -0.278 & 1.000 & -0.358 & 1.000 & -0.080 & 1.000 & $\mathrm{NADH}$-dependent glutamate synthase 1 \\
\hline 47 & fasyl_0076001 & GLT1 & AT5G53460 & -0.688 & 0.150 & -0.215 & 1.000 & 0.473 & 0.585 & $\mathrm{NADH}$-dependent glutamate synthase 1 \\
\hline 48 & fasyl_0076000 & GLT1 & AT5G53460 & -0.488 & 1.000 & -0.159 & 1.000 & 0.328 & 1.000 & $\mathrm{NADH}$-dependent glutamate synthase 1 \\
\hline 49 & fasyl_1897902 & GLU1 & AT5G04140 & -0.082 & 0.963 & 0.091 & 1.000 & 0.173 & 1.000 & glutamate synthase 1 \\
\hline 50 & fasyl_2567974 & GLU1 & AT5G04140 & 0.078 & 0.953 & -0.096 & 1.000 & -0.174 & 0.901 & glutamate synthase 1 \\
\hline 51 & fasyl_2567363 & GLU1 & AT5G04140 & 0.188 & 0.868 & -0.050 & 1.000 & -0.239 & 0.863 & glutamate synthase 1 \\
\hline 52 & fasyl_1169208 & GLU1 & AT5G04140 & -0.060 & 0.958 & -0.166 & 1.000 & -0.106 & 0.936 & glutamate synthase 1 \\
\hline 53 & fasyl_1622159 & GLU1 & AT5G04140 & -0.004 & 0.998 & -0.256 & 1.000 & -0.251 & 0.826 & glutamate synthase 1 \\
\hline 54 & fasyl_1460472 & GLU1 & AT5G04140 & 0.018 & 0.987 & -0.119 & 1.000 & -0.137 & 0.905 & glutamate synthase 1 \\
\hline 55 & fasyl_0603322 & GLU2 & AT2G41220 & 0.041 & 0.979 & -0.049 & 1.000 & -0.089 & 0.962 & glutamate synthase 2 \\
\hline 56 & fasyl_0700968 & GS2 & AT5G35630 & -0.486 & 1.000 & 0.166 & 1.000 & 0.652 & 1.000 & glutamine synthetase 2 \\
\hline 57 & fasyl_0170119 & GS2 & AT5G35630 & -0.206 & 1.000 & 0.035 & 1.000 & 0.241 & 1.000 & glutamine synthetase 2 \\
\hline 58 & fasyl_0952505 & GSR_1 & AT5G37600 & 0.207 & 0.851 & -0.081 & 1.000 & -0.287 & 0.825 & glutamine synthase clone R1 \\
\hline 59 & fasyl_2340284 & GSR_1 & AT5G37600 & -0.194 & 1.000 & 0.076 & 1.000 & 0.270 & 1.000 & glutamine synthase clone R1 \\
\hline 60 & fasyl_1832704 & GSR_1 & AT5G37600 & -0.461 & 0.639 & 0.100 & 1.000 & 0.561 & 0.645 & glutamine synthase clone R1 \\
\hline 61 & fasyl_1163541 & GSR_1 & AT5G37600 & 0.538 & 1.000 & 0.170 & 1.000 & -0.369 & 1.000 & glutamine synthase clone R1 \\
\hline 62 & fasyl_1114376 & GSR_1 & AT5G37600 & 0.298 & 1.000 & 0.303 & 1.000 & 0.000 & 1.000 & glutamine synthase clone R1 \\
\hline 63 & fasyl_0614595 & GSR_1 & AT5G37600 & 0.109 & 1.000 & -0.239 & 1.000 & -0.348 & 1.000 & glutamine synthase clone R1 \\
\hline 64 & fasyl_2546236 & GSR_1 & AT5G37600 & -0.925 & 1.000 & -0.119 & 1.000 & 0.807 & 1.000 & glutamine synthase clone R1 \\
\hline 65 & fasyl_0609862 & NIA1 & AT1G77760 & -0.229 & 0.885 & 0.093 & 1.000 & 0.321 & 0.864 & nitrate reductase 1 \\
\hline 66 & fasyl_2169193 & NIA2 & AT1G37130 & -0.480 & 0.680 & 0.219 & 1.000 & 0.699 & 0.589 & nitrate reductase 2 \\
\hline 67 & fasyl_1594841 & NIA2 & AT1G37130 & -0.358 & 0.793 & 0.258 & 1.000 & 0.616 & 0.664 & nitrate reductase 2 \\
\hline 68 & fasyl_0948436 & NIR1 & AT2G15620 & 0.335 & 0.790 & 0.459 & 1.000 & 0.124 & 0.955 & nitrite reductase 1 \\
\hline
\end{tabular}




\begin{tabular}{|c|c|c|c|c|c|c|c|c|c|}
\hline 69 & fasyl_0829064 & NIR1 & AT2G15620 & -0.100 & 1.000 & -0.005 & 1.000 & 0.095 & 1.000 \\
\hline 70 & fasyl_0819600 & NIR1 & AT2G15620 & 0.275 & 0.856 & 0.276 & 1.000 & 0.001 & 1.000 \\
\hline 71 & fasyl_0075946 & NIR1 & AT2G15620 & 0.560 & 0.640 & 0.385 & 1.000 & -0.175 & 1.0 \\
\hline 72 & fasyl_0845329 & NRT2.5 & AT1G12940 & 0.467 & 1.000 & 0.354 & 1.000 & -0.113 & 1.0 \\
\hline 73 & fasyl_0321329 & NRT2.5 & AT1G12940 & 0.260 & 1.000 & 0.133 & 1.000 & -0.127 & 1.0 \\
\hline 74 & fasyl_0688632 & NRT2.5 & AT1G12940 & 0.273 & 0.829 & 0.402 & 1.000 & 0.129 & 0.9 \\
\hline 75 & fasyl_0554271 & NRT2.5 & AT1G12940 & 0.330 & 1.000 & -0.253 & 1.000 & -0.583 & 1.0 \\
\hline 76 & fasyl_2449251 & NRT2.5 & AT1G12940 & 0.413 & 0.699 & 0.365 & 1.000 & -0.048 & \\
\hline 77 & fasyl_1283739 & NRT2.7 & AT5G14570 & 1.175 & 1.000 & 0.447 & 1.000 & -0.728 & \\
\hline 78 & fasyl_2528693 & NRT2.7 & AT5G14570 & -0.831 & 1.000 & 0.215 & 1.000 & 1.046 & \\
\hline 79 & fasyl_0036908 & NRT2.7 & AT5G14570 & 0.104 & 1.000 & 0.379 & 1.000 & 0.275 & \\
\hline 80 & fasyl_0027662 & NRT2.7 & AT5G14570 & 0.263 & 1.000 & 0.607 & 1.000 & 0.344 & 1.0 \\
\hline 81 & fasyl_0092364 & NRT1.1 & AT1G12110 & -0.104 & 0.952 & -0.200 & 1.000 & -0.096 & 0.9 \\
\hline 82 & fasyl_2558839 & NRT1.1 & AT1G12110 & -0.235 & 0.864 & -0.131 & 1.000 & 0.104 & 0.9 \\
\hline 83 & fasyl_0078523 & NRT1.5 & AT1G32450 & 0.997 & 1.000 & 0.800 & 1.000 & -0.197 & 1.0 \\
\hline 84 & fasyl_0117415 & NRT1.5 & AT1G32450 & -0.291 & 0.852 & -0.627 & 1.000 & -0.335 & 0.8 \\
\hline 85 & fasyl_0760882 & NRT1.5 & AT1G32450 & -0.351 & 0.807 & -0.517 & 1.000 & -0.166 & 0.9 \\
\hline 86 & fasyl_1458839 & NRT1.5 & AT1G32450 & -0.345 & 0.812 & -0.476 & 1.000 & -0.131 & 0.9 \\
\hline 87 & fasyl_1463770 & NRT1.5 & AT1G32450 & 0.353 & 1.000 & 0.688 & 1.000 & 0.335 & 1.0 \\
\hline 88 & fasyl_2418771 & NRT1.5 & AT1G32450 & -0.884 & 1.000 & 0.005 & 1.000 & 0.889 & 1.0 \\
\hline 89 & fasyl_2564957 & NRT1.5 & AT1G32450 & 1.423 & 0.029 & 1.096 & 1.000 & -0.327 & 0.8 \\
\hline 90 & fasyl_0224199 & NRT1.7 & AT1G69870 & -0.861 & 1.000 & -0.300 & 1.000 & 0.562 & 1.0 \\
\hline 91 & fasyl_2042055 & NRT1.7 & AT1G69870 & -1.051 & 1.000 & 0.208 & 1.000 & 1.259 & 1.0 \\
\hline 92 & fasyl_2273703 & NRT1.7 & AT1G69870 & -0.842 & 1.000 & -0.061 & 1.000 & 0.780 & 1.0 \\
\hline 93 & fasyl_2568183 & NRT1.7 & AT1G69870 & -1.449 & 0.003 & 0.376 & 1.000 & 1.826 & 0.0 \\
\hline 94 & fasyl_0281961 & NRT1:2 & AT1G69850 & 0.570 & 1.000 & 0.383 & 1.000 & -0.186 & 1.00 \\
\hline 95 & fasyl_0662237 & NRT1:2 & AT1G69850 & -0.264 & 0.844 & 0.129 & 1.000 & 0.393 & 1.0 \\
\hline 96 & fasyl_1230789 & NRT1:2 & AT1G69850 & -0.021 & 0.991 & -0.483 & 1.000 & -0.462 & 1.0 \\
\hline 97 & fasyl_1235428 & NRT1:2 & AT1G69850 & -0.117 & 1.000 & 0.050 & 1.000 & 0.167 & 1.0 \\
\hline 98 & fasyl_1316850 & NRT1:2 & AT1G69850 & 0.104 & 0.945 & 0.118 & 1.000 & 0.014 & 0.9 \\
\hline 99 & fasyl_1342999 & NRT1:2 & AT1G69850 & -0.153 & 0.896 & -0.456 & 1.000 & -0.303 & 0.8 \\
\hline 100 & fasyl_2125755 & NRT1:2 & AT1G69850 & -0.797 & 1.000 & -0.027 & 1.000 & 0.770 & 1.0 \\
\hline 101 & fasyl_2558101 & NRT1:2 & AT1G69850 & -0.367 & 1.000 & -0.145 & 1.000 & 0.222 & 1.0 \\
\hline 102 & fasyl_0129718 & AMT1;1 & AT4G13510 & 0.263 & 0.856 & 0.290 & 1.000 & 0.027 & 1.0 \\
\hline 103 & fasyl_0375136 & AMT1;1 & AT4G13510 & -0.249 & 1.000 & -0.185 & 1.000 & 0.064 & 1.0 \\
\hline 104 & fasyl_1065322 & AMT1;1 & AT4G13510 & -0.132 & 1.000 & -0.744 & 1.000 & -0.612 & 1.00 \\
\hline 105 & asyl_1834562 & AMT1;1 & AT4G13510 & 0.036 & 1.000 & -0.250 & 1.000 & -0.286 & 1.00 \\
\hline 106 & ssyl_2569115 & AMT1;1 & AT4G13510 & -0.263 & 0.698 & -0.228 & 1.000 & 0.035 & $0.9 \varepsilon$ \\
\hline 107 & fasyl_0341208 & AMT2 & AT2G38290 & -0.338 & 0.704 & -0.481 & 1.000 & -0.143 & 0.9 \\
\hline
\end{tabular}

nitrite reductase 1

nitrite reductase 1

nitrite reductase 1

nitrate transporter2.5

nitrate transporter 2.5

nitrate transporter 2.5

nitrate transporter 2.5

nitrate transporter2.5

high affinity nitrate transporter 2.7

high affinity nitrate transporter 2.7

high affinity nitrate transporter 2.7

high affinity nitrate transporter 2.7

nitrate transporter 1.1

nitrate transporter 1.1

nitrate transporter 1.5

nitrate transporter 1.5

nitrate transporter 1.5

nitrate transporter 1.5

nitrate transporter 1.5

nitrate transporter 1.5

nitrate transporter 1.5

nitrate transporter 1.7

nitrate transporter 1.7

nitrate transporter 1.7

nitrate transporter 1.7

nitrate transporter $1: 2$

nitrate transporter 1:2

nitrate transporter 1:2

nitrate transporter $1: 2$

nitrate transporter $1: 2$

nitrate transporter 1:2

nitrate transporter $1: 2$

ammonium transporter $1 ; 1$

ammonium transporter 1;1

ammonium transporter $1 ; 1$

ammonium transporter $1 ;$

ammonium transporter $1 ; 1$

ammonium transporter 2 
108 fasyl_1489616

109 fasyl_1594973

AMT2

AT2G38290

AMT2

0.333

1.000

$0.102 \quad 1.000$

fasyl_1678058

AMT2

AT2G38290

0.413

0.723

0.304

1.000

$-0.231$

$0.036 \quad 0.978$

$-0.099 \quad 1.000$

$-0.044$

1.000

111 fasyl 2239635

AMT2 AT2G38290 0.036

$-0.135 \quad 0.918$

ammonium transporter 2

ammonium transporter 2

ammonium transporter 2

ammonium transporter 2 
Appendix Table 3.5 N-related genes in the fungal transcriptome. These genes obtained from mapping the fungal transcriptome against $\mathrm{N}$ metabolism and from doing keyword search for nitrate and ammonium transporters using the fungal transcriptome. Yellow colour: genes involved in $\mathrm{N}$ metabolism, KOG: Eucaryotic Orthologous Groups, EC number: Enzyme Commission number.

\begin{tabular}{|c|c|c|c|c|c|}
\hline & Fungal ID & $\begin{array}{l}\text { Fungal } \\
\text { species* }\end{array}$ & KOG ID & $\begin{array}{l}\text { EC } \\
\text { number }\end{array}$ & Function \\
\hline 1 & Acema1.173726 & Acema & KOG1578 & 4.2 .1 .1 & Carbonate dehydratase \\
\hline 2 & Acema1.252825 & Acema & KOG0382 & 4.2.1.1 & Carbonate dehydratase \\
\hline 3 & Acema1.42563 & Acema & KOG0382 & 4.2.1.1 & Carbonate dehydratase \\
\hline 4 & Acema1.563058 & Acema & KOG1578 & 4.2.1.1 & Carbonate dehydratase \\
\hline 5 & Acema1.602334 & Acema & KOG1578 & 4.2.1.1 & Carbonate dehydratase \\
\hline 6 & Amamu1.184360 & Amamu & KOG1578 & 4.2.1.1 & Carbonate dehydratase \\
\hline 7 & Amamu1.187012 & Amamu & KOG1578 & 4.2.1.1 & Carbonate dehydratase \\
\hline 8 & Boled1.945473 & Boled & KOG1578 & 4.2.1.1 & Carbonate dehydratase \\
\hline 9 & Boled1.959507 & Boled & KOG1578 & 4.2.1.1 & Carbonate dehydratase \\
\hline 10 & Cenge3.532183 & Cenge & KOG0382 & 4.2.1.1 & Carbonate dehydratase \\
\hline 11 & Cenge3.658527 & Cenge & KOG1578 & 4.2.1.1 & Carbonate dehydratase \\
\hline 12 & Cenge3.673061 & Cenge & KOG1578 & 4.2.1.1 & Carbonate dehydratase \\
\hline 13 & ClaPMI390.2054122 & ClaPMI390 & KOG1578 & 4.2.1.1 & Carbonate dehydratase \\
\hline 14 & Hebcy2.31455 & Hebcy & KOG1578 & 4.2.1.1 & Carbonate dehydratase \\
\hline 15 & Hebcy2.422688 & Hebcy & KOG1578 & 4.2.1.1 & Carbonate dehydratase \\
\hline 16 & Hebcy2.440671 & Hebcy & KOG1578 & 4.2.1.1 & Carbonate dehydratase \\
\hline 17 & Hebcy2.441841 & Hebcy & KOG1578 & 4.2.1.1 & Carbonate dehydratase \\
\hline 18 & Hebcy2.60663 & Hebcy & KOG1578 & 4.2.1.1 & Carbonate dehydratase \\
\hline 19 & Hebcy2.7784 & Hebcy & KOG1578 & 4.2.1.1 & Carbonate dehydratase \\
\hline 20 & Hymvar1.365650 & Hymvar & KOG1578 & 4.2.1.1 & Carbonate dehydratase \\
\hline 21 & Hymvar1.418299 & Hymvar & KOG1578 & 4.2.1.1 & Carbonate dehydratase \\
\hline 22 & Hymvar1.429608 & Hymvar & KOG0382 & 4.2.1.1 & Carbonate dehydratase \\
\hline 23 & Hymvar1.46314 & Hymvar & KOG1578 & 4.2.1.1 & Carbonate dehydratase \\
\hline 24 & Hymvar1.473328 & Hymvar & KOG0382 & 4.2.1.1 & Carbonate dehydratase \\
\hline 25 & Hymvar1.528692 & Hymvar & KOG0382 & 4.2.1.1 & Carbonate dehydratase \\
\hline 26 & Lacam2.106447 & Lacam & KOG0382 & 4.2.1.1 & Carbonate dehydratase \\
\hline 27 & Lacam2.245258 & Lacam & KOG1578 & 4.2.1.1 & Carbonate dehydratase \\
\hline 28 & Lacam2.672024 & Lacam & KOG1578 & 4.2.1.1 & Carbonate dehydratase \\
\hline 29 & Lacam2.677295 & Lacam & KOG1578 & 4.2.1.1 & Carbonate dehydratase \\
\hline 30 & Lacam2.86035 & Lacam & KOG1578 & 4.2.1.1 & Carbonate dehydratase \\
\hline 31 & Lacam2.96908 & Lacam & KOG0382 & 4.2.1.1 & Carbonate dehydratase \\
\hline 32 & Lacbi2.237838 & Lacbi & KOG0382 & 4.2.1.1 & Carbonate dehydratase \\
\hline 33 & Lacbi2.237860 & Lacbi & KOG0382 & 4.2.1.1 & Carbonate dehydratase \\
\hline 34 & Lacbi2.237880 & Lacbi & KOG0382 & 4.2.1.1 & Carbonate dehydratase \\
\hline 35 & Lacbi2.292325 & Lacbi & KOG1578 & 4.2.1.1 & Carbonate dehydratase \\
\hline 36 & Lacbi2.296408 & Lacbi & KOG1578 & 4.2.1.1 & Carbonate dehydratase \\
\hline 37 & Lacbi2.299838 & Lacbi & KOG1578 & 4.2.1.1 & Carbonate dehydratase \\
\hline 38 & Lacbi2.310771 & Lacbi & KOG1578 & 4.2.1.1 & Carbonate dehydratase \\
\hline 39 & Lacbi2.437952 & Lacbi & KOG0382 & 4.2.1.1 & Carbonate dehydratase \\
\hline 40 & Lacbi2.438072 & Lacbi & KOG0382 & 4.2.1.1 & Carbonate dehydratase \\
\hline 41 & Lacbi2.455107 & Lacbi & KOG0382 & 4.2.1.1 & Carbonate dehydratase \\
\hline 42 & Lacbi2.577322 & Lacbi & KOG0382 & 4.2.1.1 & Carbonate dehydratase \\
\hline 43 & Lacbi2.674253 & Lacbi & KOG1578 & 4.2.1.1 & Carbonate dehydratase \\
\hline 44 & Lacbi2.674272 & Lacbi & KOG1578 & 4.2.1.1 & Carbonate dehydratase \\
\hline 45 & Lacbi2.684751 & Lacbi & KOG1578 & 4.2.1.1 & Carbonate dehydratase \\
\hline 46 & Lacqui1.1597150 & Lacqui & KOG1578 & 4.2.1.1 & Carbonate dehydratase \\
\hline 47 & Lacvol1.1227871 & Lacvol & KOG1578 & 4.2.1.1 & Carbonate dehydratase \\
\hline 48 & Lacvol1.1446031 & Lacvol & KOG1578 & 4.2.1.1 & Carbonate dehydratase \\
\hline 49 & Lacvol1.1455320 & Lacvol & KOG1578 & 4.2.1.1 & Carbonate dehydratase \\
\hline 50 & Lacvol1.383293 & Lacvol & KOG1578 & 4.2.1.1 & Carbonate dehydratase \\
\hline 51 & Morel2.124836 & Morel & KOG1578 & 4.2.1.1 & Carbonate dehydratase \\
\hline 52 & Morel2.83280 & Morel & KOG1578 & 4.2.1.1 & Carbonate dehydratase \\
\hline 53 & Morel2.892886 & Morel & KOG0382 & 4.2.1.1 & Carbonate dehydratase \\
\hline 54 & Paxin1.106375 & Paxin & KOG1578 & 4.2.1.1 & Carbonate dehydratase \\
\hline
\end{tabular}




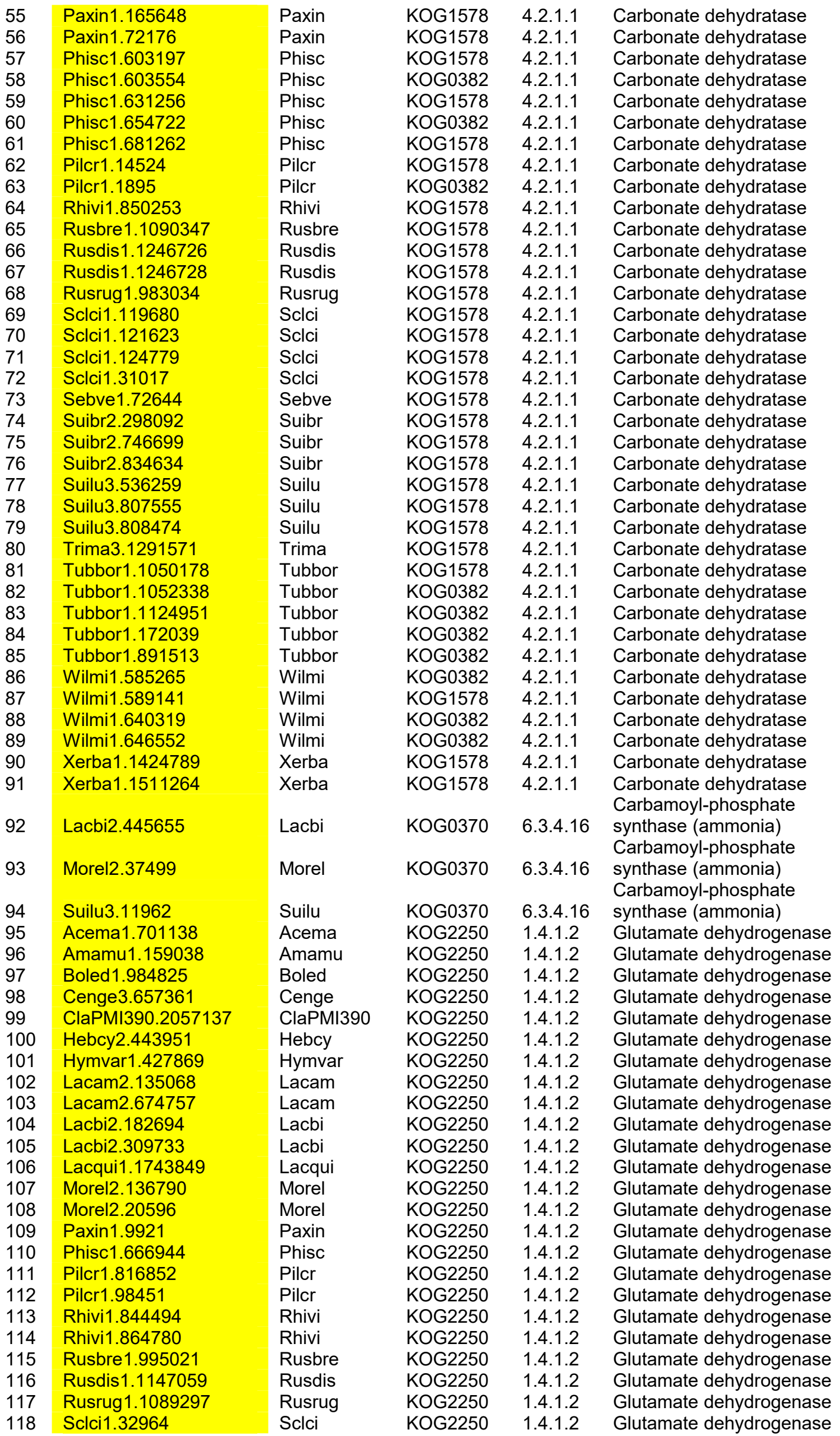




\begin{tabular}{|c|c|c|c|c|c|}
\hline 119 & Sebve1.15711 & Sebve & KOG2250 & 1.4.1.2 & Glutamate dehydrogenase \\
\hline 120 & Suibr2.824256 & Suibr & KOG2250 & 1.4.1.2 & Glutamate dehydrogenase \\
\hline 121 & Suibr2.842796 & Suibr & KOG2250 & 1.4.1.2 & Glutamate dehydrogenase \\
\hline 122 & Suilu3.72908 & Suilu & KOG2250 & 1.4.1.2 & Glutamate dehydrogenase \\
\hline 123 & Suilu3.798838 & Suilu & KOG2250 & 1.4.1.2 & Glutamate dehydrogenase \\
\hline 124 & Trima3.1425595 & Trima & KOG2250 & 1.4.1.2 & Glutamate dehydrogenase \\
\hline 125 & Tubbor1.1076602 & Tubbor & KOG2250 & 1.4.1.2 & Glutamate dehydrogenase \\
\hline 126 & Wilmi1.584754 & Wilmi & KOG2250 & 1.4.1.2 & Glutamate dehydrogenase \\
\hline 127 & Xerba1.1225020 & Xerba & KOG2250 & 1.4.1.2 & $\begin{array}{l}\text { Glutamate dehydrogenase } \\
\text { Glutamate dehydrogenase }\end{array}$ \\
\hline 128 & Acema1.690110 & Acema & KOG2250 & 1.4.1.4 & $\begin{array}{l}\text { (NADP+) } \\
\text { Glutamate dehydrogenase }\end{array}$ \\
\hline 129 & Cenge3.637358 & Cenge & KOG2250 & 1.4.1.4 & $\begin{array}{l}(\mathrm{NADP}+) \\
\text { Glutamate dehydrogenase }\end{array}$ \\
\hline 130 & ClaPMI390.2049040 & ClaPMI390 & KOG2250 & 1.4.1.4 & $\begin{array}{l}\text { (NADP }+) \\
\text { Glutamate dehydrogenase }\end{array}$ \\
\hline 131 & Hebcy2.78090 & Hebcy & KOG2250 & 1.4.1.4 & $\begin{array}{l}\text { (NADP+) } \\
\text { Glutamate dehydrogenase }\end{array}$ \\
\hline 132 & Hymvar1.235082 & Hymvar & KOG2250 & 1.4.1.4 & $\begin{array}{l}\text { (NADP+) } \\
\text { Glutamate dehydrogenase }\end{array}$ \\
\hline 133 & Lacam2.675815 & Lacam & KOG2250 & 1.4.1.4 & $\begin{array}{l}\text { (NADP+) } \\
\text { Glutamate dehydrogenase }\end{array}$ \\
\hline 134 & Lacbi2.292653 & Lacbi & KOG2250 & 1.4.1.4 & $\begin{array}{l}\text { (NADP+) } \\
\text { Glutamate dehydrogenase }\end{array}$ \\
\hline 135 & Morel2.131839 & Morel & KOG2250 & 1.4.1.4 & $\begin{array}{l}\text { (NADP+) } \\
\text { Glutamate dehydrogenase }\end{array}$ \\
\hline 136 & Morel2.132437 & Morel & KOG2250 & 1.4.1.4 & $\begin{array}{l}\text { (NADP+) } \\
\text { Glutamate dehydrogenase }\end{array}$ \\
\hline 137 & Phisc1.457315 & Phisc & KOG2250 & 1.4.1.4 & $\begin{array}{l}(\mathrm{NADP}+) \\
\text { Glutamate dehydrogenase }\end{array}$ \\
\hline 138 & Pilcr1.11511 & Pilcr & KOG2250 & 1.4.1.4 & $\begin{array}{l}(\mathrm{NADP}+) \\
\text { Glutamate dehydrogenase }\end{array}$ \\
\hline 139 & Sebve1.17555 & Sebve & KOG2250 & 1.4.1.4 & $\begin{array}{l}\text { (NADP+) } \\
\text { Glutamate dehydrogenase }\end{array}$ \\
\hline 140 & Trima3.1378607 & Trima3 & KOG2250 & 1.4.1.4 & $\begin{array}{l}\text { (NADP+) } \\
\text { Glutamate dehydrogenase }\end{array}$ \\
\hline 141 & Tubbor1.1068674 & Tubbor & KOG2250 & 1.4.1.4 & $\begin{array}{l}(\mathrm{NADP}+) \\
\text { Glutamate dehydrogenase }\end{array}$ \\
\hline 142 & Wilmi1.405230 & Wilmi & KOG2250 & 1.4.1.4 & $\begin{array}{l}(\mathrm{NADP}+) \\
\text { Glutamate synthase }\end{array}$ \\
\hline 143 & Acema1.737509 & Acema & KOG0399 & 1.4.1.13 & $\begin{array}{l}\text { (NADPH) } \\
\text { Glutamate synthase }\end{array}$ \\
\hline 144 & Amamu1.97466 & Amamu & KOG0399 & 1.4.1.13 & $\begin{array}{l}\text { (NADPH) } \\
\text { Glutamate synthase }\end{array}$ \\
\hline 145 & Boled1.899184 & Boled & KOG0399 & 1.4.1.13 & $\begin{array}{l}\text { (NADPH) } \\
\text { Glutamate synthase }\end{array}$ \\
\hline 146 & Cenge3.575254 & Cenge & KOG0399 & 1.4.1.13 & $\begin{array}{l}\text { (NADPH) } \\
\text { Glutamate synthase }\end{array}$ \\
\hline 147 & ClaPMI390.2077267 & ClaPMI390 & KOG0399 & 1.4.1.13 & $\begin{array}{l}\text { (NADPH) } \\
\text { Glutamate synthase }\end{array}$ \\
\hline 148 & Hebcy2.438587 & Hebcy & KOG0399 & 1.4.1.13 & $\begin{array}{l}\text { (NADPH) } \\
\text { Glutamate synthase }\end{array}$ \\
\hline 149 & Lacam2.674478 & Lacam & KOG0399 & 1.4.1.13 & $\begin{array}{l}\text { (NADPH) } \\
\text { Glutamate synthase }\end{array}$ \\
\hline 150 & Lacbi2.183838 & Lacbi & KOG0399 & 1.4.1.13 & $\begin{array}{l}\text { (NADPH) } \\
\text { Glutamate synthase }\end{array}$ \\
\hline 151 & Morel2.132072 & Morel & KOG0399 & 1.4.1.13 & $\begin{array}{l}\text { (NADPH) } \\
\text { Glutamate synthase }\end{array}$ \\
\hline 152 & Paxin1.73378 & Paxin & KOG0399 & 1.4.1.13 & $\begin{array}{l}\text { (NADPH) } \\
\text { Glutamate synthase }\end{array}$ \\
\hline 153 & Phisc1.691103 & Phisc & KOG0399 & 1.4.1.13 & $\begin{array}{l}\text { (NADPH) } \\
\text { Glutamate synthase }\end{array}$ \\
\hline 154 & Pilcr1.63545 & Pilcr & KOG0399 & 1.4.1.13 & $\begin{array}{l}\text { (NADPH) } \\
\text { Glutamate synthase }\end{array}$ \\
\hline 155 & Rhivi1.770144 & Rhivi & KOG0399 & 1.4.1.13 & $\begin{array}{l}\text { (NADPH) } \\
\text { Glutamate synthase }\end{array}$ \\
\hline 156 & Sclci1.1218577 & Sclci & KOG0399 & 1.4.1.13 & $(\mathrm{NADPH})$ \\
\hline
\end{tabular}




\begin{tabular}{|c|c|c|c|c|c|}
\hline 157 & Sebve1.327024 & Sebve & KOG0399 & 1.4.1.13 & $\begin{array}{l}\text { Glutamate synthase } \\
\text { (NADPH) } \\
\text { Glutamate synthase }\end{array}$ \\
\hline 158 & Suibr2.725303 & Suibr & KOG0399 & 1.4.1.13 & $\begin{array}{l}\text { (NADPH) } \\
\text { Glutamate synthase }\end{array}$ \\
\hline 159 & Suilu3.799154 & Suilu & KOG0399 & 1.4.1.13 & $\begin{array}{l}\text { (NADPH) } \\
\text { Glutamate synthase }\end{array}$ \\
\hline 160 & Trima3.1440003 & Trima & KOG0399 & 1.4.1.13 & $\begin{array}{l}\text { (NADPH) } \\
\text { Glutamate synthase }\end{array}$ \\
\hline 161 & Wilmi1.585891 & Wilmi & KOG0399 & 1.4.1.13 & $\begin{array}{l}\text { (NADPH) } \\
\text { Glutamate synthase }\end{array}$ \\
\hline 162 & Xerba1.1581850 & Xerba & KOG0399 & 1.4.1.13 & $(\mathrm{NADPH})$ \\
\hline 163 & Acema1.107182 & Acema & KOG0683 & 6.3.1.2 & Glutamate--ammonia ligase \\
\hline 164 & Acema1.361082 & Acema & KOG0683 & 6.3.1.2 & Glutamate--ammonia ligase \\
\hline 165 & Amamu1.166750 & Amamu & KOG0683 & 6.3.1.2 & Glutamate--ammonia ligase \\
\hline 166 & Amamu1.185211 & Amamu & KOG0683 & 6.3.1.2 & Glutamate--ammonia ligase \\
\hline 167 & Boled1.850637 & Boled & KOG0683 & 6.3.1.2 & Glutamate--ammonia ligase \\
\hline 168 & Boled1.912339 & Boled & KOG0683 & 6.3.1.2 & Glutamate--ammonia ligase \\
\hline 169 & Boled1.937395 & Boled & KOG0683 & 6.3.1.2 & Glutamate--ammonia ligase \\
\hline 170 & Cenge3.673039 & Cenge & KOG0683 & 6.3.1.2 & Glutamate--ammonia ligase \\
\hline 171 & Cenge3.680736 & Cenge & KOG0683 & 6.3.1.2 & Glutamate--ammonia ligase \\
\hline 172 & ClaPMI390.2053778 & ClaPMI390 & KOG0683 & 6.3. & Glutamate--ammonia ligase \\
\hline 173 & ClaPMI390.2059115 & ClaPMI390 & KOG0683 & 6.3.1.2 & Glutamate--ammonia ligase \\
\hline 174 & ClaPMI390.2076846 & ClaPMI390 & KOG0683 & 6.3.1.2 & Glutamate--ammonia ligase \\
\hline 175 & Hebcy2.438051 & Hebcy & KOG0683 & 6.3. & Glutamate--ammonia ligase \\
\hline 176 & Hebcy2.440776 & Hebcy & KOG0683 & 6.3.1.2 & Glutamate--ammonia ligase \\
\hline 177 & Hebcy2.64545 & Hebcy & KOG0683 & 6.3.1.2 & Glutamate--ammonia ligase \\
\hline 178 & Hymvar1.168440 & Hymvar & KOG0683 & 6.3.1.2 & Glutamate--ammonia ligase \\
\hline 179 & Hymvar1.394337 & Hymvar & KOG0683 & 6.3.1.2 & Glutamate--ammonia ligase \\
\hline 180 & Lacam2.102647 & Lacam & KOG0683 & 6.3.1.2 & Glutamate--ammonia ligase \\
\hline 181 & Lacam2.672562 & Lacam & KOG0683 & 6.3.1.2 & Glutamate--ammonia ligase \\
\hline 182 & Lacam2.680307 & Lacam & KOG0683 & 6.3.1.2 & Glutamate--ammonia ligase \\
\hline 183 & Lacbi2.183088 & Lacbi & KOG0683 & 6.3.1.2 & Glutamate--ammonia ligase \\
\hline 184 & Lacbi2.191578 & Lacbi & KOG0683 & 6.3.1.2 & Glutamate--ammonia ligase \\
\hline 185 & Lacbi2.299654 & Lacbi & KOG0683 & 6.3.1.2 & Glutamate--ammonia ligase \\
\hline 186 & Lacbi2.582908 & Lacbi & KOG0683 & 6.3.1.2 & Glutamate--ammonia ligase \\
\hline 187 & Lacbi2.684579 & Lacbi & KOG0683 & 6.3.1.2 & Glutamate--ammonia ligase \\
\hline 188 & Lacqui1.1652450 & Lacqui & KOG0683 & 6.3.1.2 & Glutamate--ammonia ligase \\
\hline 189 & Lacqui1.1772382 & Lacqui & KOG0683 & 6.3.1.2 & Glutamate--ammonia ligase \\
\hline 190 & Lacqui1.1779066 & Lacqui & KOG0683 & 6.3.1.2 & Glutamate--ammonia ligase \\
\hline 191 & Lacqui1.1787361 & Lacqui & KOG0683 & 6.3.1.2 & Glutamate--ammonia ligase \\
\hline 192 & Lacqui1.1831108 & Lacqui & KOG0683 & 6.3.1.2 & Glutamate--ammonia ligase \\
\hline 193 & Lacqui1.1877906 & Lacqui & KOG0683 & 6.3.1.2 & Glutamate--ammonia ligase \\
\hline 194 & Lacvol1.1122829 & Lacvol & KOG0683 & 6.3.1.2 & Glutamate--ammonia ligase \\
\hline 195 & Lacvol1.1161911 & Lacvol & KOG0683 & 6.3.1.2 & Glutamate--ammonia ligase \\
\hline 196 & Lacvol1.1284330 & Lacvol & KOG0683 & 6.3 . & Glutamate--ammonia ligase \\
\hline 197 & Lacvol1.1302828 & Lacvol & KOG0683 & 6.3 & Glutamate--ammonia ligase \\
\hline 198 & Lacvol1.1434703 & Lacvol & KOG0683 & 6.3 & ammonia ligase \\
\hline 199 & Morel2.156454 & Morel & KOG0683 & 6.3 & Glutamate--ammonia ligase \\
\hline 200 & Morel2.35934 & Morel & KOG0683 & 6.3.1.2 & Glutamate--ammonia ligase \\
\hline 201 & Paxin1.137295 & Paxin & KOG0683 & 6.3.1.2 & Glutamate--ammonia ligase \\
\hline 202 & Paxin1.166476 & Paxin & KOG0683 & 6.3.1.2 & Glutamate--ammonia ligase \\
\hline 203 & Paxin1.171414 & Paxin & KOG0683 & 6.3.1.2 & Glutamate--ammonia ligase \\
\hline 204 & Paxin1.74163 & Paxin & KOG0683 & 6.3.1.2 & Glutamate--ammonia ligase \\
\hline 205 & Phisc1.366317 & Phisc & KOG0683 & 6.3.1.2 & Glutamate--ammonia ligase \\
\hline 206 & Phisc1.684186 & Phisc & KOG0683 & 6.3.1.2 & Glutamate--ammonia ligase \\
\hline 207 & Phisc1.693711 & Phisc & KOG0683 & 6.3.1.2 & Glutamate--ammonia ligase \\
\hline 208 & Pilcr1.815449 & Pilcr & KOG0683 & 6.3.1.2 & Glutamate--ammonia ligase \\
\hline 209 & Pilcr1.823397 & Pilcr & KOG0683 & 6.3.1.2 & Glutamate--ammonia ligase \\
\hline 210 & Pilcr1.94641 & Pilcr & KOG0683 & 6.3.1.2 & Glutamate--ammonia ligase \\
\hline 211 & Rhivi1.777127 & Rhivi & KOG0683 & 6.3.1.2 & Glutamate--ammonia ligase \\
\hline 212 & Rhivi1.777798 & Rhivi & KOG0683 & 6.3.1.2 & Glutamate--ammonia ligase \\
\hline 213 & Rhivi1.846623 & Rhivi & KOG0683 & 6.3.1.2 & Glutamate--ammonia ligase \\
\hline 214 & Rhivi1.868145 & Rhivi & KOG0683 & 6.3.1.2 & Glutamate--ammonia ligase \\
\hline 215 & Rusbre1.73501 & Rusbre & KOG0683 & 6.3.1.2 & Glutamate--ammonia ligase \\
\hline 216 & Rusbre1.904848 & Rusbre & KOG0683 & 6.3.1.2 & Glutamate--ammonia ligase \\
\hline 217 & Rusbre1.981683 & Rusbre & KOG0683 & 6.3.1.2 & Glutamate--ammonia ligase \\
\hline
\end{tabular}




\begin{tabular}{|c|c|c|c|c|}
\hline 218 & Rusdis1.1181134 & Rusdis & KOG0683 & 6.3.1.2 \\
\hline 219 & Rusdis1.1221793 & Rusdis & KOG0683 & 6.3.1.2 \\
\hline 220 & Rusdis1.1310680 & Rusdis & KOG0683 & 6.3.1.2 \\
\hline 221 & Rusrug1.1088663 & Rusrug & KOG0683 & 6.3.1.2 \\
\hline 222 & Rusrug1.910820 & Rusrug & KOG0683 & 6.3.1.2 \\
\hline 223 & Rusrug1.948692 & Rusrug & KOG0683 & 6.3.1.2 \\
\hline 224 & Sclci1.106076 & Sclci & KOG0683 & 6.3.1.2 \\
\hline 225 & Sclci1.1209188 & Sclci & KOG0683 & 6.3.1.2 \\
\hline 226 & Sclci1.1212711 & Sclci & KOG0683 & 6.3.1.2 \\
\hline 227 & Sclci1.1224577 & Sclci & KOG0683 & 6.3.1.2 \\
\hline 228 & Sclci1.15356 & Sclci & KOG0683 & 6.3.1.2 \\
\hline 229 & Sebve1.331445 & Sebve & KOG0683 & 6.3.1.2 \\
\hline 230 & Sebve1.334244 & Sebve & KOG0683 & 6.3.1.2 \\
\hline 231 & Sebve1.68708 & Sebve & KOG0683 & 6.3 .1 .2 \\
\hline 232 & Suibr2.789626 & Suibr & KOG0683 & 6.3.1.2 \\
\hline 233 & Suibr2.838210 & Suibr & KOG0683 & 6.3.1.2 \\
\hline 234 & Suilu3.797877 & Suilu & KOG0683 & 6.3.1.2 \\
\hline 235 & Suilu3.806253 & Suilu & KOG0683 & 6.3.1.2 \\
\hline 236 & Trima3.1252879 & Trima & KOG0683 & 6.3.1.2 \\
\hline 237 & Trima3.1297256 & Trima & KOG0683 & 6.3.1.2 \\
\hline 238 & Trima3.1421346 & Trima & KOG0683 & 6.3.1.2 \\
\hline 239 & Tubbor1.1070453 & Tubbor & KOG0683 & 6.3.1. \\
\hline 240 & Tubbor1.1078486 & Tubbor & KOG0683 & 6.3.1. \\
\hline 241 & Tubbor1.1098919 & Tubbor & KOG0683 & 6.3 .1$. \\
\hline 242 & Wilmi1.588673 & Wilmi & KOG0683 & 6.3.1.2 \\
\hline 243 & Wilmi1.640447 & Wilmi & KOG0683 & 6.3.1.2 \\
\hline 244 & Xerba1.1453015 & Xerba & KOG0683 & 6.3.1.2 \\
\hline 245 & Xerba1.1512811 & Xerba & KOG0683 & 6.3.1.2 \\
\hline 246 & Xerba1.1606984 & Xerba & KOG0683 & 6.3.1.2 \\
\hline 247 & Xerba1.706248 & Xerba & KOG0683 & 6.3.1.2 \\
\hline 248 & Acema1.603847 & Acema & KOG0805 & 3.5.5.1 \\
\hline 249 & Acema1.618307 & Acema & KOG0805 & 3.5.5.1 \\
\hline 250 & Acema1.680622 & Acema & KOG0805 & 3.5.5.1 \\
\hline 251 & Acema1.795915 & Acema & KOG0805 & 3.5 .5 .1 \\
\hline 252 & Boled1.936652 & Boled & KOG0805 & 3.5.5.1 \\
\hline 253 & Cenge3.659460 & Cenge & KOG0805 & 3.5 .5 .1 \\
\hline 254 & Cenge3.679398 & Cenge & KOG0805 & 3.5 .5 .1 \\
\hline 255 & Cenge3.691736 & Cenge & KOG0805 & 3.5.5. \\
\hline 256 & ClaPMI390.2055397 & ClaPMI390 & KOG0805 & 3.5.5. \\
\hline 257 & Hymvar 1.368325 & Hymvar & KOG0805 & 3.5.5. \\
\hline 258 & Hymvar1.440437 & Hymvar & KOG0805 & 3.5 .5 \\
\hline 259 & Paxin1.174001 & Paxin & KOG0805 & 3.5.5 \\
\hline 260 & Phisc1.574080 & Phisc & KOG0805 & 3.5.5 \\
\hline 261 & Phisc1.661486 & Phisc & KOG0805 & 3.5 .5 \\
\hline 262 & Phisc1.678774 & Phisc & KOG0805 & 3.5.5. \\
\hline 263 & Phisc1.686126 & Phisc & KOG0805 & 3.5.5. \\
\hline 264 & Phisc1.687202 & Phisc & KOG0805 & 3.5 .5 . \\
\hline 265 & Pilcr1.827391 & Pilcr & KOG0805 & 3.5.5.1 \\
\hline 266 & Rhivi1.498787 & Rhivi & KOG0805 & 3.5.5.1 \\
\hline 267 & Suibr2.844573 & Suibr & KOG0805 & 3.5 .5 . \\
\hline 268 & Suilu3.800566 & Suilu & KOG0805 & 3.5.5. \\
\hline 269 & Tubbor1.79324 & Tubbor & KOG0805 & 3.5 .5 \\
\hline 270 & Tubbor1.977331 & Tubbor & KOG1231 & 3.5 .5 \\
\hline 271 & Wilmi1.660384 & Wilmi & KOG0805 & 3.5.5. \\
\hline 272 & Xerba1.1401665 & Xerba & KOG0805 & 3.5 .5 \\
\hline 273 & Acema1.394767 & Acema & KOG0682 & \\
\hline 274 & Acema1.491295 & Acema & KOG0682 & \\
\hline 275 & Acema1.577293 & Acema & KOG0682 & \\
\hline 276 & Acema1.578938 & Acema & KOG0682 & \\
\hline 277 & Acema1.598633 & Acema & KOG0682 & \\
\hline 278 & Acema1.601410 & Acema & KOG0682 & \\
\hline 279 & Acema1.673973 & Acema & KOG0682 & \\
\hline 280 & Acema1.681371 & Acema & KOG0682 & \\
\hline 281 & Acema1.731370 & Acema & KOG0682 & \\
\hline 282 & Amamu1.1040015 & Amamu & KOG0682 & \\
\hline 283 & Amamu1.178797 & Amamu & KOG0682 & \\
\hline & & Roled & & \\
\hline
\end{tabular}

Glutamate--ammonia ligase

Glutamate--ammonia ligase

Glutamate--ammonia ligase

Glutamate--ammonia ligase

Glutamate--ammonia ligase

Glutamate--ammonia ligase

Glutamate--ammonia ligase

Glutamate--ammonia ligase

Glutamate--ammonia ligase

Glutamate--ammonia ligase

Glutamate--ammonia ligase

Glutamate--ammonia ligase

Glutamate--ammonia ligase

Glutamate--ammonia ligase

Glutamate--ammonia ligase

Glutamate--ammonia ligase

Glutamate--ammonia ligase

Glutamate--ammonia ligase

Glutamate--ammonia ligase

Glutamate--ammonia ligase

Glutamate--ammonia ligase

Glutamate--ammonia ligase

Glutamate--ammonia ligase

Glutamate--ammonia ligase

Glutamate--ammonia ligase

Glutamate--ammonia ligase

Glutamate--ammonia ligase

Glutamate--ammonia ligase

Glutamate--ammonia ligase

Glutamate--ammonia ligase

Nitrilase

Nitrilase

Nitrilase

Nitrilase

Nitrilase

Nitrilase

Nitrilase

Nitrilase

Nitrilase

Nitrilase

Nitrilase

Nitrilase

Nitrilase

Nitrilase

Nitrilase

Nitrilase

Nitrilase

Nitrilase

Nitrilase

Nitrilase

Nitrilase

Nitrilase

Nitrilase

Nitrilase

Nitrilase

Ammonia permease

Ammonia permease

Ammonia permease

Ammonia permease

Ammonia permease

Ammonia permease

Ammonia permease

Ammonia permease

Ammonia permease

Ammonia permease

Ammonia permease

Ammonia permease 


\begin{tabular}{|c|c|c|c|}
\hline 285 & Boled1.908555 & Boled & KOG0682 \\
\hline 286 & Cenge3.560732 & Cenge & KOG0682 \\
\hline 287 & Cenge3.641073 & Cenge & KOG0682 \\
\hline 288 & Cenge3.649203 & Cenge & KOG0682 \\
\hline 289 & Cenge3.659613 & Cenge & KOG0682 \\
\hline 290 & Cenge3.679722 & Cenge & KOG0682 \\
\hline 291 & Cenge3.699790 & Cenge & KOG0682 \\
\hline 292 & ClaPMI390.2057426 & ClaPMI390 & KOG0682 \\
\hline 293 & ClaPMI390.2099573 & ClaPMI390 & KOG0682 \\
\hline 294 & ClaPMI390.2136878 & ClaPMI390 & KOG0682 \\
\hline 295 & ClaPMI390.2214031 & ClaPMI390 & KOG0682 \\
\hline 296 & Hebcy2.22652 & Hebcy & KOG0682 \\
\hline 297 & Hebcy2.249585 & Hebcy & KOG0682 \\
\hline 298 & Hebcy2.30318 & Hebcy & KOG0682 \\
\hline 299 & Hebcy2.76606 & Hebcy & KOG0682 \\
\hline 300 & Hymvar1.257858 & Hymvar & KOG0682 \\
\hline 301 & Hymvar1.376049 & Hymvar & KOG0682 \\
\hline 302 & Hymvar1.385003 & Hymvar & KOG0682 \\
\hline 303 & Hymvar1.390120 & Hymvar & KOG0682 \\
\hline 304 & Hymvar1.396501 & Hymvar & KOG0682 \\
\hline 305 & Hymvar1.433026 & Hymvar & KOG0682 \\
\hline 306 & Lacam2.108948 & Lacam & KOG0682 \\
\hline 307 & Lacam2.11646 & Lacam & KOG0682 \\
\hline 308 & Lacam2.1625650 & Lacam & KOG0682 \\
\hline 309 & Lacam2.182240 & Lacam & KOG0682 \\
\hline 310 & Lacam2.640142 & Lacam & KOG0682 \\
\hline 311 & Lacam2.677229 & Lacam & KOG0682 \\
\hline 312 & Lacam2.681776 & Lacam & KOG0682 \\
\hline 313 & Lacbi2.188643 & Lacbi & KOG0682 \\
\hline 314 & Lacbi2.190906 & Lacbi & KOG0682 \\
\hline 315 & Lacbi2.255304 & Lacbi & KOG0682 \\
\hline 316 & Lacbi2.300932 & Lacbi & KOG0682 \\
\hline 317 & Lacbi2.313221 & Lacbi & KOG0682 \\
\hline 318 & Lacbi2.331747 & Lacbi & KOG0682 \\
\hline 319 & Lacbi2.484007 & Lacbi & KOG0682 \\
\hline 320 & Lacqui1.1719837 & Lacqui & KOG0682 \\
\hline 321 & Lacvol1.1305322 & Lacvol & KOG0682 \\
\hline 322 & Lacvol1.1362652 & Lacvol & KOG0682 \\
\hline 323 & Morel2.104564 & Morel & KOG0682 \\
\hline 324 & Morel2.116310 & Morel & KOG0682 \\
\hline 325 & Morel2.93236 & Morel & KOG0682 \\
\hline 326 & Paxin1.16099 & Paxin & KOG0682 \\
\hline 327 & Paxin1.164643 & Paxin & KOG0682 \\
\hline 328 & Phisc1.198700 & Phisc & KOG0682 \\
\hline 329 & Phisc1.457340 & Phisc & KOG0682 \\
\hline 330 & Phisc1.55504 & Phisc & KOG0682 \\
\hline 331 & Phisc1.574918 & Phisc & KOG0682 \\
\hline 332 & Phisc1.618579 & Phisc & KOG0682 \\
\hline 333 & Phisc1.680050 & Phisc & KOG0682 \\
\hline 334 & Phisc1.682250 & Phisc & KOG0682 \\
\hline 335 & Phisc1.789950 & Phisc & KOG0682 \\
\hline 336 & Phisc1.84323 & Phisc & KOG0682 \\
\hline 337 & Pilcr1.65373 & Pilcr & KOG0682 \\
\hline 338 & Pilcr1.693189 & Pilcr & KOG0682 \\
\hline 339 & Pilcr1.71308 & Pilcr & KOG0682 \\
\hline 340 & Pilcr1.773636 & Pilcr & KOG0682 \\
\hline 341 & Pilcr1.815462 & Pilcr & KOG0682 \\
\hline 342 & Pilcr1.818299 & Pilcr & KOG0682 \\
\hline 343 & Pilcr1.826791 & Pilcr & KOG0682 \\
\hline 344 & Rhivi1.680885 & Rhivi & KOG0682 \\
\hline 345 & Rhivi1.801313 & Rhivi & KOG0682 \\
\hline 346 & Rhivi1.814607 & Rhivi & KOG0682 \\
\hline 347 & Rhivi1.865633 & Rhivi & KOG0682 \\
\hline 348 & Rusbre1.969632 & Rusbre & KOG0682 \\
\hline 349 & Rusdis 1.1171474 & Rusdis & KOG0682 \\
\hline 350 & Rusrug1.1185715 & Rusrug & KOG0682 \\
\hline & & & \\
\hline
\end{tabular}

Ammonia permease Ammonia permease Ammonia permease Ammonia permease Ammonia permease Ammonia permease Ammonia permease Ammonia permease Ammonia permease Ammonia permease Ammonia permease Ammonia permease Ammonia permease Ammonia permease Ammonia permease Ammonia permease Ammonia permease Ammonia permease Ammonia permease Ammonia permease Ammonia permease Ammonia permease Ammonia permease Ammonia permease Ammonia permease Ammonia permease Ammonia permease Ammonia permease Ammonia permease Ammonia permease Ammonia permease Ammonia permease Ammonia permease Ammonia permease Ammonia permease Ammonia permease Ammonia permease Ammonia permease Ammonia permease Ammonia permease Ammonia permease Ammonia permease Ammonia permease Ammonia permease Ammonia permease Ammonia permease Ammonia permease Ammonia permease Ammonia permease Ammonia permease Ammonia permease Ammonia permease Ammonia permease Ammonia permease Ammonia permease Ammonia permease Ammonia permease Ammonia permease Ammonia permease Ammonia permease Ammonia permease Ammonia permease Ammonia permease Ammonia permease Ammonia permease Ammonia permease Ammonia permease 


\begin{tabular}{lllll}
352 & Sclci1.1218182 & Sclci & KOG0682 & Ammonia permease \\
353 & Sclci1.14567 & Sclci & KOG0682 & Ammonia permease \\
354 & Sclci1.852123 & Sclci & KOG0682 & Ammonia permease \\
355 & Sebve1.325740 & Sebve & KOG0682 & Ammonia permease \\
356 & Sebve1.327041 & Sebve & KOG0682 & Ammonia permease \\
357 & Suibr2.771835 & Suibr & KOG0682 & Ammonia permease \\
358 & Suibr2.786410 & Suibr & KOG0682 & Ammonia permease \\
359 & Suibr2.845958 & Suibr & KOG0682 & Ammonia permease \\
360 & Suilu3.758484 & Suilu & KOG0682 & Ammonia permease \\
361 & Suilu3.801647 & Suilu & KOG0682 & Ammonia permease \\
362 & Suilu3.811475 & Suilu & KOG0682 & Ammonia permease \\
363 & Trima3.1377724 & Trima & KOG0682 & Ammonia permease \\
364 & Trima3.1426836 & Trima & KOG0682 & Ammonia permease \\
365 & Tubbor1.1100749 & Tubbor & KOG0682 & Ammonia permease \\
366 & Tubbor1.1122825 & Tubbor & KOG0682 & Ammonia permease \\
367 & Tubbor1.979267 & Tubbor & KOG0682 & Ammonia permease \\
368 & Wilmi1.536895 & Wilmi & KOG0682 & Ammonia permease \\
369 & Wilmi1.593102 & Wilmi & KOG0682 & Ammonia permease \\
370 & Wilmi1.634883 & Wilmi & KOG0682 & Ammonia permease \\
371 & Wilmi1.663800 & Wilmi & KOG0682 & Ammonia permease \\
372 & Xerba1.1057860 & Xerba & KOG0682 & Ammonia permease \\
373 & Xerba1.1489382 & Xerba & KOG0682 & Ammonia permease \\
374 & Xerba1.1505423 & Xerba & KOG0682 & Ammonia permease \\
\hline
\end{tabular}


Appendix Table 3.6 Common genes to $\mathrm{A}$ and $\mathrm{H}$ among differentially expressed genes

\begin{tabular}{|c|c|c|c|c|c|c|c|c|c|}
\hline & \multirow[t]{2}{*}{ Fasyl ID } & \multirow[t]{2}{*}{ AGI ID } & \multirow[t]{2}{*}{ Putative function } & \multicolumn{2}{|c|}{$\mathrm{H}-\mathrm{S}$} & \multicolumn{2}{|c|}{$\mathrm{H}-\mathrm{A}$} & \multicolumn{2}{|c|}{ S-A } \\
\hline & & & & Log2fc & p value* & Log2fc & $p$ value* & Log2fc & $p$ value* \\
\hline 1 & Fasyl ID & AGI ID & Putative function & $\log 2 \mathrm{fc} 1.2$ & padj1.2 & $\log 2 \mathrm{fc} 1.3$ & padj1.3 & $\log 2 \mathrm{fc} 2.3$ & padj2.3 \\
\hline 2 & fasyl_1232754 & AT1G78780 & pathogenesis-related family protein & -0.95 & 0.04 & 0.43 & 1.00 & 1.37 & 0.00 \\
\hline 3 & fasyl_1905152 & AT1G78780 & pathogenesis-related family protein & -1.07 & 0.01 & 0.47 & 1.00 & 1.54 & 0.00 \\
\hline 4 & fasyl_2556709 & AT5G35450 & $\begin{array}{l}\text { Disease resistance protein (CC-NBS-LRR class) } \\
\text { family }\end{array}$ & 1.64 & 0.00 & 0.17 & 1.00 & -1.47 & 0.03 \\
\hline 5 & fasyl_0654506 & AT2G46150 & $\begin{array}{l}\text { Late embryogenesis abundant (LEA) hydroxyproline- } \\
\text { rich glycoprotein family }\end{array}$ & 1.76 & 0.00 & 0.48 & 1.00 & -1.28 & 0.04 \\
\hline 6 & fasyl_2568183 & AT1G69870 & nitrate transporter 1.7 & -1.45 & 0.00 & 0.38 & 1.00 & 1.83 & 0.00 \\
\hline 7 & fasyl_1051267 & AT2G38940 & phosphate transporter $1 ; 4$ & 0.91 & 0.01 & 0.02 & 1.00 & -0.89 & 0.04 \\
\hline 8 & fasyl_2568106 & AT3G54700 & phosphate transporter $1 ; 7$ & 0.89 & 0.01 & -0.17 & 1.00 & -1.06 & 0.01 \\
\hline 9 & fasyl_1656484 & AT2G01770 & vacuolar iron transporter 1 & -2.98 & 0.00 & 0.06 & 1.00 & 3.04 & 0.00 \\
\hline 10 & fasyl_0020415 & AT1G23090 & sulfate transporter 91 & 1.28 & 0.01 & 0.02 & 1.00 & -1.27 & 0.04 \\
\hline 11 & fasyl_1187318 & AT1G07750 & RmIC-like cupins superfamily protein & 0.94 & 0.01 & -0.03 & 1.00 & -0.97 & 0.03 \\
\hline 12 & fasyl_1007580 & AT3G63060 & EID1-like 3 & 1.92 & 0.00 & 0.48 & 1.00 & -1.44 & 0.02 \\
\hline 13 & fasyl_0279451 & AT2G37570 & HSP20-like chaperones superfamily protein & -0.50 & 0.02 & 0.18 & 1.00 & 0.67 & 0.00 \\
\hline 14 & fasyl_0096454 & AT3G59410 & protein kinase family protein & 0.74 & 0.05 & -0.15 & 1.00 & -0.89 & 0.04 \\
\hline 15 & fasyl_1122409 & AT3G21420 & $\begin{array}{l}\text { 2-oxoglutarate (2OG) and Fe(II)-dependent } \\
\text { oxygenase superfamily protein }\end{array}$ & -1.09 & 0.02 & 0.07 & 1.00 & 1.16 & 0.05 \\
\hline 16 & fasyl_2214162 & AT5G08380 & alpha-galactosidase 1 & 1.35 & 0.00 & 0.23 & 1.00 & -1.12 & 0.03 \\
\hline 17 & fasyl_0405854 & AT4G27450 & Aluminium induced protein with YGL and LRDR motifs & 1.51 & 0.00 & 0.33 & 1.00 & -1.18 & 0.03 \\
\hline 18 & fasyl_0720251 & AT2G37570 & HSP20-like chaperones superfamily protein & -0.56 & 0.01 & 0.07 & 1.00 & 0.62 & 0.02 \\
\hline 19 & fasyl_2564988 & AT4G25433 & peptidoglycan-binding LysM domain-containing protein & -1.15 & 0.02 & 0.10 & 1.00 & 1.25 & 0.04 \\
\hline 20 & fasyl_2380254 & AT3G23640 & heteroglycan glucosidase 1 & -0.62 & 0.00 & -0.04 & 1.00 & 0.58 & 0.02 \\
\hline 21 & fasyl_1295410 & AT5G06080 & LOB domain-containing protein 33 & -1.77 & 0.00 & -0.10 & 1.00 & 1.67 & 0.00 \\
\hline 22 & fasyl_2562105 & AT1G07150 & mitogen-activated protein kinase kinase kinase 13 & 1.30 & 0.00 & -0.10 & 1.00 & -1.40 & 0.01 \\
\hline 23 & fasyl_0957303 & AT2G38830 & Ubiquitin-conjugating enzyme/RWD-like protein & 1.95 & 0.00 & 0.51 & 1.00 & -1.44 & 0.05 \\
\hline
\end{tabular}

H, Hainich-Dün; S, Schorfheide-Chorin; A, Schwäbische Alb

Log2fc: $\log _{2}$ fold change, ${ }^{*}$ Adjusted $p$ value 


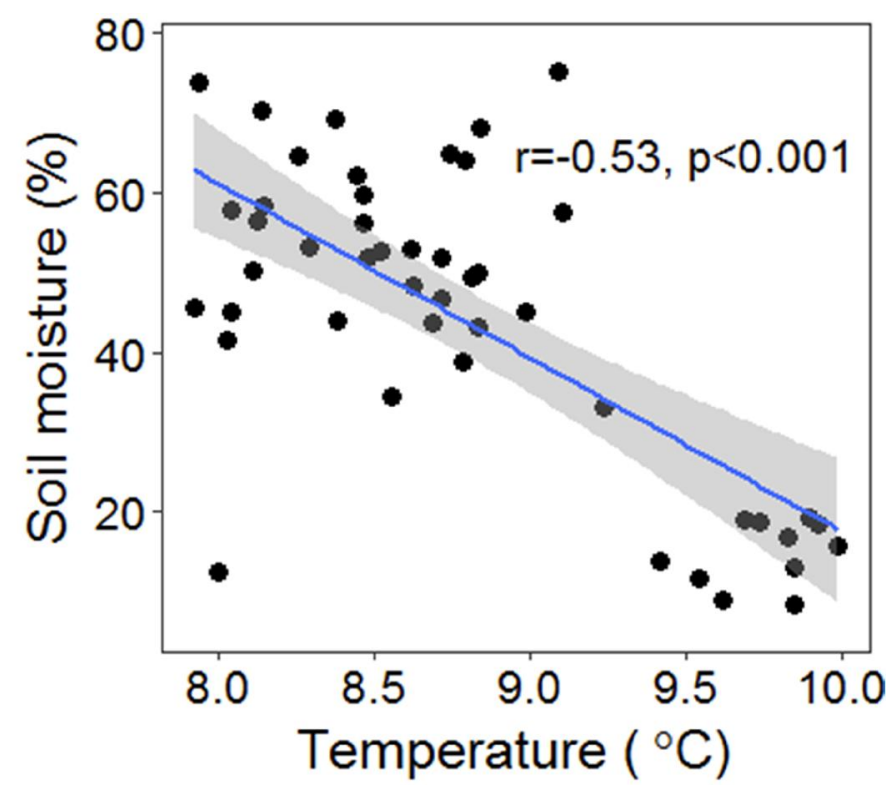

Appendix Fig. 4.1 Correlation between soil moisture and annual mean temperature in forest plots across Germany in 2014. Pearson correlation coefficient ( $r$ ) with the associated $P$ value is shown. 


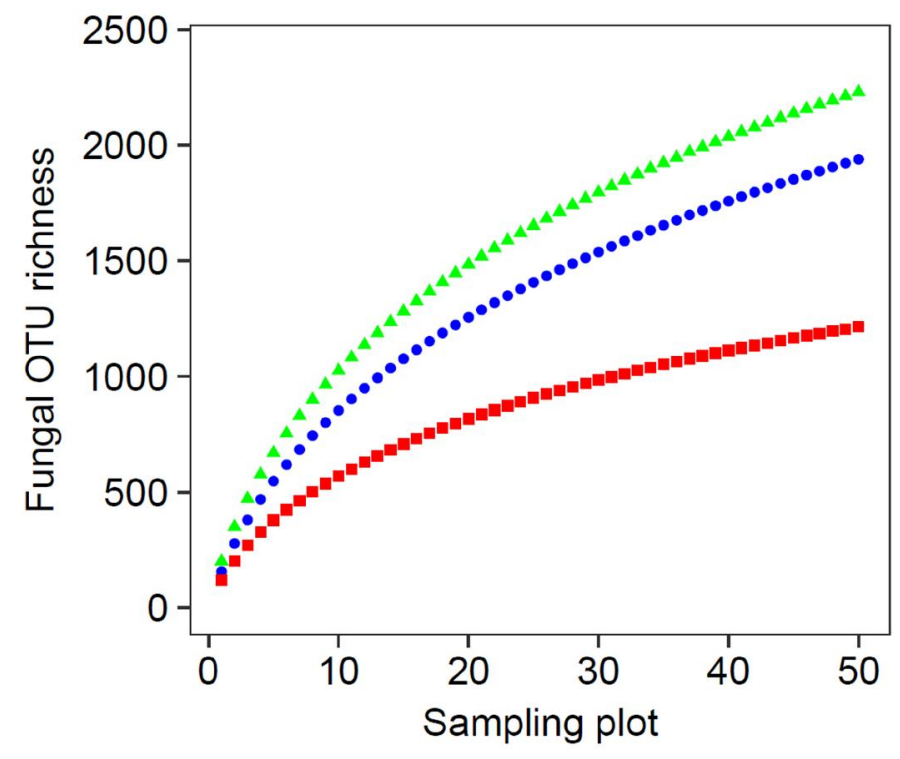

Appendix Fig. 4.2 Rarefaction curves depicting the fungal operational taxonomic unit (OTU) richness in 50 forest plots for each study region: Schwäbische Alb (blue), Hainich-Dün (green) and Schorfheide-Chorin (red). 


\begin{tabular}{|c|c|c|c|c|c|c|c|c|c|}
\hline \multirow[b]{3}{*}{ Soil N } & \multicolumn{3}{|c|}{ A } & \multicolumn{3}{|c|}{$\mathrm{H}$} & \multicolumn{3}{|c|}{ s } \\
\hline & SYM & SAP & PAT & SYM & SAP & PAT & SYM & SAP & PAT \\
\hline & & & & 0.023 & & 0.036 & & 0.024 & \\
\hline Soil NH4 & & & & & & & & & \\
\hline Soil NO3 & & & & & & & 0.003 & & 0.005 \\
\hline Soil water & & & & & & & 0.016 & & \\
\hline Root C & & & & 0.006 & & & & & \\
\hline Root glucose & & & 0.011 & & & & & & \\
\hline Root starch & & & & & & 0.007 & & 0.003 & \\
\hline Root N & & & & 0.003 & & 0.011 & & & \\
\hline Root NH4 & 0.000 & 0.005 & 0.007 & & & & & & \\
\hline Root NO3 & 0.016 & 0.002 & & & & 0.034 & 0.005 & 0.000 & \\
\hline
\end{tabular}

Appendix Fig. 4.3 Significant relationships between soil and root chemistry and the read abundance of root-associated trophic groups in the three study regions. SYM=symbiotroph, SAP=saprotroph and PAT=pathotroph. $A=$ Schwäbische Alb, $H=$ Hainich-Dün and $S=$ Schorfheide-Chorin. Blue colors indicate negative correlations while red colors stand for positive correlations. $P$ values were represented numerically where significant effects were found. 


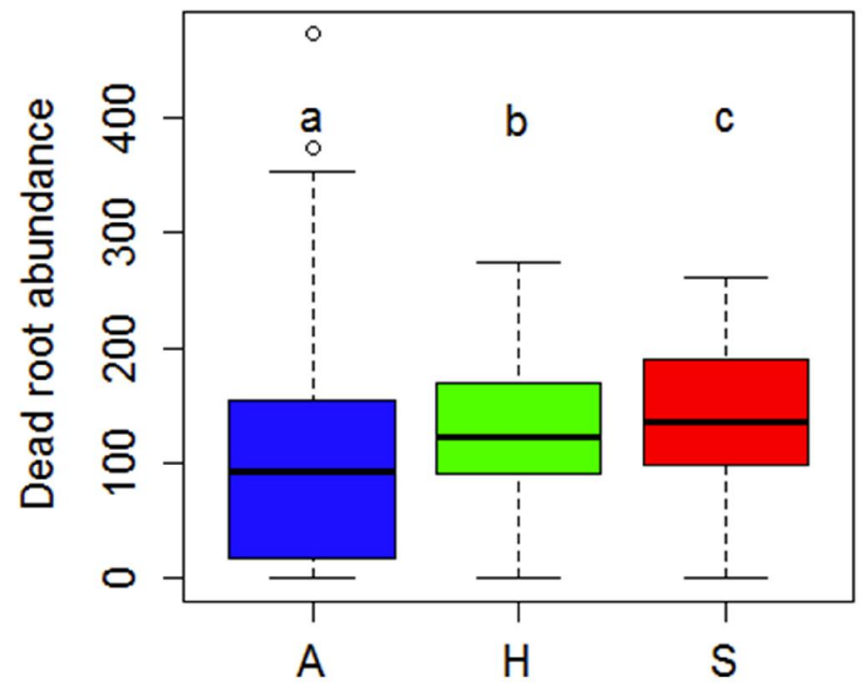

Appendix Fig. 4.4 Mean abundance of dead root tips per plot $(n=30)$ in the three biogeographical regions. $A=$ Schwäbische Alb, $H=$ Hainich-Dün and $S=$ SchorfheideChorin. Different small letters indicate significant difference among the means of the three regions at the $1 \%$ level. 
Appendix Table 4.1 Mean read abundance and OTU richness of root-associated fungal trophic groups in three biogeographic regions. $A=$ Schwäbische $A l b, H=$ Hainich-Dün, and $S=$ Schorfheide-Chorin. SYM = symbiotroph, SAP = saprotroph, PAT = pathotroph and UNK = unknown fungi. Data were analyzed with generalized linear model (Poisson regression). Significant differences at $p<0.05$ are indicated with bold letters. Data are means of $n=50$ plots per region \pm SE.

\begin{tabular}{|c|c|c|c|c|c|c|c|}
\hline \multirow[t]{2}{*}{ Trophic mode } & \multicolumn{3}{|c|}{ Study region } & \multicolumn{4}{|c|}{$P$ value } \\
\hline & $A$ & $\mathrm{H}$ & $S$ & A-H-S & A-H & A-S & $\mathrm{H}-\mathrm{S}$ \\
\hline \multicolumn{8}{|c|}{$\begin{array}{l}\text { Mean reads per } \\
\text { plot }\end{array}$} \\
\hline SYM & $4827 \pm 202$ & $5031 \pm 125$ & $3573 \pm 203$ & $<0.001$ & $<0.001$ & $<0.001$ & $<0.001$ \\
\hline SAP & $821 \pm 149$ & $746 \pm 71$ & $1150 \pm 137$ & $<0.001$ & $<0.001$ & $<0.001$ & $<0.001$ \\
\hline PAT & $89 \pm 17$ & $145 \pm 26$ & $523 \pm 79$ & $<0.001$ & $<0.001$ & $<0.001$ & $<0.001$ \\
\hline UNK & $2663 \pm 159$ & $2479 \pm 139$ & $3154 \pm 166$ & $<0.001$ & $<0.001$ & $<0.001$ & $<0.001$ \\
\hline \multicolumn{8}{|c|}{$\begin{array}{l}\text { Mean numbers of } \\
\text { OTUs per plot }\end{array}$} \\
\hline SYM & $47 \pm 2$ & $62 \pm 3$ & $27 \pm 1$ & $<0.001$ & $<.001$ & $<0.001$ & $<0.001$ \\
\hline SAP & $30 \pm 2$ & $34 \pm 2$ & $26 \pm 1$ & $<0.001$ & $<0.001$ & $<0.001$ & $<0.001$ \\
\hline PAT & $9 \pm 1$ & $15 \pm 1$ & $10 \pm 1$ & $<0.001$ & $<0.001$ & 0.251 & $<0.001$ \\
\hline UNK & $70 \pm 3$ & $89 \pm 3$ & $56 \pm 2$ & $<0.001$ & $<0.001$ & $<0.001$ & $<0.001$ \\
\hline
\end{tabular}


Appendix Table 4.2 Characterization and statistical analyses of mean relative abundance of fungal orders per plot in three biogeographical regions. $A=$ Schwäbische Alb, $H=$ Hainich-Dün and $S=$ Schorfheide-Chorin. Orders with a relative abundance $<0.1 \%$ are grouped in Others. Significant differences at $p<0.05$ are indicated with bold letters. Data are means of $n=50$ plots per region \pm SE.

\begin{tabular}{|c|c|c|c|c|c|c|c|}
\hline \multirow[t]{2}{*}{ Order } & \multicolumn{3}{|c|}{ Study region } & \multicolumn{4}{|c|}{$p$ value } \\
\hline & A & $\mathrm{H}$ & $\mathrm{S}$ & A-H-S & $\mathrm{A}-\mathrm{H}$ & A-S & $\mathrm{H}-\mathrm{S}$ \\
\hline \multicolumn{8}{|l|}{ Basidiomycota } \\
\hline Agaricales & $2732 \pm 197$ & $2213 \pm 190$ & $1669 \pm 122$ & $<0.001$ & $<0.001$ & $<0.001$ & $<0.001$ \\
\hline Russulales & $1448 \pm 206$ & $2507 \pm 256$ & $2570 \pm 211$ & $<0.001$ & $<0.001$ & $<0.001$ & $<0.001$ \\
\hline Sebacinales & $727 \pm 137$ & $456 \pm 92$ & $1 \pm 0.5$ & $<0.001$ & $<0.001$ & $<0.001$ & $<0.001$ \\
\hline Atheliales & $517 \pm 117$ & $242 \pm 73$ & $93 \pm 30$ & $<0.001$ & $<0.001$ & $<0.001$ & $<0.001$ \\
\hline Thelephorales & $482 \pm 73$ & $507 \pm 66$ & $187 \pm 61$ & $<0.001$ & $<0.001$ & $<0.001$ & $<0.001$ \\
\hline Trechisporales & $68 \pm 25$ & $107 \pm 30$ & $435 \pm 71$ & $<0.001$ & $<0.001$ & $<0.001$ & $<0.001$ \\
\hline Boletales & $28 \pm 9$ & $182 \pm 57$ & $305 \pm 58$ & $<0.001$ & $<0.001$ & $<0.001$ & $<0.001$ \\
\hline Cantharellales & $146 \pm 55$ & $192 \pm 46$ & $24 \pm 12$ & $<0.001$ & $<0.001$ & $<0.001$ & $<0.001$ \\
\hline Polyporales & $34 \pm 18$ & $58 \pm 29$ & $23 \pm 15$ & $<0.001$ & $<0.001$ & $<0.001$ & $<0.001$ \\
\hline Auriculariales & $4 \pm 1$ & $7 \pm 2$ & $39 \pm 30$ & $<0.001$ & $<0.001$ & $<0.001$ & $<0.001$ \\
\hline \multicolumn{8}{|l|}{ Ascomycota } \\
\hline Helotiales & $565 \pm 59$ & $455 \pm 39$ & $1698 \pm 88$ & $<0.001$ & $<0.001$ & $<0.001$ & $<0.001$ \\
\hline Pezizales & $413 \pm 75$ & $574 \pm 64$ & $290 \pm 64$ & $<0.001$ & $<0.001$ & $<0.001$ & $<0.001$ \\
\hline Archaeorhizomycetales & $31 \pm 14$ & $3 \pm 1$ & $301 \pm 90$ & $<0.001$ & $<0.001$ & $<0.001$ & $<0.001$ \\
\hline Chaetothyriales & $64 \pm 11$ & $79 \pm 15$ & $34 \pm 5$ & $<0.001$ & $<0.001$ & $<0.001$ & $<0.001$ \\
\hline Pleosporales & $48 \pm 12$ & $27 \pm 5$ & $18 \pm 8$ & $<0.001$ & $<0.001$ & $<0.001$ & $<0.001$ \\
\hline Xylariales & $47 \pm 21$ & $9 \pm 2$ & $11 \pm 3$ & $<0.001$ & $<0.001$ & $<0.001$ & 0.038 \\
\hline Capnodiales & $2 \pm 1$ & $15 \pm 6$ & $33 \pm 6$ & $<0.001$ & $<0.001$ & $<0.001$ & $<0.001$ \\
\hline Rhytismatales & $1.2 \pm 0.8$ & $0.2 \pm 0.1$ & $28 \pm 10$ & $<0.001$ & $<0.001$ & $<0.001$ & $<0.001$ \\
\hline Hysteriales & $18 \pm 8$ & $24 \pm 6$ & $25 \pm 5$ & $<0.001$ & $<0.001$ & $<0.001$ & 0.500 \\
\hline Hypocreales & $19 \pm 7$ & $15 \pm 4$ & $4 \pm 1$ & $<0.001$ & $<0.001$ & $<0.001$ & $<0.001$ \\
\hline \multicolumn{8}{|l|}{ Glomeromycota } \\
\hline $\begin{array}{l}\text { Glomerales } \\
\text { Zygomycota }\end{array}$ & $325 \pm 84$ & $176 \pm 42$ & $27 \pm 12$ & $<0.001$ & $<0.001$ & $<0.001$ & $<0.001$ \\
\hline Mortierellales & $15 \pm 2$ & $15 \pm 1$ & $13 \pm 1$ & $<0.001$ & $<0.001$ & $<0.001$ & $<0.001$ \\
\hline \multicolumn{8}{|l|}{ Chytridiomycota } \\
\hline Chytridiales & $30 \pm 29$ & $1 \pm 0$ & $1 \pm 0$ & $<0.001$ & $<0.001$ & $<0.001$ & 0.626 \\
\hline Others & $148 \pm 21$ & $129 \pm 19$ & $168 \pm 28$ & $<0.001$ & $<0.001$ & $<0.001$ & $<0.001$ \\
\hline Unidentified & $485 \pm 58$ & $407 \pm 57$ & $402 \pm 48$ & $<0.001$ & $<0.001$ & $<0.001$ & 0.407 \\
\hline
\end{tabular}




\section{Declarations of the author's contributions}

\section{Chapter 2}

Quang Dung Nguyen conducted the measurements of beech performance, characterized and identified ectomycorrhizal communities, conducted ${ }^{15} \mathrm{~N}$ labeling experiment, analyzed data and wrote the manuscript draft. Rodica Pena planned and set up the experiment. Nitrogen isotope analysis was conducted at Centre for Stable Isotope Research and Analysis, University of Göttingen with the support of Lars Szwec. Andrea Polle designed the study, supervised data analyses and contributed to the writing of the manuscript.

\section{Chapter 3}

Quang Dung Nguyen participated in field harvests and collected fine root samples in the three study regions, extracted RNA from the roots, analyzed the RNA-Seq data, wrote this chapter. RNA sequencing was done by Chronix Biomedical $\mathrm{GmbH}$, Göttingen, Germany with the support of Julia Beck. Dennis Janz did the bioinformatic analysis of RNA-Seq data. Andrea Polle designed the study, supervised the data analyses and writing of the chapter

\section{Chapter 4}

Quang Dung Nguyen sampled fine roots in Schorfheide-Chorin, conducted the root measurements (root $\mathrm{N}$ and $\mathrm{C}$, root carbohydrates), extracted DNA and prepared DNA amplicon, analyzed data and wrote the chapter. Root $\mathrm{NH}_{4}{ }^{+}$and $\mathrm{NO}_{3}{ }^{-}$were measured by Jan-Lukas Barke. Rodica Pena and Silke Ammerschubert samped fine roots in Hanich-Dün and Schwäbische Alb, respectively. Illumina amplicon sequencing, DNA sequence processing and bioinformatic analysis were conducted at Department of Genomic and Applied Microbiology, University of Göttingen with the support of Andrea Thürmer, Dominik Schneider and Rolf Daniel. Bin Song and Rodica Pena measured soil $\mathrm{NH}_{4+}$ and $\mathrm{NO}_{3}{ }^{-}$variables. Ingo Schöning provided soil carbon and nitrogen, soil $\mathrm{pH}$ and soil water content. $\mathrm{N}$ deposition data were provided by Sophia Leimer, Martin T. Schwarz and Wolfgang Wilcke. Andrea Polle designed the study, supervised data analyses and the writing of this chapter. 


\section{Scientific activities during the PhD studies}

\section{Publications}

Nguyen DQ, Pena R, Polle A (2017). Impact of ectomycorrhizal community composition and soil treatment on inorganic nitrogen nutrition and performance of beech (Fagus sylvatica L.) provenances. Trees, 31: 1891-1904 doi: https://doi.org/10.1007/s00468-017-1594-7

\section{Presentations}

Nguyen DQ (2018) Diversity and function of root-associated fungal communities in relation to nitrogen nutrition in temperate forests. Forstbotanisches Seminar, Department of Forest Botany and Tree Physiology, University of Göttingen, Germany (14 May 2018)

Nguyen DQ, Song B, Pena R, Janz D, Brinkmann N, Schneider D, Daniel R, Polle A (2017) Nitrogen and root mycobiome in temperate forests along a geographical gradient. $9^{\text {th }}$ International Conference on Mycorrhiza. Prague, Czech Republic (30 Jul-4 Aug 2017)

Nguyen DQ (2017) Root fungal communities and nutrient profile in temperate forests across Germany. Forstbotanisches Seminar, Department of Forest Botany and Tree Physiology, University of Göttingen, Germany (3 Jul 2017)

Nguyen DQ, Ammerschubert S, Song B, Pena R, Müller M, Polle A (2016) Functional diversity of mycorrhiza in relation to land-use changes and ecosystem functions. $14^{\text {th }}$ Assembly of the Biodiversity Exploratories, Wernigerode, Germany (21-24 Feb 2017)

Nguyen DQ, Ammerschubert S, Schröter K, Polle A (2016) Diversity of ectomycorrhizal fungi in relation to land-use changes and ecosystem functions. $13^{\text {th }}$ Assembly of the Biodiversity Exploratories, Wernigerode, Germany (16-19 Feb 2016)

Nguyen DQ (2015) Soil organism-beech interaction in relation to nitrogen uptake. Forstbotanisches Seminar, Department of Forest Botany and Tree Physiology, University of Göttingen, Germany (2 Feb 2015)

\section{Posters}


Nguyen DQ, Schneider D, Song B, Brinkmann N, Janz D, Schöning I, Pena R, Daniel R, Polle A (2018) Root-associated fungal communities and their relationships with root and soil carbon and nitrogen in temperate forests. $15^{\text {th }}$ Assembly of the Biodiversity Exploratories, Wernigerode, Germany (20-23 Feb 2018)

Nguyen DQ, Pena R, Song B, Polle A (2017) Carbon and nitrogen concentrations of fine roots in forests across the Exploratories as affected by forest management. $14^{\text {th }}$ Assembly of the Biodiversity Exploratories, Wernigerode, Germany (21-24 Feb 2017)

Nguyen DQ, Pena R, Polle A (2016) Ammonium and nitrate uptake of beech progenies from the Exploratories as affected by ectomycorrhizal diversity. $13^{\text {th }}$ Assembly of the Biodiversity Exploratories, Wernigerode, Germany (16-19 Feb 2016)

Nguyen DQ, Pena R, Polle A (2015) Beech performance and nitrogen uptake in response to soil fungal inoculation. GFÖ 2015: Ecology for a sustainable future, Göttingen, Germany (31 Aug-4 Sep 2015)

Nguyen DQ, Ammerschubert S, Pena R, Polle A (2015) Performance of beech as affected by soil fungi. $12^{\text {th }}$ Assembly of the Biodiversity Exploratories, Wernigerode, Germany (17-20 Feb 2015) 


\section{Curriculum vitae}

\section{Personal information}

Surname

First name

Date of birth

Place of birth

Address
Nguyen

Quang Dung

September $19^{\text {th }}, 1980$

Hanoi, Vietnam

Dac So, Hoai Duc, Hanoi, Vietnam

\section{Education and Work Experience}

Mar 2014 - present Doctoral student in Molecular Sciences and Biotechnology of Crops and Trees at Forest Botany and Tree Physiology, University of Göttingen, Germany. Title of thesis: Diversity and function of root-associated fungal communities in relation to nitrogen nutrition in temperate forests.

Jun 2012-Mar 2014

Work as a researcher at Vietnamese Academy of Forest Sciences, Hanoi, Vietnam

Mar 2010-Jun 2012

Master student in Biological Sciences and Biotechnology at Murdoch University, Western Australia, Australia. Title of the thesis: Hysterangium mats and associated bacteria under Eucalyptus gomphocephala in south-western Australia

Sept 2005-Mar 2010 Work as researcher at Vietnamese Academy of Forest Sciences, Hanoi, Vietnam

July 1999-June $2003 \quad$ Bachelor student in Forestry at Vietnam National University of Forestry, Hanoi, Vietnam 


\section{Acknowledgments}

I would like to express my deepest thanks to my principal supervisor Prof. Dr. Andrea Polle for allowing me to work in this interesting research topic and project and for her excellent supervision whenever I need. I am grateful to Prof. Dr. Konstantin V. Krutovsky and Prof. Dr. Ivo Feussner for giving me scientific advice on my PhD studies during my three thesis committee meetings.

I want to thank my colleagues at Department of Forest Botany and Tree Physiology for their support and encouragement during my PhD studies. Firstly, I would like to thank Kristina Schröter for collecting the beech nuts. I thank Dr. Rodica Pena for her great help and support throughout my PhD studies, especially with setting up the ${ }^{15} \mathrm{~N}$ labeling experiment and useful advice on presentation techniques and on critically understanding scientific papers during literature review courses. I am grateful to Dr. Dennis Janz for his excellent support with statistics and bioinformatics. I thank Dr. Nicole Brinkmann for her advice on my molecular work and finalizing my PhD studies. I would like to thank Silke Ammerschubert for her advice on both work and life and for all we experienced together with field harvests. I would like to thank Dr. Bettina Otto, Dr. Mareike Kavka, Dr. Dejuan Euring, Dr. Nan Yang, Dr. Nguyen Ngoc Quynh, Dr. Abdallah Awad, Dr. Aljosa Javisic, Dr Shanty Paul, Dade Yu, Gerrit-Jan Strijkstra, Johannes Ballauff, Simon Clausing, Carmen Alicia Rivera Pérez for nice discussions and support. I would also like to thank Thomas Klein, Gisbert Langer-Kettner, Merle Fastenrath, Monika Franke-Klein, Bernd Kopka, Gabriele Lehmann for their great technical support throughout my PhD studies.

I would like to thank Vietnamese government for providing me with a scholarship to study my $\mathrm{PhD}$ at University of Göttingen, Germany. I thank Forest Protection Research Centre and Vietnamese Academy of Forest Sciences for allowing me to study my PhD in Germany. I am grateful to Georg-August University School of Science (GAUSS) for granting me a GAUSS family oriented bridging grant. I thank German Research Foundation for funding this project as part of the DFG Priority Program 1374 "Infrastructure-Biodiversity-Exploratories" (DFG- PO362/18-3). This thesis would not have been possible without the support of a variety of people in the Biodiversity and Exploratories. I thank the managers of the three Exploratories, Kirsten Reichel-Jung, Swen Renner, Katrin Hartwich, Sonja Gockel, Kerstin Wiesner, and Martin Gorke for their work in maintaining the plot and project infrastructure; Christiane Fischer and Simone Pfeiffer for giving support through the 
central office, Michael Owonibi for managing the central data base, and Markus Fischer Karl Eduard Linsenmair, Dominik Hessenmöller, Jens Nieschulze, Daniel Prati, Ingo Schöning, François Buscot, Ernst-Detlef Schulze, Wolfgang W. Weisser and the late Elisabeth Kalko for their role in setting up the Biodiversity Exploratories project. Field work permits were issued by the responsible state environmental offices of Baden-Württemberg, Thüringen, and Brandenburg (according to $\S 72$ BbgNatSchG).

Last but not least, my deepest gratitude goes to my whole big lovely family, especially my wife, Dao Thi Hoa Hong for her support, encouragement, patient and love and to my beloved daughter, Nguyen Dao Thao Nhi. 


\section{Declaration of originality and certificate of authorship}

I, Quang Dung Nguyen, hereby declare that I am the sole author of this dissertation entitled "Diversity and function of root-associated fungal communities in relation to nitrogen nutrition in temperate forests". This work has not previously been submitted for a degree at any tertiary education institutions. To the best of my knowledge, all references and data sources that were used in this dissertation have been appropriately acknowledged.

Place/Date

Quang Dung Nguyen 